\title{
Electroreforming of Biomass for Value-Added Products
}

\author{
Zi Iun Lai ${ }^{1,+}$, Li Quan Lee ${ }^{1,2,+}$ and Hong Li 1,3,4,*(D) \\ 1 School of Mechanical and Aerospace Engineering, Nanyang Technological University, Singapore 639798, \\ Singapore; ZLAI005@e.ntu.edu.sg (Z.I.L.); LIQUAN001@e.ntu.edu.sg (L.Q.L.) \\ 2 Advanced Environmental Biotechnology Centre, Nanyang Environment and Water Research Institute, \\ Nanyang Technological University, 1 Cleantech Loop, Singapore 637141, Singapore \\ 3 School of Electrical and Electronic Engineering, Nanyang Technological University, Singapore 639798, \\ Singapore \\ 4 CINTRA CNRS/NTU/THALES, UMI 3288, Research Techno Plaza, Singapore 637553, Singapore \\ * Correspondence: ehongli@ntu.edu.sg \\ + These authors have equal contribution.
}

Citation: Lai, Z.I.; Lee, L.Q.; Li, H. Electroreforming of Biomass for Value-Added Products. Micromachines 2021, 12, 1405. https://doi.org/ $10.3390 / \operatorname{mi1} 2111405$

Academic Editor: Mehmet Remzi Dokmeci

Received: 20 October 2021

Accepted: 11 November 2021

Published: 16 November 2021

Publisher's Note: MDPI stays neutral with regard to jurisdictional claims in published maps and institutional affiliations.

Copyright: (C) 2021 by the authors Licensee MDPI, Basel, Switzerland. This article is an open access article distributed under the terms and conditions of the Creative Commons Attribution (CC BY) license (https:// creativecommons.org/licenses/by/ $4.0 /)$.

\begin{abstract}
Humanity's overreliance on fossil fuels for chemical and energy production has resulted in uncontrollable carbon emissions that have warranted widespread concern regarding global warming. To address this issue, there is a growing body of research on renewable resources such as biomass, of which cellulose is the most abundant type. In particular, the electrochemical reforming of biomass is especially promising, as it allows greater control over valorization processes and requires milder conditions. Driven by renewable electricity, electroreforming of biomass can be green and sustainable. Moreover, green hydrogen generation can be coupled to anodic biomass electroforming, which has attracted ever-increasing attention. The following review is a summary of recent developments related to electroreforming cellulose and its derivatives (glucose, hydroxymethylfurfural, levulinic acid). The electroreforming of biomass can be achieved on the anode of an electrochemical cell through electrooxidation, as well as on the cathode through electroreduction. Recent advances in the anodic electroreforming of cellulose and cellulose-derived glucose and 5-hydrooxylmethoylfurural (5-HMF) are first summarized. Then, the key achievements in the cathodic electroreforming of cellulose and cellulose-derived 5-HMF and levulinic acid are discussed. Afterward, the emerging research focusing on coupling hydrogen evolution with anodic biomass reforming for the cogeneration of green hydrogen fuel and value-added chemicals is reviewed. The final chapter of this paper provides our perspective on the challenges and future research directions of biomass electroreforming.
\end{abstract}

Keywords: biomass electroreforming; electrooxidation; electrochemical hydrogenation; cellulose; green hydrogen

\section{Introduction}

Climate change is arguably humanity's greatest challenge today. In 2019, an Intergovernmental Panel on Climate Change (IPCC) special report established several conditions required to restrict global temperature rise to $1.5^{\circ} \mathrm{C}$ above pre-industrial levels. By 2030, carbon emissions would need to be halved, and by 2050, the net carbon released into the atmosphere must be zero [1]. Worryingly, according to IPCC's 6th assessment report [2], Earth is perilously close to breaching the $1.5^{\circ} \mathrm{C}$ goal by 2030. Limiting temperature rise will require extensive effort, but inaction could result in sea level rise of $180 \mathrm{~cm}$ by 2100 , resulting in damages to the tune of USD 27 trillion per year [3]. With additional temperature rise, considerable increases in heat-related mortality can be expected, with warmer and poorer regions experiencing a disproportionate burden [4]. Consequently, water stress and food shortages could increase in frequency and severity $[5,6]$. The window for intervening is open but rapidly dwindling [7].

Replacing the burning of fossil fuels as our main energy source will be crucial. The solid and gaseous wastes humankind produces from the consumption of plants (biomass) 
go into the environment as carbon. The carbon in the air and soil is utilized by plants and turned into biomass and fuel. In this carbon cycle, biomass provides a renewable fuel. The utilization of such biodegradable waste can produce fuel resources and energy which does not result in as much carbon emissions as burning fossil fuel does. The annual biomass production in nature is estimated to be equivalent to 108 billion tons of oil, which is about ten times the world's energy consumption [8,9]. With a potential 200 billion tons of yield yearly, lignocellulosic biomass is the most abundant kind of natural biomass [10]. It consists primarily of cellulose, which constitutes between $30 \%$ and $50 \%$ of lignocellulosic biomass [11-13]. Cellulose is a crystalline biopolymer, constructed from long chains of D-glucose monomers, and has been isolated from plant matter and studied since the 17th century [14]. However, it was only in recent years that investigations into the valorization of cellulose feedstock became popular because of the growing awareness of green chemistry [15]. More importantly, cellulose is viewed as the significant feedstock component, as it does not compete with dietary sources, for example, edible crops for traditional biofuel production [16]. Methods to reform raw biomass, however, need to overcome cellulose's recalcitrance. Strong $\beta-1-4$-glycosidic linkages between glucose monomers lead to low reactivity, and the network of inter and intramolecular hydrogen bonding between long chains impedes dissolution in chemical solvents.

Several methods have been developed to break down cellulose, including hydrothermal processes [17], chemical hydrolysis [18], and biological treatments [19]. Hydrothermal processes generally use hot compressed water as the reaction medium to liquefy biomasses, and valuable products such as bio-oils are extracted through organic solvents [20]. Chemical catalysts are similarly employed to depolymerize cellulose, either in an acidic [21] or an alkaline medium [22]. Ethanol is the most common end product from biological treatments and is produced in two steps: cellulase enzymes initially catalyze the hydrolysis of cellulose into short chain sugars, which are then fermented into ethanol using yeasts or bacteria [23]. Each method has its unique benefits and drawbacks in terms of time required, capital costs, chemicals consumed, and control over quality and distribution of products [24,25].

Electrochemistry represents an effective tool in many important applications. For instance, in wastewater treatment by removal of organic pollutants or drugs (such as antibiotic waste tetracycline hydrochloride) from wastewater [26,27]. In addition, it also represents a promising tool in the valorization of cellulose thanks to its green and sustainable features, as illustrated in Figure 1. Through applying a potential difference across two electrodes, chemical reactions can be driven, with oxidation occurring at the anode (positive electrode) and reduction at the cathode (negative electrode). Two types of desired products-valorized chemicals on the anode and hydrogen gas on the cathode-can be obtained via cellulose electroreforming [28]. Depolymerization and oxidation of cellulose at the anode can produce valuable chemical products, which could reduce reliance on traditional fossil fuel-based and resource-intensive methods of production. Moreover, research on green hydrogen as a fuel source is receiving much attention because combusting hydrogen does not produce pollutants or greenhouse gases, and hydrogen has a high specific energy density $[29,30]$. Cellulose electroreforming requires catalysts, which can be homogeneous (dispersed in solution) or heterogeneous (often anchored on electrode). In most cases, the electrolyte is generated by dissolving cellulose in sodium hydroxide $(\mathrm{NaOH})$ via the freeze-thaw method first reported in 1998 [31]. Dissolution allows for greater access to active sites on $\beta-1-4$-glycosidic linkages [32]. When these linkages are fully broken, cellulose can be depolymerized into its monomer, glucose. 


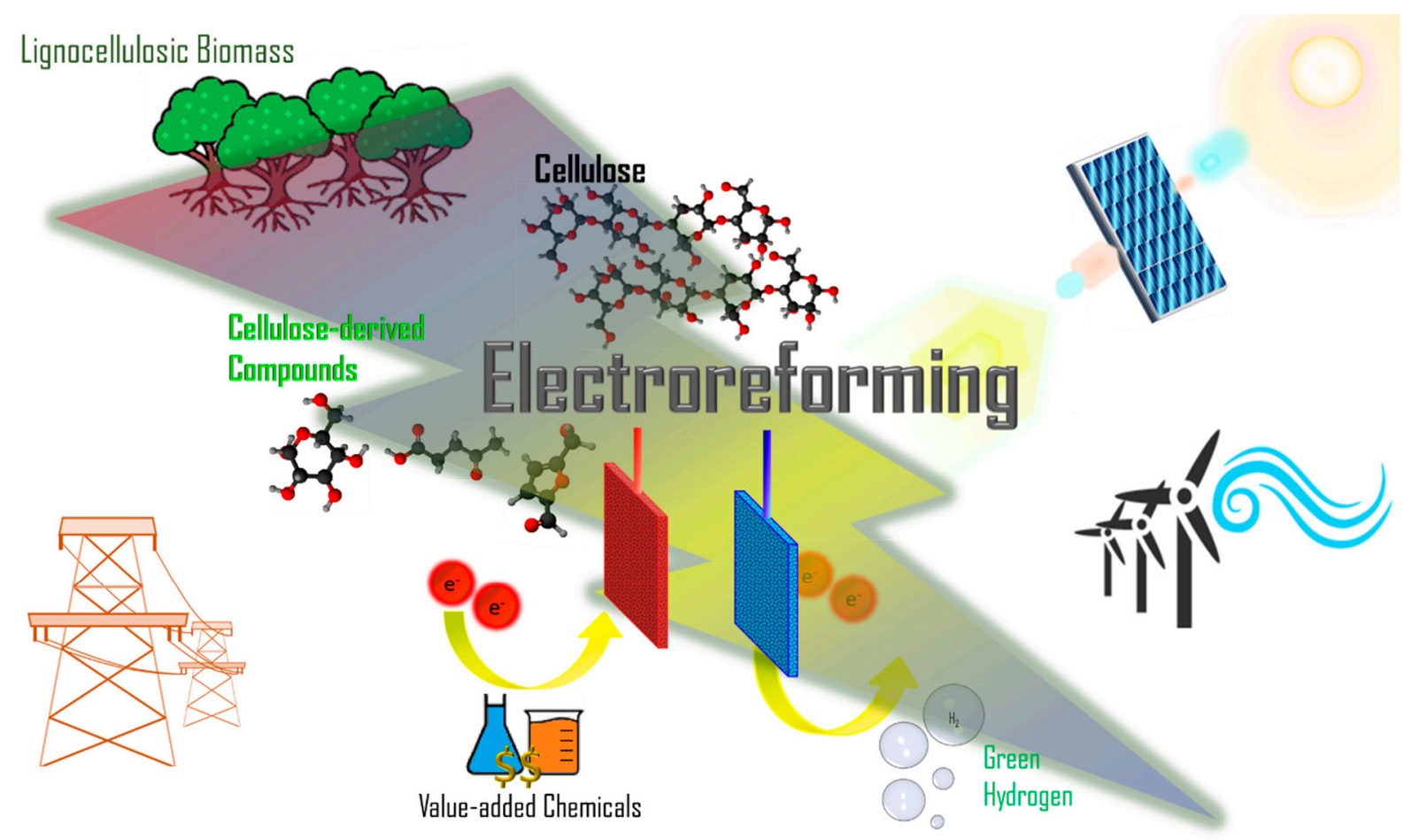

Figure 1. Schematic of biomass electroreforming. The most abundant lignocellulosic biomass is taken as an example. Electroreforming of the major component of lignocellulosic biomass, cellulose, or its derivatives, could offer value-added chemicals and green hydrogen fuel. Electroreforming can be powered by electricity from the grid or renewables, which makes it a promising method of renewable energy storage and green chemistry for a sustainable future.

Glucose is a simple monosaccharide with molecular formula $\mathrm{C}_{6} \mathrm{H}_{12} \mathrm{O}_{6}$, and is the main source of energy for most life forms on earth. Apart from cellulose, glucose can also be stored in other polymeric forms, such as starch in plants or glycogen in animals. Glucose can be electrochemically converted to gluconic, glucaric and levulinic acids, as well as 5-HMF. These products can be further valorized into other valuable compounds through electrochemical oxidation (anodic reaction) or hydrogenation (cathodic reaction). Some common glucose transformations are shown in Figure 2.

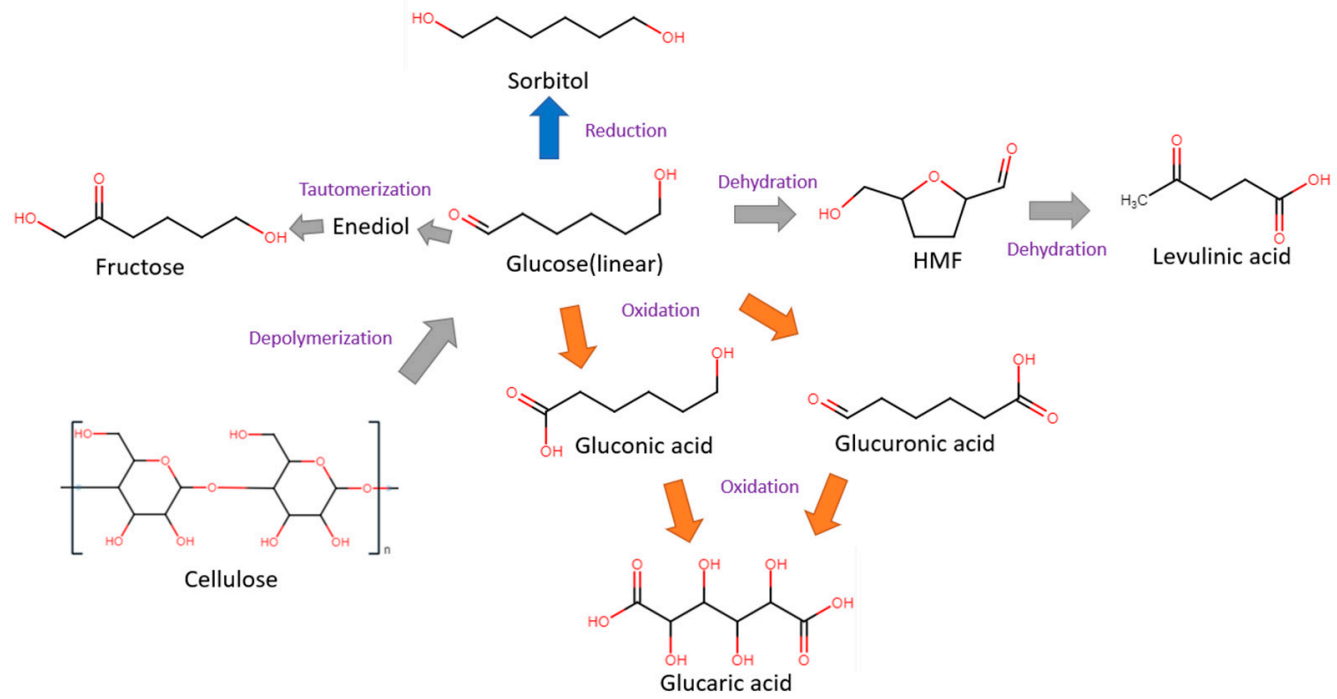

Figure 2. Cellulose, glucose and its derivatives. 
Herein, a mini review is presented to summarize the electroreforming of cellulose and its derivatives under different $\mathrm{pH}$ conditions using various catalysts. Depending on the targeted final products, the electroreforming of cellulose can be achieved via electrooxidation on the anode or electroreduction on the cathode. We will firstly discuss the recent advances in anodic electroreforming followed by cathodic electroreforming of cellulose and its derivatives. We will focus on the heterogenous catalysts employed and electroreformed products. Then, the emerging research interest on coupling hydrogen evolution (on cathode) with anodic biomass reforming is discussed. To conclude this mini review, our perspectives on the challenges and opportunity on biomass electroreforming are presented.

\section{Electroreforming of Biomass at the Anode}

\subsection{Cellulose}

Cellulose monomers comprise two anhydroglucose rings of $\mathrm{C}_{5} \mathrm{H}_{10} \mathrm{O}_{5}$. The rings share an ether (C-O-C) bond between carbon- 1 of a glucose ring and carbon- 4 of the other, also known as a $\beta-1-4$-glycosidic bond. Additionally, intramolecular hydrogen bonding between the hydroxyl group and oxygen on adjacent glucose rings straightens and stabilizes cellulose chains. Intermolecular hydrogen bonding between adjoining cellulose chains also promotes stability and forms crystalline structure [33]. Cellulose exists in four polymorphic varieties: I, II, III and VI. Cellulose I will be focused on here, since it is the natural cellulose found in plant matter, and can be used to form other polymorphs.

The earliest study passing electricity through cellulose was reported in 1947. O'Sullivan investigated passing current through regenerated cellulose with varying salt and moisture contents to understand the conductance properties of cellulose. In 1963, Murphy performed the first electrolysis of cellulose and observed that hydrogen gas was produced at the anode. However, studies of cellulose electrolysis remained relatively scarce and sporadic until the 21 st century, when ever-increasing demand for green and sustainable chemistry appeared.

In 2010, Sugano et al. performed electrooxidation of cellulose at a polycrystalline gold $(\mathrm{Au})$ electrode at a $\mathrm{pH}$ of 14 to understand its mechanism [34]. Cellulose powder was first dissolved in $\mathrm{NaOH}$ using the freeze-thaw technique, after which the cellulose's structure was no longer crystalline, suggesting the breakage of intra- and intermolecular hydrogen bonding, which is verified by both microscopic images and X-ray diffraction (XRD) spectroscopy, as presented in Figure 3a,b, respectively. Cyclic voltammetry (CV) revealed two oxidation peaks for dissolved cellulose but not for undissolved cellulose. To explore the effects of particle sizes, ball mill crushing was used to generate cellulose particles of two size ranges, 500 and $100 \mathrm{~nm}$, as shown in Figure 3c,d. Smaller particles led to $13 \%$ higher peak current at similar applied potentials, indicating that ball mill pretreatment was efficient in promoting the dissolution of cellulose. Fourier transform infrared imaging (FTIR) scans (Figure 3e) suggested the formation of carboxyl groups, confirming the oxidation of cellulose. To produce direct electricity from oxidation of cellulose nanoparticles, the fuel cell was created and could attain maximum power density of $44 \mathrm{~mW} / \mathrm{m}^{2}$. 
(a)

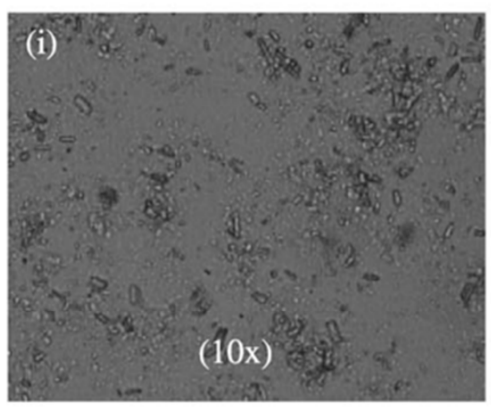

(d)

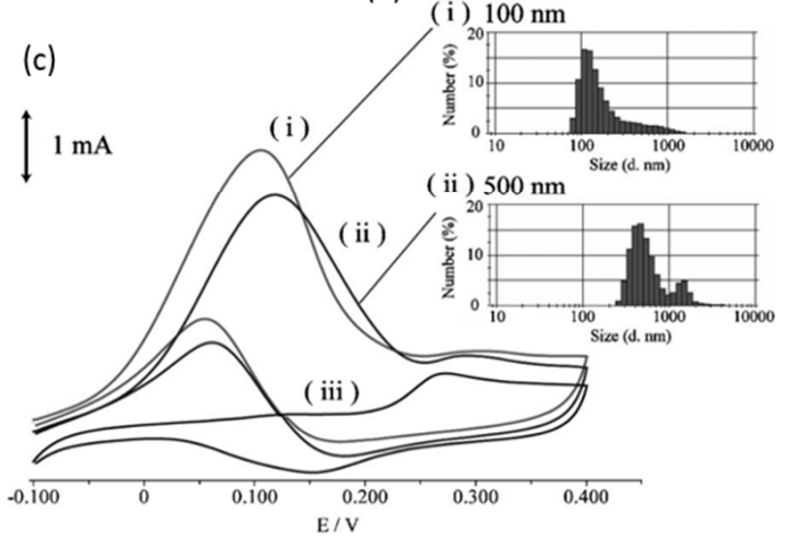

(b)

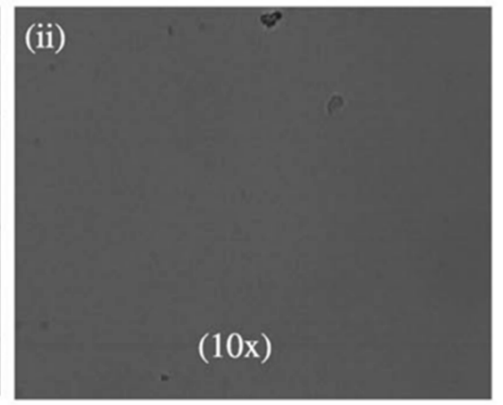

(i)

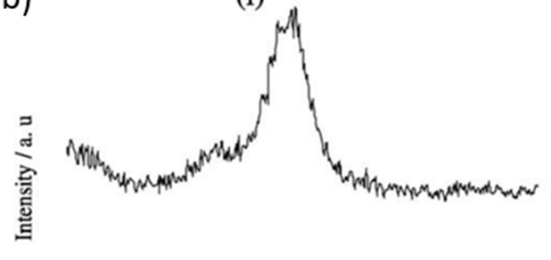

(ii)

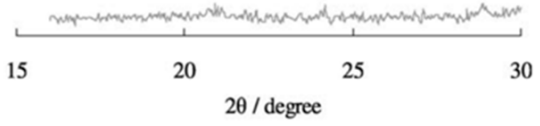

(e)

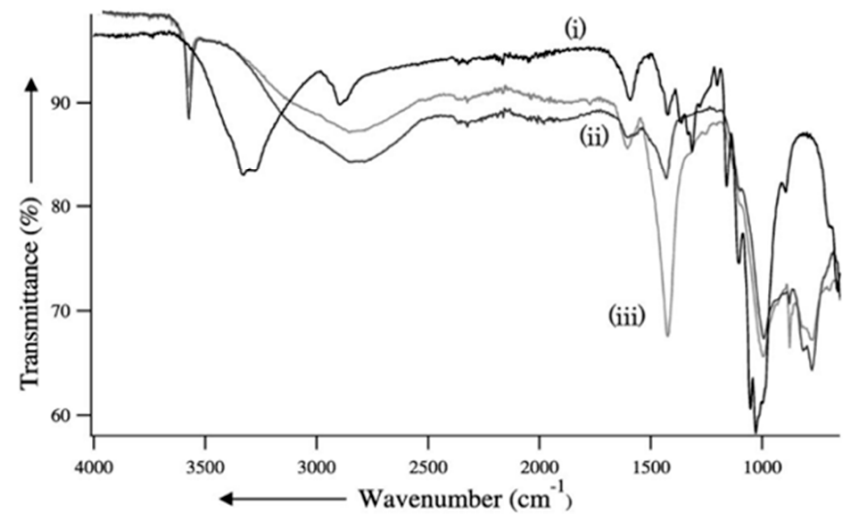

Figure 3. (a) Microscopic images before (i) and after (ii) dissolution. (b) X-ray diffraction of cellulose before (i) and after (ii) dissolution. (c) cyclic voltammogram (vs. $\mathrm{Ag} / \mathrm{AgCl}$ ) of cellulose ball milled to average particle size of $100 \mathrm{~nm}$ (i), $500 \mathrm{~nm}$ (ii) and without cellulose (iii). (d) size distribution after ball milling to $100 \mathrm{~nm}$ (i) and $500 \mathrm{~nm}$ (ii). (e) FTIR scans of cellulose before dissolution (i), after dissolution (ii) and after oxidation (iii). Reprinted with permission from Ref. [34]. Copyright 2010, Electroanalysis.

Later, their team studied the electroreforming mechanism in a similar alkaline medium [35]. CV scans suggested that cellulose electrooxidation is irreversible and diffusion-controlled. FTIR was conducted during CV to understand interactions between cellulose and the Au electrode, which suggests that the adsorbed cellulose displaces $\mathrm{OH}^{-}$ ions near the electrode surface; and during oxidation, the strength of intermolecular $\mathrm{H}$ bonds decreases while that of intramolecular bonds increases. The authors proposed the reaction pathway, as illustrated in Figure 4. Firstly, $\mathrm{OH}^{-}$ions adsorb onto the surface of gold electrodes to form $\mathrm{OH}-\mathrm{Au}$ sites. These active sites then allow cellulose to adhere electrochemically with Au electrode surface. Cellulose is oxidized and remains adsorbed until reversed potential is applied. The authors hypothesized that the adsorption and desorption of $\mathrm{OH}^{-}$ions play an important catalytic role in cellulose electrooxidation. Nuclear magnetic resonance (NMR) spectra and scanning electron microscope (SEM) imaging suggested the differences in the structure of cellulose after electroreforming; however, the exact products were not identified. 


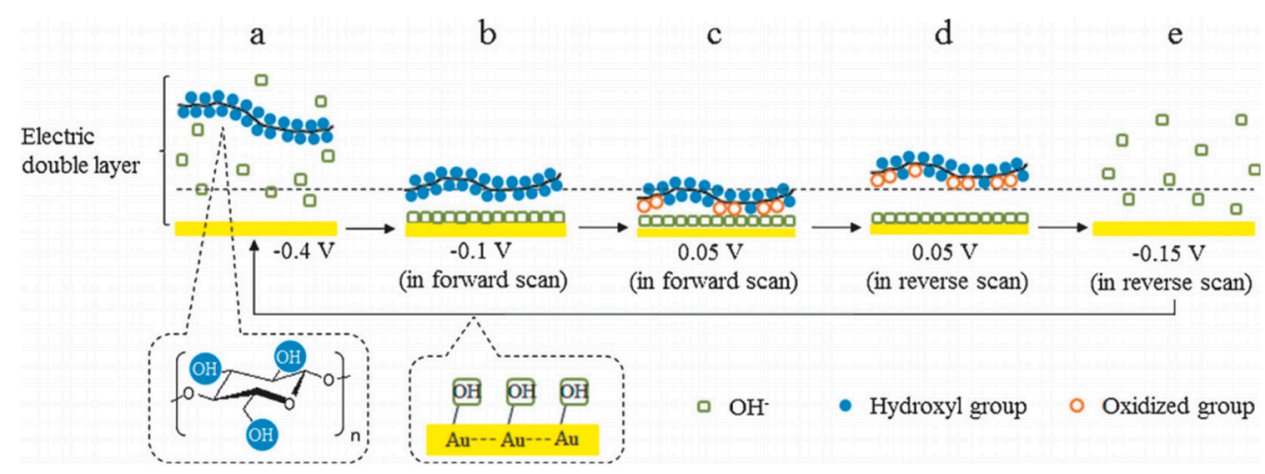

Figure 4. Proposed cellulose oxidation mechanism on electrode surface in alkali media in CV cycle. (a) initial state, with cellulose dissolved in alkali solution. (b) in forward scan region: adsorption of $\mathrm{OH}^{-}$ions to surface of electrode, cellulose molecule approaches $\mathrm{OH}-\mathrm{Au}$ active sites. (c) oxidation of cellulose at electrode. (d) in reverse scan region: desorption of oxidation product and further oxidation of cellulose at revealed electrode surface. (e) desorption of $\mathrm{OH}^{-}$ions from electrode surface. Reprinted with permission from Ref. [35]. Copyright 2014, ChemSusChem.

A notable investigation was conducted in 2016, when Xiao and coworkers reported the use of gold nanoparticles (AuNP) for cellulose electroreforming [36]. Motivated by similar works on cellobiose [37,38], the authors explored the use of nitric acid $\left(\mathrm{HNO}_{3}\right)$-pretreated carbon aerogel with AuNP as an anode, as shown in Figure 5. Carbon aerogel was fabricated as per a previous report [39], before acid pretreatment. A mixture containing Au precipitates was prepared by reacting $\mathrm{HAuCl}_{4}$ and $\mathrm{NaB}_{4}$ [40]. Deposition of AuNP onto carbon aerogel was performed by repeatedly dipping aerogel into the mixture and drying it. The anode was used to oxidize cellulose in $0.125 \mathrm{M} \mathrm{NaOH}$ ( $\mathrm{pH}$ of 13.1) with insufflated air. Introduction of oxygen was proposed to speed up the formation of active oxygen species to accelerate oxidation. The authors compared three anodes to study the activities of AuNP with different sizes: $50 \mathrm{~nm}$ gold particles on graphite, $50 \mathrm{~nm}$ gold particles on carbon aerogel, and 10 nm gold particles on carbon aerogel, as shown in Figure 5a-c. AuNP sizes were calculated from XRD data (Figure 5d) and supported by SEM measurements. Cellulose oxidation was controlled at $10 \mathrm{~mA} / \mathrm{cm}^{2}$ and products were evaluated with high-performance liquid chromatography (HPLC), as presented in Figure 5e.
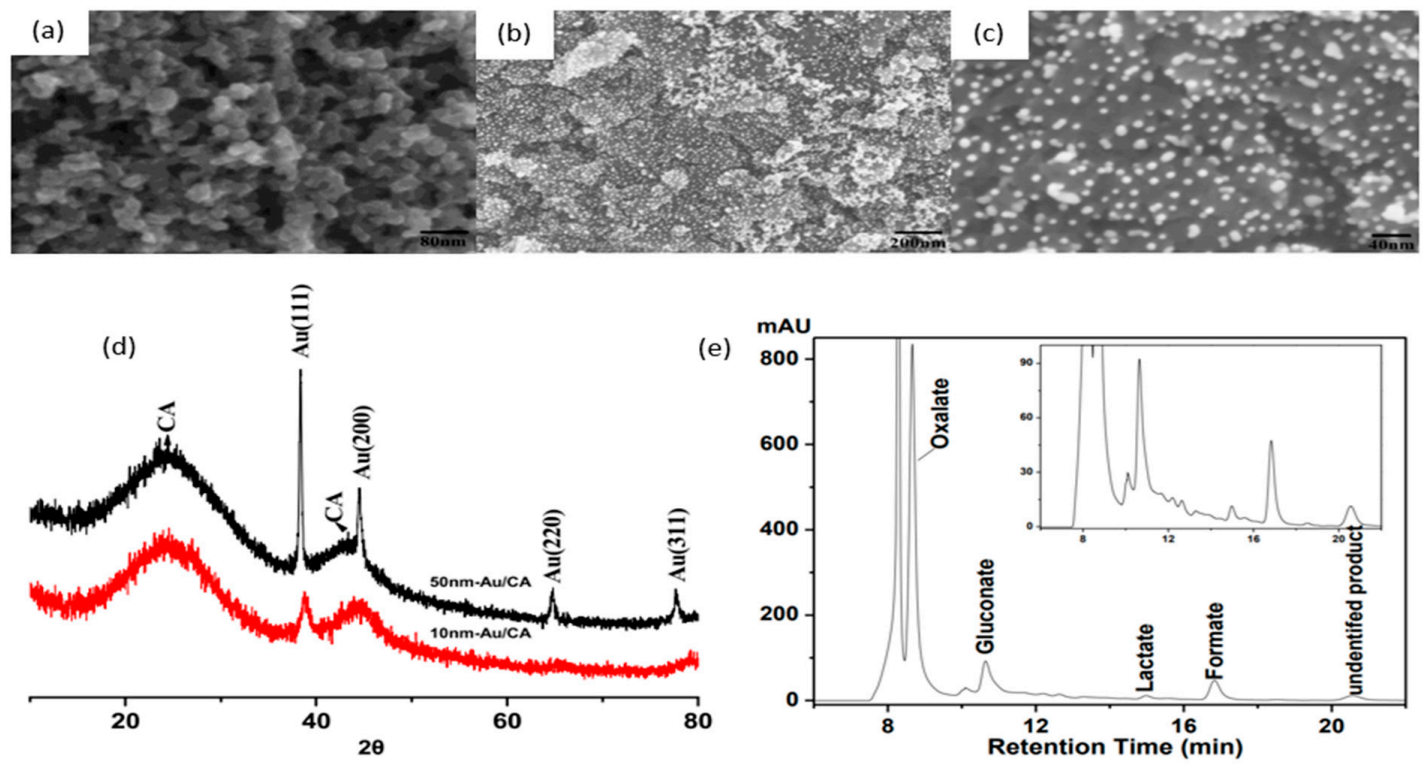

Figure 5. (a) SEM image of pretreated CA. (b) SEM of $10 \mathrm{~nm}$ Au/CA. (c) Magnified SEM of $10 \mathrm{~nm}$ Au/CA. (d) XRD results of $10 \mathrm{~nm} \mathrm{Au} / \mathrm{CA}$ and $50 \mathrm{~nm}$ Au/CA electrodes. (e) High performance liquid chromatography results of products using 10 $\mathrm{nm} \mathrm{Au} / \mathrm{CA}$ electrodes. Reprinted with permission from Ref. [36]. Copyright 2015, Catalysis. 
Comparing anodes consisting of 10 and $50 \mathrm{~nm}$ AuNP on the same supporting substrate (CA), one can see that the $50 \mathrm{~nm} \mathrm{NP}$ anode also obtained high cellulose conversion, but selectivity towards gluconate was significantly lower, suggesting that the size of AuNP influences the selectivity of oxidation products. Reducing aeration did not change oxidation products but decreased the rate of reaction. Ten-nanometer gold particles on acid-pretreated carbon aerogel produced gluconic acid at a $67.8 \%$ yield with a conversion yield of at least $88.9 \%$.

When comparing anodes with the same $10 \mathrm{~nm}$ gold particles on different supporting substrates, the pretreated carbon aerogel supports resulted in better cellulose conversion than that of graphite support. The authors hypothesized that acid pretreatment of CA led to a higher surface area and oxidized surface carbon, favoring the adsorption of cellulose molecules.

Sugano et al. also attempted to understand cellulose electroreforming mechanism using AuNPs, again in alkaline ( $\mathrm{pH}$ of 14) conditions [41]. Carbon paper supports were loaded with AuNPs through the chemical precipitation-deposition method. The electrodes were then calcinated at different temperatures $\left(40,250\right.$, and $\left.350{ }^{\circ} \mathrm{C}\right)$. The author observed that calcination at $40{ }^{\circ} \mathrm{C}$ led to the formation of $\mathrm{Au}^{+}(52.5 \%)$ and $\mathrm{Au}^{3+}(30 \%)$, while calcinations at higher temperature led to completely metallic AuNPs. Moreover, calcination at $250^{\circ} \mathrm{C}$ produced AuNPs with sizes ranging in a narrow band $(10-25 \mathrm{~nm})$, whereas a further increased temperature of $350^{\circ} \mathrm{C}$ resulted in larger clusters $(20-30 \mathrm{~nm})$. CVs were conducted with $1.3 \mathrm{M} \mathrm{NaOH}$ against a $\mathrm{Ag} / \mathrm{AgCl}$ reference, with and without $(1 \mathrm{wt} \%)$ cellulose present. Anode calcinated at $40^{\circ} \mathrm{C}$ displayed no electrocatalytic activity. Moreover, the anode calcinated at $350^{\circ} \mathrm{C}$ shows lower electrocatalytic activity than the anode calcinated at $250{ }^{\circ} \mathrm{C}$, indicating that small AuNPs $(<25 \mathrm{~nm})$ have higher activity.

Meng et al. electrolyzed cellulose powder in $0.5 \mathrm{M}$ sulfuric acid ( $\mathrm{pH}$ of 0.3 ), rather than in alkali solution, using lead/lead dioxide $\left(\mathrm{Pb} / \mathrm{PbO}_{2}\right)$ electrodes [42], as depicted in Figure 6a. Under ambient conditions, with a controlled current density of $30 \mathrm{~mA} / \mathrm{cm}^{2}$ for $8 \mathrm{~h}$, the degree of polymerization (DP) at average decreased from 1100 to 367. Conversely, the sample that was exposed only to acid had a final DP of 840, as displayed in Figure $6 \mathrm{~b}, \mathrm{c}$. XRD measurement showed a reduced degree of crystallinity, while FTIR showed lower intensities associated with $\mathrm{H}$ and $\mathrm{C}-\mathrm{O}-\mathrm{C}$ bonds without the formation of new groups. A maximum soluble sugar content yield of $2.5 \%$ and the highest 5-HMF yield of $1.8 \%$ were obtained.

(a)

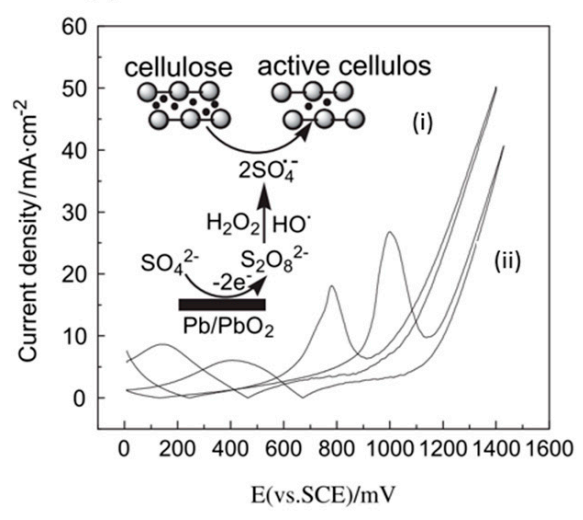

(b)

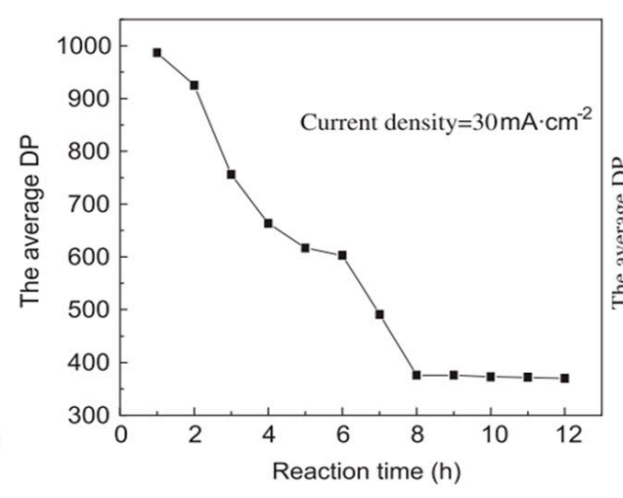

(c)

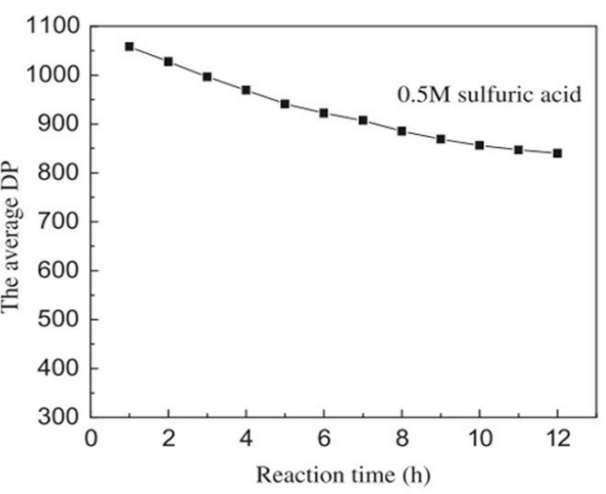

Figure 6. (a) CVs (vs. SCE) of 0.5 M sulfuric acid (i) and $0.5 \mathrm{M}$ sulfuric acid with $10 \mathrm{~g} / \mathrm{L}$ cellulose (ii). (b) Decrease in DP over time at $30 \mathrm{~mA} / \mathrm{cm}^{2}$. (c) Decrease in DP over time without applied current. Reprinted with permission from Ref. [42]. Copyright 2011, Polymer Degradation and Stability.

Meng and coworkers proposed an electrocatalytic depolymerization process, as presented in Figure 7. Firstly, water molecules lose electrons at the anode to form hydroxyl radicals $\left(\mathrm{OH}^{-}\right)$. Next, the $\mathrm{OH}^{-}$attacks the $\mathrm{C}-\mathrm{H}$ bond and removes the hydrogen atom from carbon-4 of the glucose unit, leaving a carbon radical $\left(\mathrm{C}^{-}\right)$in cellulose. $\mathrm{C}^{-}$is then oxidized 
to become a superoxide radical $\left(\mathrm{O}_{2}^{-}\right)$. Finally, the glycosidic bond is cleaved through the removal of the superoxide radical.
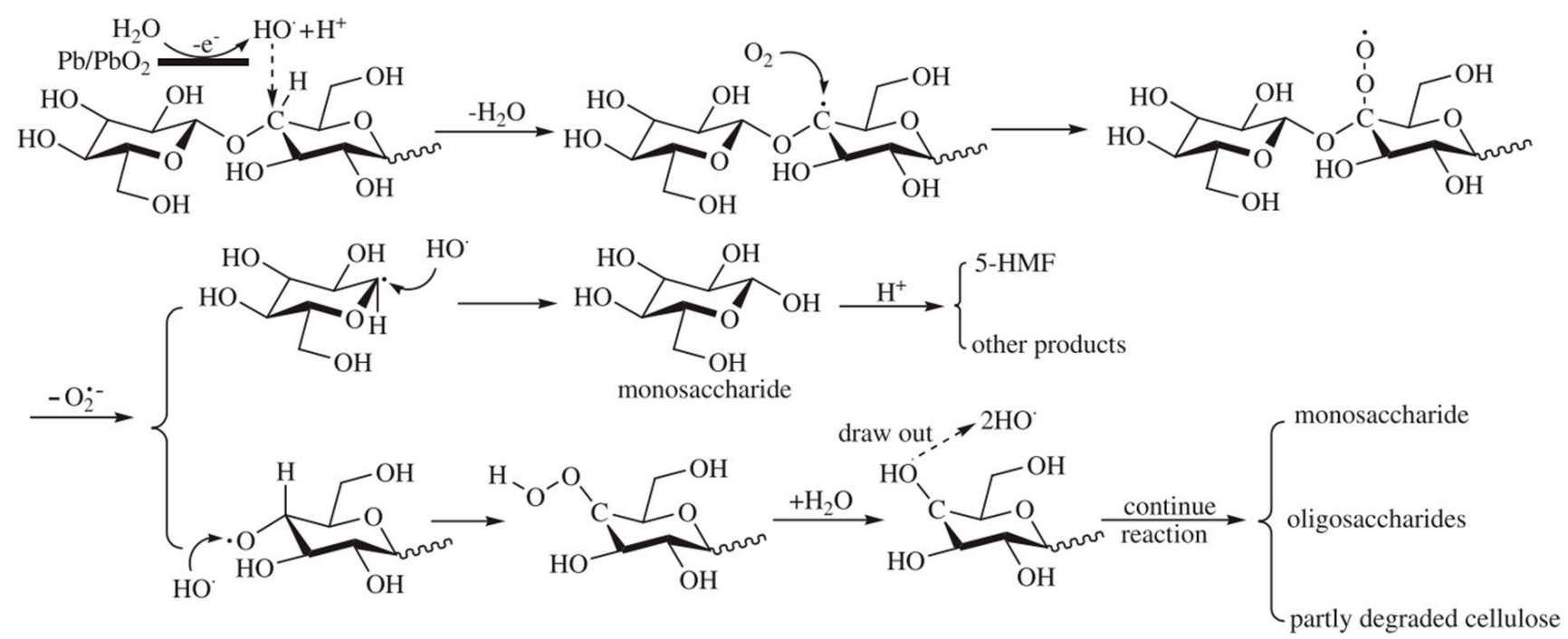

Figure 7. Proposed cellulose depolymerization mechanism in acidic media. Reprinted with permission from Ref. [42]. Copyright 2011, Polymer Degradation and Stability.

\subsection{Glucose}

Glucose is the most abundant monosaccharide on Earth [43]. Electrolysis of glucose was reported as early as 1866 to produce acetaldehyde; early reports also speculated on the possible formation of alcohol and many other substances [44]. Indeed, studies have revealed a variety of useful products from glucose electroreforming, including 5-HMF, gluconic acid, glucaric acid, gluconolactone and levulinic acid, among others. The synthesis of glucaric acid in particular has been widely acknowledged for its high value. With applications in many industries, glucaric acid has being listed as one of the most valueadded chemicals by the US Department of Energy [45-47]. However, conventional methods for glucaric acid production often require intense pressures, temperatures and harsh chemicals [48]. Gluconic acid is an intermediate towards the production of glucaric acid, and by itself has other commercial applications [49,50]. Levulinic acid and 5-HMF are platform compounds for producing other useful chemicals [51-53].

In 2014, Bin et al. optimized conversion of glucose to glucaric and gluconic acids with nano-manganese dioxide $\left(\mathrm{MnO}_{2}\right)$ loaded tubular porous titanium (Ti) electrodes in a flow-through electrolytic cell, as shown in Figure 8a,b [54]. Interestingly, unlike most other studies, $\mathrm{pH}$ was concluded to be less significant in this case-increasing $\mathrm{pH}$ from 2 to 10 only changed glucose conversion slightly, from $90 \%$ to $93 \%$. Selectivity to gluconic acid (GLA) and glucaric acid (GA) rose from $87 \%$ at a $\mathrm{pH}$ of 2 to a maximum of $94 \%$ at a $\mathrm{pH}$ of 7 , before decreasing to $78 \%$ at $\mathrm{pH} 10$. The flow-through cell (Figure $8 \mathrm{~b}$ ) was believed to limit the expansion of the electrochemical diffusion layer and promote glucose access to anode surface by convection. The effects of current density on glucose conversion to product selectivity were also studied (Figure 8c). With $\mathrm{MnO}_{2}$ loading of $4.98 \%$, glucose concentration of $50.5 \mathrm{mM}$, temperature of $30^{\circ} \mathrm{C}, \mathrm{pH}$ of 7 , residence time of $19 \mathrm{~min}$, and current density of $4 \mathrm{~mA} / \mathrm{cm}^{2}, 98 \%$ glucose conversion was achieved with selectivity towards gluconic acid and glucaric acid of $43 \%$ and $55 \%$, respectively. Increasing current density to $6 \mathrm{~mA} / \mathrm{cm}^{2}$ further led to $99 \%$ glucose conversion, with gluconic and glucaric selectivities of $15 \%$ and $84 \%$, respectively. 

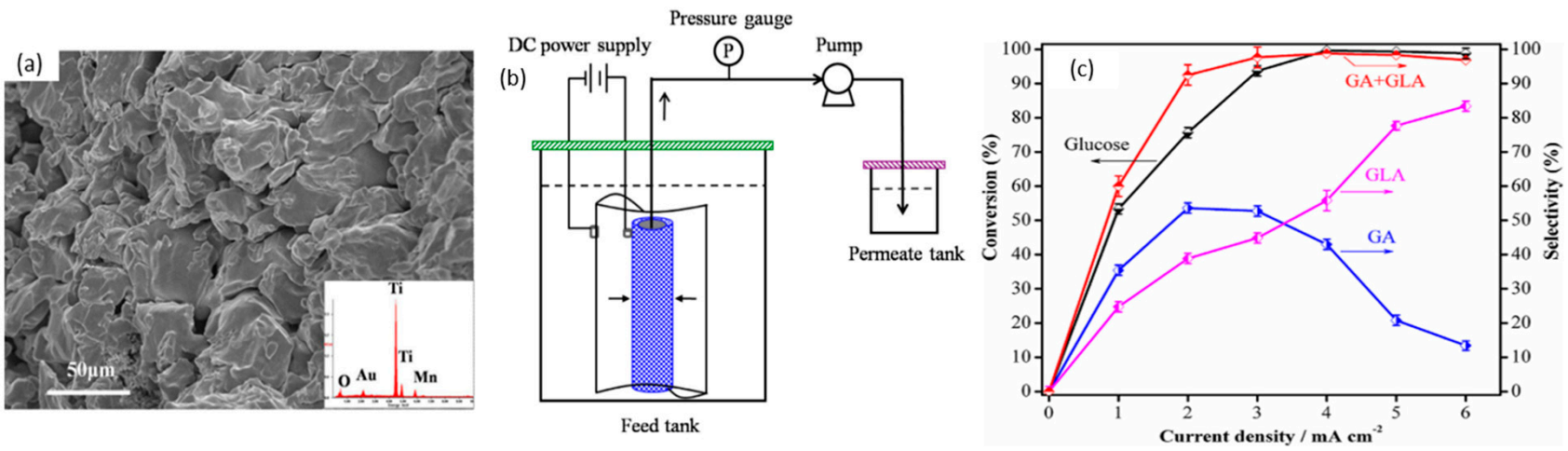

Figure 8. Nano $\mathrm{MnO}_{2}$ / Ti electrocatalysts in flow-through cells for glucaric acid (GA) and gluconic acid (GLA) production from glucose. (a) SEM image of $5 \% \mathrm{MnO}_{2} / \mathrm{Ti}$ electrode. (b) Schematic diagram of electrocatalytic flow reactor system. (c) Products at different current densities (under $5 \% \mathrm{MnO}_{2}$ loading, glucose concentration of $50.5 \mathrm{mmol} / \mathrm{L}, \mathrm{pH}$ of $7,30{ }^{\circ} \mathrm{C}$, 19 min). Reprinted with permission from Ref. [54]. Copyright 2014, Electrochimica Acta.

In 2017, Solmi et al. investigated the effects of varying ratios of different reactants (glucose to $\mathrm{NaOH}$, glucose to metal catalyst, and glucose concentration levels), temperature and pressure, on glucose conversion to glucaric acid [55]. Under optimal conditions using AuNPs on activated carbon support, the highest yields of glucaric acid, gluconic acid and other by-products attained were $31 \%, 18 \%$ and $40 \%$, respectively. The authors proposed that the optimal glucose concentration was $5 \%$ and that the molar ratio of glucose to metal should be 500:1 for obtaining glucaric acid.

Moggia et al. compared electrooxidative performance of bare copper $(\mathrm{Cu})$, platinum $(\mathrm{Pt})$ and $\mathrm{Au}$ at varying potentials for different functional groups [56]. The researchers first compared CVs of $0.04 \mathrm{M}$ glucose added to $0.1 \mathrm{M}$ sodium hydroxide with $\mathrm{Cu}, \mathrm{Pt}$ and $\mathrm{Au}$ electrodes, and concluded that glucose oxidation is strongly correlated with metal catalysts. Next, gluconic acid, glucuronic acid and glucaric acid were used to identify if different functional groups are oxidized by metal catalysts. $\mathrm{Cu}$ was found to selectively oxidize glucose aldehyde group at $0.8-1.2$ V, but not the hydroxymethyl group. Pt oxidized hydroxymethyl groups at lower potentials and aldehyde groups at higher potentials, while $\mathrm{Au}$ oxidized hydroxymethyl at higher potentials and aldehydes at lower ones. Finally, to minimize competing side reactions (glucose isomerization and sugar degradation [57]) the authors performed glucose electroreforming at $5{ }^{\circ} \mathrm{C}$ at $\mathrm{pH} 13$ for all three metal catalysts. Although good selectivity to glucaric acid was observed at lower potential $(38.4 \%$ at $0.86 \mathrm{~V})$, current densities with $\mathrm{Cu}$ were too low. Increasing potentials resulted in formic acid as the major product. Pt and Au exhibited similar catalytic action: at low potentials $(0.55-0.70 \mathrm{~V})$, both exhibited high selectivity to gluconic acid (78.4-86.8\%). Increasing potential to $1.34 \mathrm{~V}$ for $\mathrm{Pt}$ and prolonged electrolysis at $0.70 \mathrm{~V}$ for Au produced glucaric acid selectivities of $13.5 \%$ and $12.6 \%$, respectively.

Moggia and co-workers then went on to optimize conditions for each of the two oxidation steps at $\mathrm{Au}$ anodes: (1) glucose to gluconic acid, and (2) gluconic acid to glucaric acid [58]. For the first step, $\mathrm{pH}$, glucose concentration, and temperature were all found to influence conversion. Optimal parameters of $\mathrm{pH}$ of 11.3 , glucose concentration of $0.04 \mathrm{M}$, temperature of $5{ }^{\circ} \mathrm{C}$ and potential of $0.6 \mathrm{~V}$ resulted in the highest gluconic acid selectivity of $97.6 \%$, with glucose conversion of $25 \%$ across a $6 \mathrm{~h}$ reaction. Increasing conversion by elevating $\mathrm{pH}$ or temperature produced lower selectivity. Increasing glucose concentration likely affected mass transfer to Au active sites, which also reduced selectivity. On the other hand, none of the above parameters were significant for oxidizing gluconic acid to glucaric acid. Instead, applied potential considerably influenced the product distribution. As illustrated, the maximum selectivity of $89.5 \%$ was attained at $1.1 \mathrm{~V}$ vs. RHE. Unfortunately, gluconic acid conversion was low (4.6\%). Nevertheless, the highest possible glucaric acid concentration obtained was $1.2 \mathrm{mM}$. Furthermore, the drastic drop in current density was 
observed after a few hours, likely due to the adsorption of glucaric acids at Au active sites, as reported previously [59].

Liu et al. used both nanostructured bimetallic nickel-iron oxide $\left(\mathrm{NiFeO}_{\mathrm{x}}\right)$ and nitride $\left(\mathrm{NiFeN}_{\mathrm{x}}\right)$ electrodes for gluconic and glucaric acid production [60]. $\mathrm{NiFeO}_{\mathrm{x}}$ nickel foam (anode) was used in $0.5 \mathrm{M}$ glucose and $1 \mathrm{M}$ potassium hydroxide, while $\mathrm{NiFeN}_{\mathrm{x}}$ nickel foam was used as the cathode in $1 \mathrm{M} \mathrm{KOH}$. At a constant applied voltage of $1.4 \mathrm{~V}$, glucose conversion of $21.3 \%$ was attained, and glucaric acid and gluconic acid yields were $11.6 \%$ and $4.7 \%$, respectively. The Faradaic efficiencies for both glucaric and gluconic acids were $87 \%$. The current density at $1.4 \mathrm{~V}$ decreased from 101.2 to $97.8 \mathrm{~mA} / \mathrm{cm}^{2}$ over a $24 \mathrm{~h}$ run. The authors' technoeconomic analysis suggests that this method produces glucaric acid at $54 \%$ lower cost compared to conventional production methods.

In 2021, Neha et al. created platinum-bismuth alloy $\left(\mathrm{Pt}_{9}-\mathrm{Bi}_{1}\right)$ electrocatalyst on glassy carbon electrode for glucose conversion to gluconic acid, accompanied by methyl-glucoside conversion to methyl-glucuronate [61]. In an electrolyte consisting of $0.1 \mathrm{M} \mathrm{NaOH}(0.1 \mathrm{M}$ glucose added), linear sweep voltammetry (LSV) scans showed the onset voltage to be less than $0.06 \mathrm{~V}$ and a broad peak at $4.58 \mathrm{~mA} / \mathrm{cm}^{2}$ around 0.6 to $0.8 \mathrm{~V}$. Chronoamperometric measurement at a fixed potential of $0.3 \mathrm{~V}$ was conducted with $\mathrm{Pt}_{9}-\mathrm{Bi}_{1} / \mathrm{C}$ anode and $\mathrm{Pt} / \mathrm{C}$ cathode for $6 \mathrm{~h}$, in a filter press cell. After about $90 \mathrm{~min}$, the current halved $(\sim 0.020$ to $0.010 \mathrm{~A}$ ) and plateaued at around $0.005 \mathrm{~A}$. These readings suggest that some poisoning occurred. The product after a $6 \mathrm{~h}$ reaction was confirmed to be gluconate with $100 \%$ selectivity using HPLC and NMR, with $40 \%$ glucose conversion.

Poisoning of electrodes is a significant challenge in scaling up glucose electroreforming, suspected to be caused by the action of reaction intermediates [62]. In 2005, Tominaga et al. compared glucose electrooxidation between pure Au plate and AuNPs ( $2 \mathrm{~nm}$ in diameter) on carbon electrode [59], as shown in Figure 9a. While CV scans suggested a similar voltametric response, gold nanoparticle catalysts exhibited significantly smaller decreases in current over time, displaying better resistance to poisoning, as displayed in Figure $9 \mathrm{~b}$. The reduction in current density was mitigated by increasing $\mathrm{pH}$. Additionally, Tominaga et al. identified that high selectivity towards gluconate can be obtained at a high $\mathrm{pH}$ of 13.7, while electroreforming at neutral conditions ( $\mathrm{pH}$ of 7) produced a mixture of gluconate and oxalate. Similarly, applied potential can be another factor to influence products, as seen in Figure 9c. Most later studies have therefore focused on employing nanoparticle electrocatalysts in alkali media.
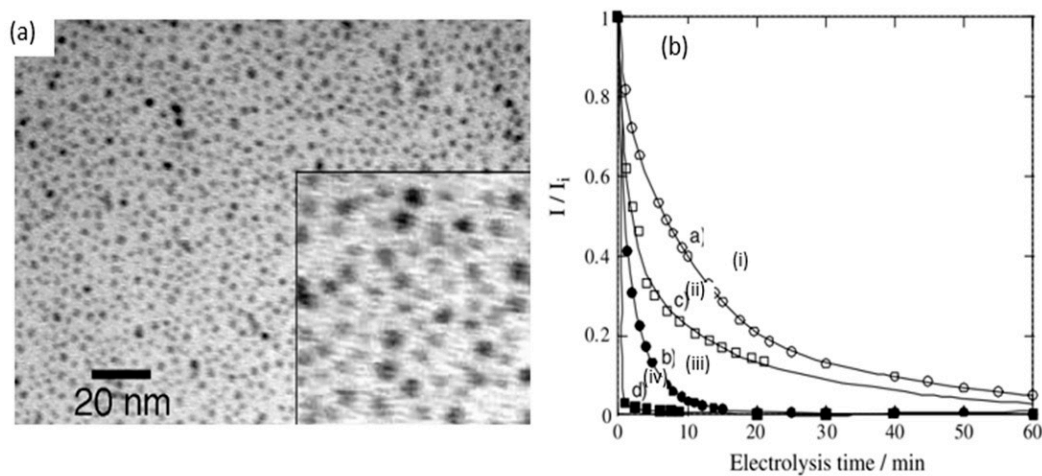

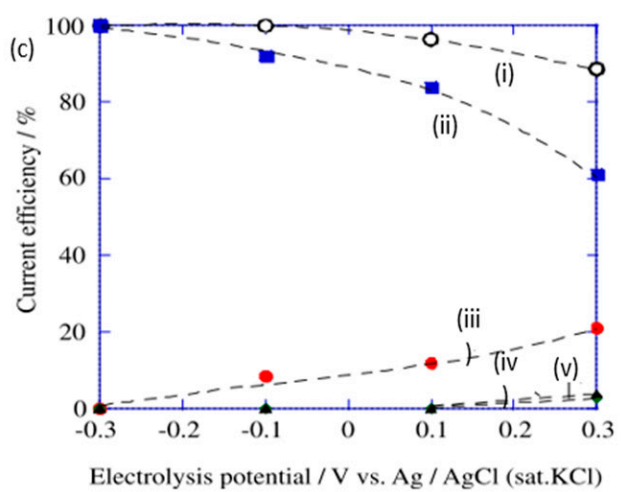

Figure 9. (a) TEM image of AuNP capped with decanethiolate monolayer shell (for deposition on electrode). (b) Change in current ratios across time with gold nanoparticles in alkali medium (i), bulk gold in alkali medium (ii), gold nanoparticles in neutral medium (iii), and bulk gold in neutral medium (iv). (c) Plots of electrolysis products with $2 \mathrm{~nm}$ AuNP in $0.1 \mathrm{M}$ $\mathrm{NaOH}, 0.01 \mathrm{M}$ glucose, at different potentials (vs. $\mathrm{Ag} / \mathrm{AgCl}$ ); total current efficiency of all products (i), gluconolactone (ii), oxalate (iii), glyconate (iv), formate (v). Reprinted with permission from Ref. [59]. Copyright 2005, Electrochemistry Communications. 


\subsection{5-Hydroxylmethylfurfural}

5-hydroxylmethylfurfural (5-HMF) was included in a 2010 revision of the US Department of Energy's list for most valuable chemicals due to its versatility in forming a wide range of useful chemicals. In particular, one of its products, 2,5-furandicarboxylic acid (FDCA), has been widely acknowledged for its potential to replace polyethylene terephthalate (PET) in plastic production with comparable mechanical strength and superior cost savings [63-65]. The recent advances in anodic electroreforming of 5-HMF will be discussed in this section.

In 5-HMF oxidation, either the alcohol group or aldehyde group can be oxidized first, forming the intermediates 2,5-diformylfuran (DFF) or 5-hydroxymethyl-2-furancarboxylic acid (HMFCA), respectively (Figure 10). Next, the intermediates further undergo oxidization into 5-formyl-2-furancarboxylic acid (FFCA) and lastly into FDCA.

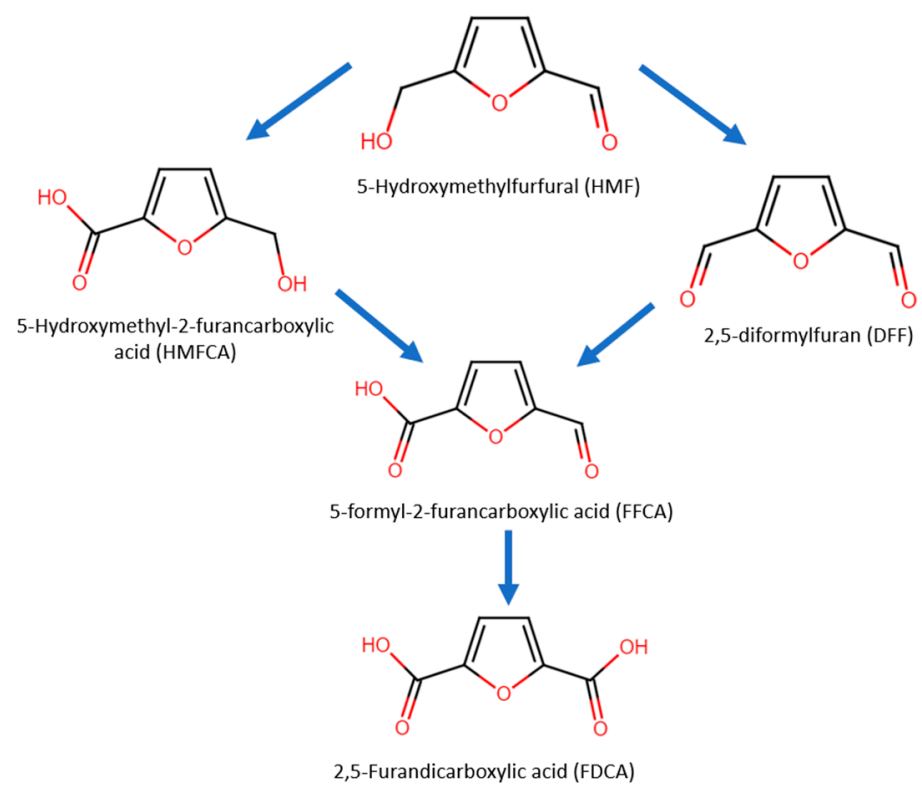

Figure 10. Oxidation pathways and products of 5-HMF.

In 2018, Liu et al. fabricated NiFe layered double hydroxide (LDH) nanosheets on carbon paper as electrocatalysts to electroreform 5-HMF to 2,5-furandicarboxylic acid (FDCA) [66]. Upon adding $10 \mathrm{mM} 5-\mathrm{HMF}$, LSV scans revealed onset potential at $1.25 \mathrm{~V}$ (vs. RHE) occurred earlier than the oxygen evolution reaction (OER) at $1.37 \mathrm{~V}$ for double layer capacitance, which further supported the suggestion that there is a greater electrochemically active area for 5-HMF oxidation than that for oxygen evolution. Among the LDH materials, including bimetallic nickel-aluminum (NiAl), nickel-gallium $(\mathrm{NiGa})$, and $\mathrm{Ni}(\mathrm{OH})_{2}, \mathrm{NiFe}$ displayed the best performance. Additional chronoamperometric tests at a potential of $1.33 \mathrm{~V}$ resulted in the best 5-HMF conversion of $98 \%$ and an FDCA yield of $98 \%$, with Faradaic efficiency of $98.6 \%$ in $1 \mathrm{M}$ potassium hydroxide electrolyte with $10 \mathrm{mM} 5$-HMF. When the concentration of 5-HMF was increased to $100 \mathrm{mM}$, good conversion, yield, as well as efficiency were still observed (all values $>90 \%$ ).

Weidner et al. investigated the electrooxidation of 5-HMF to FDCA with bimetallic cobalt-metalloid alloys to replace OER in water splitting [67]. Among cobalt phosphide $(\mathrm{CoP})$, cobalt boride $(\mathrm{CoB})$, cobalt telluride $(\mathrm{CoTe})$, dicobalt silicide $\left(\mathrm{CO}_{2} \mathrm{Si}\right)$ and cobalt arsenide (CoAs), $\mathrm{CoB}$ had the highest current activity $\left(2.69 \mathrm{~mA} / \mathrm{cm}^{2}\right.$ at $\left.1.45 \mathrm{~V}\right)$, where OER is negligible, and the lowest onset potential for $1 \mathrm{~mA} / \mathrm{cm}^{2}$ was $1.39 \mathrm{~V}$, as displayed in Figure 11a,b. 

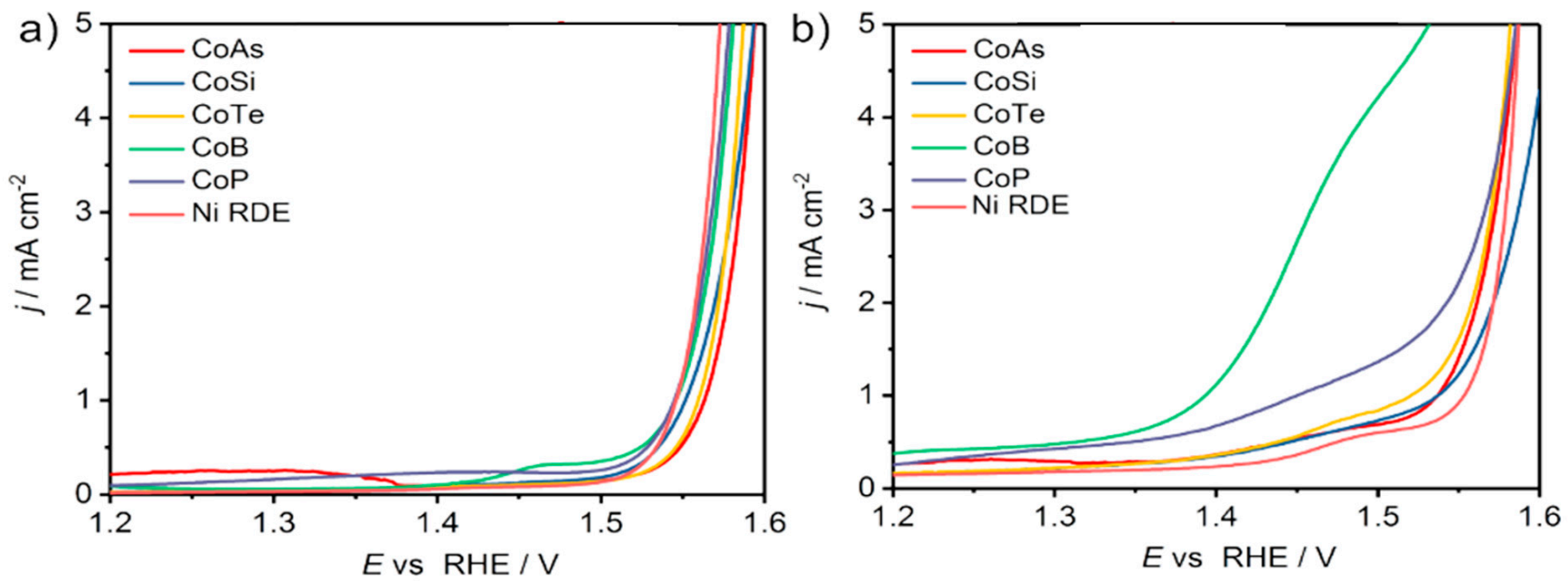

Figure 11. LSV scans of cobalt alloys in half cell in $1 \mathrm{M} \mathrm{KOH}$, (a) without the addition of 5-HMF (OER), and (b) with the addition of $10 \mathrm{mM}$ 5-HMF (5-HMF oxidation to FDCA). Reprinted with permission from Ref. [67]. Copyright 2018, Beilstein Journal of Organic Chemistry.

A flow reactor was then constructed with CoB-doped $\mathrm{Ni}$ foam as a positive electrode and $\mathrm{Ni}$ foam as a negative electrode, separated by anion exchange membrane. Figure $12 \mathrm{a}, \mathrm{b}$ show the smooth surface of the Ni foam, whereas Figure $12 \mathrm{c}, \mathrm{d}$ reveal the rough appearance of the CoB-doped foam due to agglomerations of CoB after spray coating deposition. As illustrated in Figure 12e, the current density at anodic potential of $1.45 \mathrm{~V}$ was $55 \mathrm{~mA} / \mathrm{cm}^{2}$ with additional $10 \mathrm{mM}$ 5-HMF. Furthermore, by maintaining potential at $1.45 \mathrm{~V}$, complete conversion of 5-HMF was realized. The FDCA yield attained was $94 \%$ and Faradaic efficiency was 98\%, as seen in Figure 12f. Notably, the degradation of 5-HMF into humintype structures, typically observed at high $\mathrm{pH}$, was suppressed. Remarkably, the current density at the applied voltage $(1.45 \mathrm{~V})$ recorded at $55 \mathrm{~mA} / \mathrm{cm}^{2}$, much lower than the $1.63 \mathrm{~V}$ required for the same current density at OER.
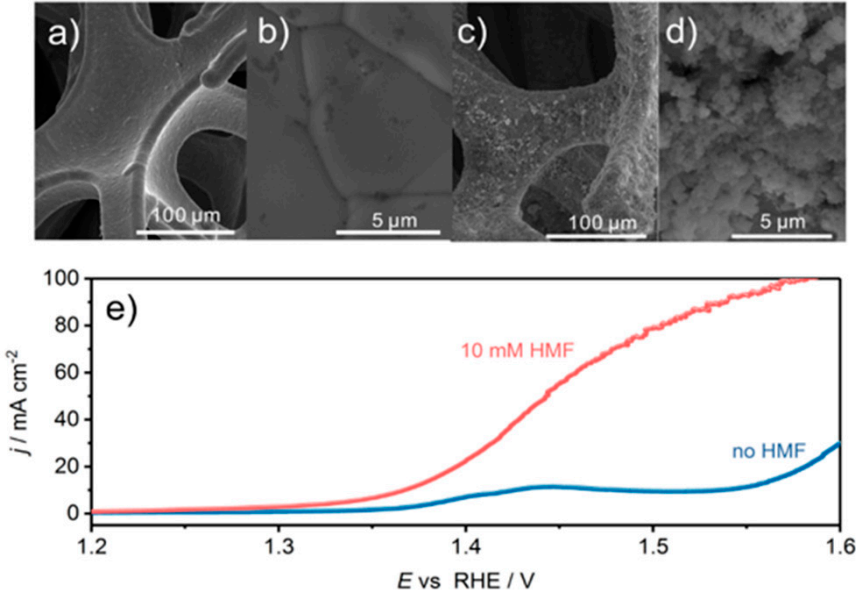

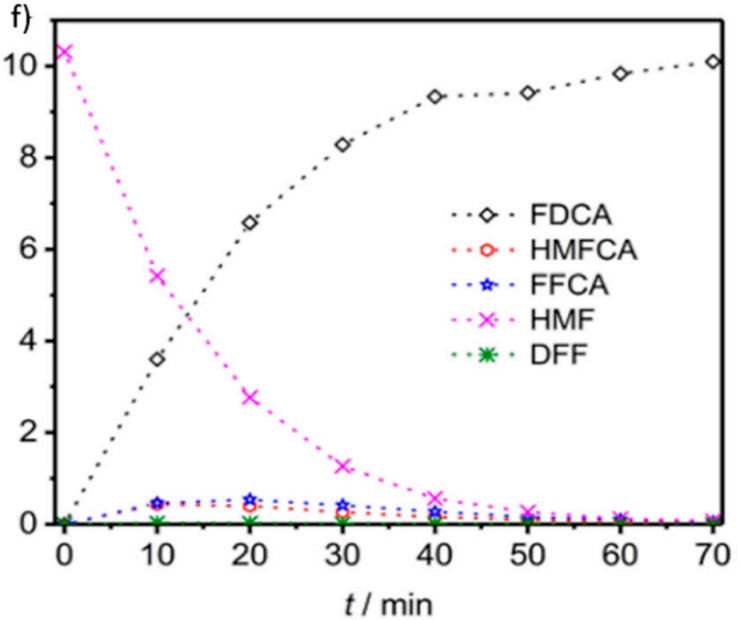

Figure 12. (a,b) SEM images of nickel foam before CoB deposition. (c,d) SEM of foam after CoB deposition. (e) LSV in flow reactor with and without 5-HMF. (f) Concentration against time for various products. Reprinted with permission from Ref. [67]. Copyright 2018, Beilstein Journal of Organic Chemistry.

Suspecting that highly alkali conditions favor the degradation of 5-HMF into insoluble humin products, Nam et al. used an electrolyte with a $\mathrm{pH}$ of $13(0.1 \mathrm{M} \mathrm{KOH})$, rather than a $\mathrm{pH}$ of 14, for electroreforming 5-HMF to FDCA [68]. Nanocrystalline $\mathrm{Cu}$ foam was used as the electrocatalyst due to $\mathrm{Cu}$ 's high overpotential requirement for the competing reaction (i.e., oxygen evolution). LSV scans of 5-HMF and intermediates confirmed that complete 
conversion 5-HMF to FDCA can be accomplished without oxygen evolution, as shown in Figure 13a. Anodic potential of $1.62 \mathrm{~V}$ with $0.1 \mathrm{mM}$ 5-HMF at $\mathrm{pH}$ of 13 led to $99.9 \%$ of 5 -HMF conversion, $96.4 \%$ of FDCA yield, and $95.3 \%$ of Faradaic efficiency. The authors also tested bulk $\mathrm{Cu}$ electrode, while maintaining high conversion (99.1\%), achieving lower FDCA yield (80.8\%) and Faradaic efficiency $(79.9 \%)$. Although LSV scans indicated lower activity for bulk $\mathrm{Cu}$, with a potential (at $1 \mathrm{~mA} / \mathrm{cm}^{2}$ ) of $1.58 \mathrm{~V}$ compared to $1.45 \mathrm{~V}$ for nanoparticle $\mathrm{Cu}$, it was still significantly lower than the $1.8 \mathrm{~V}$ required for OER. From the product analysis, substantial amounts of FFCA were found, suggesting that oxidation of FFCA to FDCA was the rate limiting step.

In 2019, Taitt et al. went on to compare performances of various transition metal oxyhydroxides such as $\mathrm{NiOOH}, \mathrm{CoOOH}$ and $\mathrm{FeOOH}$ for the oxidation of 5- $\mathrm{HMF}$ into FDCA [69]. 5-HMF oxidation was induced at the lowest potential using $\mathrm{CoOOH}$. However, the authors reported that the current density obtained was too low for practical use, and increasing potentials further resulted in OER. On the other hand, $\mathrm{FeOOH}$ exhibited no catalytic activity at potentials below OER. Among those tested in $0.1 \mathrm{M} \mathrm{KOH}$ with $5 \mathrm{mM}$ $5-\mathrm{HMF}, \mathrm{NiOOH}$ appeared to be the best catalyst, attaining $99.8 \%$ conversion, $96 \%$ yield and $96 \%$ Faradaic efficiency at $1.47 \mathrm{~V}$ (Figure 13b). These similar results were also obtained previously by Liu's and coworkers [66].

Kang et al. then investigated the activities of Co-based oxides as electrocatalysts [70]. Specifically, nickel cobaltite $\left(\mathrm{NiCO}_{2} \mathrm{O}_{4}\right)$ and cobalt (II, III) oxide $\left(\mathrm{Co}_{3} \mathrm{O}_{4}\right)$ were deposited onto $\mathrm{Ni}$ foam. It can be observed from Figure $13 \mathrm{c}$ that the OER onset potentials for $\mathrm{NiCo}_{2} \mathrm{O}_{4}$ and $\mathrm{Co}_{3} \mathrm{O}_{4}$ with $1 \mathrm{M} \mathrm{KOH}$ were 1.47 and $1.42 \mathrm{~V}$, respectively. However, both dropped to $\sim 1.2 \mathrm{~V}$ after adding 5-HMF. $\mathrm{NiCo}_{2} \mathrm{O}_{4}$ 's lower Tafel slope indicated the ease of promoting activity, which was confirmed through LSV scans using intermediates (HMFCA and FFCA). At the anodic potential of $1.5 \mathrm{~V}$ with $1 \mathrm{M} \mathrm{KOH}$ with $5 \mathrm{mM} 5-\mathrm{HMF}$, the conversion and selectivity of 5-HMF to FDCA were $99.6 \%$ and $90.8 \%$, respectively. It is noted that a higher portion of $\mathrm{Co}^{3+}$ was reduced to $\mathrm{Co}^{2+}$ in $\mathrm{NiCo}_{2} \mathrm{O}_{4}$, which accounted for its more superior performance.

In 2020, Cai et al. investigated HMF oxidation to FDCA using nickel (II)-modified covalent-organic framework (COF) film TpBpy-Ni@FTO [71]. However, LSV scan with $0.1 \mathrm{M} \mathrm{LiClO}_{4}$ (pH of 13) and $0.5 \mathrm{M} 5-\mathrm{HMF}$ revealed that the potential was about $1.7 \mathrm{~V}$ for $0.1 \mathrm{~mA} / \mathrm{cm}^{2}$. Moreover, the maximum yields were relatively low; with an anodic potential of $1.55 \mathrm{~V}, 0.5 \mathrm{mM} 5-\mathrm{HMF}$ resulted in $96 \%$ conversion, a $34 \%$ yield of intermediate FFCA, and a $58 \%$ yield of FDCA.

Huang et al. introduced oxygen vacancies by doping $\mathrm{CoO}$ with selenium (Se) to form $\mathrm{CoO}-\mathrm{CoSe}_{2}$ electrocatalyst with Co:Se molar ratio of 23:1 [72]. The catalysts were dispersed onto carbon paper support, and electrochemical activities investigated through LSV in $1 \mathrm{M} \mathrm{KOH}$, with and without $10 \mathrm{mM}$ 5-HMF. It can be observed from Figure 13d that the onset potential without 5-HMF was reported to be $1.5 \mathrm{~V}$ and with $10 \mathrm{mM} 5-\mathrm{HMF}$ was $1.3 \mathrm{~V}$. Overall, $\mathrm{CoO}-\mathrm{CoSe}_{2}$ showed better performance than $\mathrm{CoO}$ and $\mathrm{CoSe}_{2}$. In a three-electrode cell, anodic potential of $1.43 \mathrm{~V}$ fully converted 5-HMF to FDCA with a yield of $99 \%$ and Faradaic efficiency of $97.9 \%$. After five cycles, no decrease in yields and conversions were observed. Likewise, a similar setup with a carbon paper-only electrode (without $\mathrm{CoO}-\mathrm{CoSe}_{2}$ ) was performed as a reference and showed significantly lower 5-HMF conversion of $58.3 \%$, with trace FDCA $(0.5 \%)$ and significant humin-type products.

In 2021, Hu et al. prepared tungsten trioxide $\left(\mathrm{WO}_{3}\right)$ on $\mathrm{Ni}$ foam at relatively low temperatures $\left(180^{\circ} \mathrm{C}\right)$ using varying amounts of polyethylene glycol (PEG) additive [73]. Without 5-HMF, onset potential and potential at $20 \mathrm{~mA} / \mathrm{cm}^{2}$ were 1.32 and $1.6 \mathrm{~V}$, respectively, while the addition of 5-HMF reduced them to 1.18 and $1.44 \mathrm{~V}$, respectively. Conducting CVs at varying scan rates revealed that $\mathrm{WO}_{3} / \mathrm{Ni}_{0.18}\left(0.18 \mathrm{~g}\right.$ of $\mathrm{PEG}$ per $\mathrm{cm}^{2}$ of electrode) had the largest electrochemically active surface area. In a 3-electrode electrochemical cell with $1 \mathrm{M}$ potassium hydroxide and $5 \mathrm{mM} 5-\mathrm{HMF}$ at anodic $1.57 \mathrm{~V}, \mathrm{WO}_{3} / \mathrm{Ni}_{0.18}$ resulted in conversion of $88.6 \%$, an FDCA yield of $81.5 \%$ and a Faradaic efficiency of $79.5 \%$. 
(a)

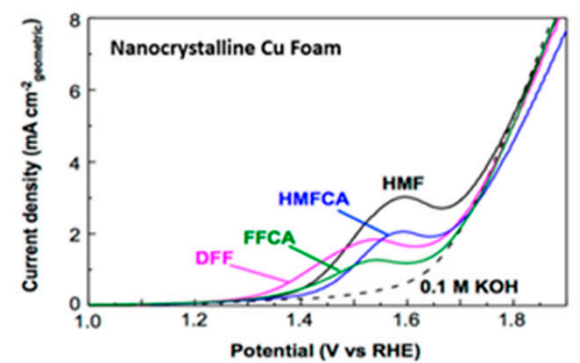

(d)

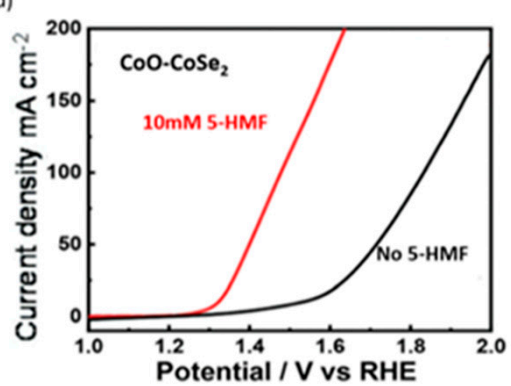

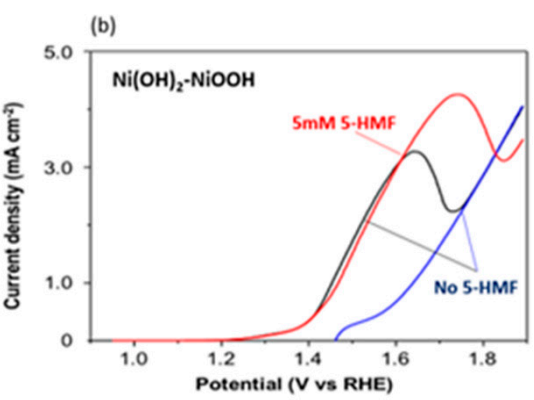
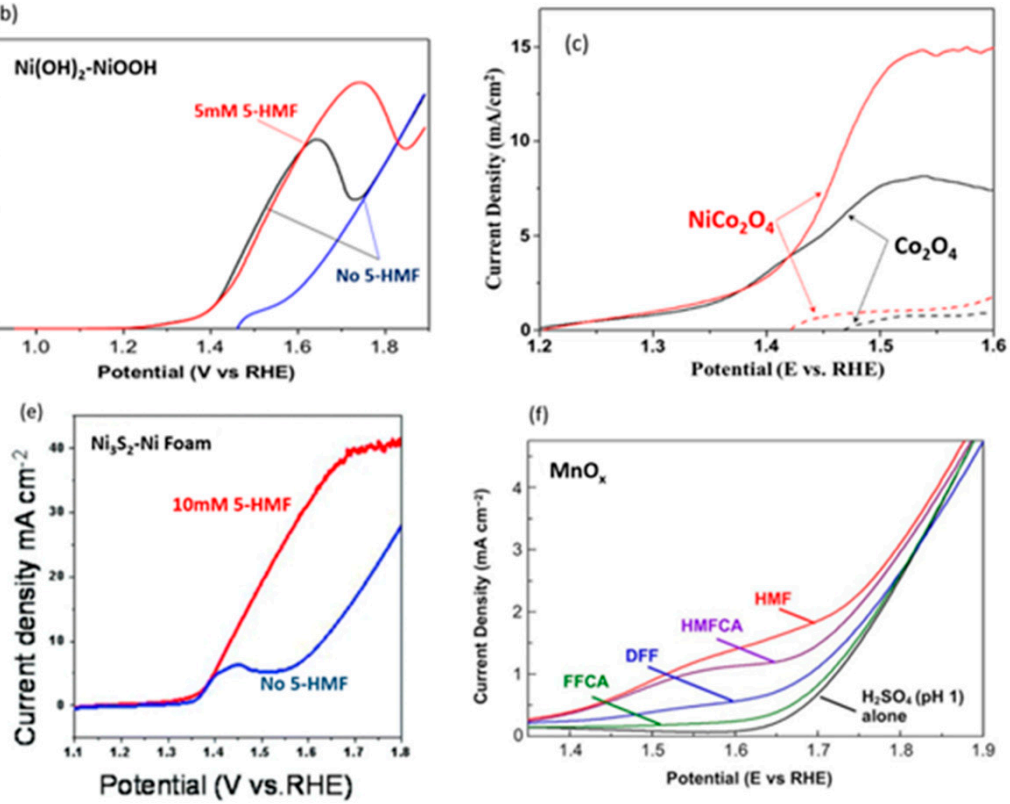

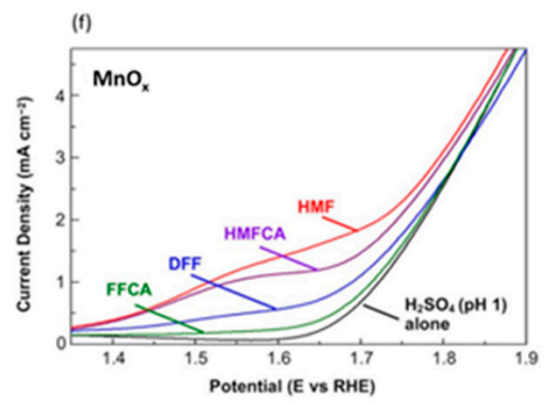

Figure 13. Comparison of LSV graphs with different catalysts. (a) LSV scans of $5 \mathrm{mM}$ of 5-HMF and intermediates (solid lines) and without 5-HMF (dashed line) at a $\mathrm{pH}$ of 13 using nanocrystalline $\mathrm{Cu}$ foam. Reprinted with permission from Ref. [68]. Copyright 2018, ACS Catalysis. (b) LSV of $\mathrm{Ni}(\mathrm{OH})_{2}$ catalysts without (blue and black lines) and with $5 \mathrm{mM}$ 5-HMF (red line) at a pH of 13. Reprinted with permission from Ref. [69]. Copyright 2019, ACS Catalysis. (c) LSV of $\mathrm{NiCo}_{2} \mathrm{O}_{4}$ and $\mathrm{Co}_{3} \mathrm{O}_{4}$ catalysts without (dashed lines) and with (solid lines) $5 \mathrm{mM}$ 5-HMF, at a pH of 13. Reprinted with permission from Ref. [70]. Copyright 2019, Applied Catalysis B: Environmental. (d) LSV of CoO-CoSe 2 electrocatalysts without (black line) and with (red line) $10 \mathrm{mM}$ 5-HMF at a pH of 13. Reprinted with permission from Ref. [72]. Copyright 2020, Green Chemistry. (e) LSV of $\mathrm{Ni}_{3} \mathrm{~S}_{2}$-Nickel foam without (black line) and with (red line) $10 \mathrm{mM}$ 5-HMF at a pH of 13. Reprinted with permission from Ref. [74]. Copyright 2021, Dalton Transactions. (f) LSV of 20 mM 5-HMF and intermediates (colored lines) and without (black line) with $\mathrm{MnO}_{\mathrm{x}}$ at a $\mathrm{pH}$ of 1. Reprinted with permission from Ref. [75]. Copyright 2018, ChemSusChem.

Wang et al. performed sulfidation of $\mathrm{Ni}$ foam at $120^{\circ} \mathrm{C}$ under hydrothermal conditions to produce nickel subsulfide $\left(\mathrm{Ni}_{3} \mathrm{~S}_{2}\right)$ on $\mathrm{Ni}$ foam [74]. Further investigations revealed the presence of $\mathrm{Ni}^{2+}$ and $\mathrm{Ni}^{0}$ species. In $1 \mathrm{M} \mathrm{KOH}$, water oxidation occurred at $1.63 \mathrm{~V}$ with $10 \mathrm{~mA} / \mathrm{cm}^{2}$. Upon the addition of $10 \mathrm{mM} 5-\mathrm{HMF}$, the required potential fell to $1.43 \mathrm{~V}$, as displayed in Figure 13e. In a three-electrode configuration with a graphite counter electrode, maintained at $1.498 \mathrm{~V}$, conversion of $100 \%$, an FDCA yield of $98.3 \%$ and Faradaic efficiency of $93.5 \%$ were obtained. A control experiment with only $\mathrm{Ni}$ foam was conducted to reveal low yield of FDCA (52\%), which supports the enhanced electrocatalytic properties of $\mathrm{Ni}_{3} \mathrm{~S}_{2}$.

In contrast to conventional alkali media, Kubota and Choi investigated the oxidation of 5-HMF to FDCA at a $\mathrm{pH}$ of 1 [75]. The authors aimed to induce FDCA precipitation at low $\mathrm{pH}(<2-3)$, allowing for easier extraction. Using a manganese oxide $\left(\mathrm{MnO}_{\mathrm{x}}\right)$ anode, LSVs were performed in $0.05 \mathrm{M}$ sulfuric acid $\left(\mathrm{H}_{2} \mathrm{SO}_{4}\right)$, with and without $20 \mathrm{mM} 5-\mathrm{HMF}$ and intermediates, as shown in Figure 13f. This confirmed the oxidation of 5-HMF oxidation was favored over OER. Notably, $1.49 \mathrm{~V}$ was needed for $1 \mathrm{~mA} / \mathrm{cm}^{2}$ for $5-\mathrm{HMF}$ oxidation. As a control, $\mathrm{Pt}$ was scanned under the same conditions, and was found to exhibit insignificant electrolytic activity. In a three-electrode cell setup, the anodic potential of $1.6 \mathrm{~V}$ and temperature of $60{ }^{\circ} \mathrm{C}$ were maintained. Elevated temperatures improved the kinetics and solubility of FDCA, which limited precipitation of FDCA on anode. After the reaction, the temperature was lowered to precipitate FDCA, as well as intermediate 5-formyl-2furancarboxylic acid (FFCA). Almost all 5-HMF were converted (up to 99.9\%), while it yielded $53.8 \%$ of FDCA and the Faradaic efficiency was 33.8\%. Apart from FDCA intermediates, maleic acid was also measured with a yield of $21.9 \%$. 


\subsection{Other Biomass Derivatives}

Minor research efforts have been devoted to other cellulose-derived biomass such as levulinic acid $\left(\mathrm{C}_{5} \mathrm{H}_{8} \mathrm{O}_{3}\right)$. In 2015, Dos Santos et al. performed the oxidation of levulinic acid to 2,7-octanedione with $\mathrm{Pt}$ anode in aqueous solution or methanol at $\mathrm{pH}$ of 5.5 [76]. Methanol resulted in much a higher Faradaic efficiency ( $86 \%$ vs. $5 \%$ ) and higher selectivity ( $47 \%$ vs. $27 \%$ ) than water-based electrolytes, while using water allowed for slightly higher conversions ( $74 \%$ vs. $60 \%$ ). 4-hydroxy-2-butanone was also produced directly, using $\mathrm{Pt}$ at $6 \mathrm{~V}$ in $0.2 \mathrm{M} \mathrm{NaOH}$, resulting in $6 \%$ selectivity and 5\% Faradaic efficiency. The major oxidation product ( $\sim 5 \%$ selectivity) was identified as 3-buten-2-one. Further electrochemical hydrogenation and oxidation of products were also investigated. For instance,1,3-butanediol and 1-butanol were obtained from 4-hydroxy-2-butanone, and octane from valeric acid, as mentioned in [77]. Cathodic electroreforming of levulinic acid will be further discussed in later sections.

Glycerol $\left(\mathrm{C}_{3} \mathrm{H}_{8} \mathrm{O}_{3}\right)$ is a by-product triol obtained through the production of biofuel [78]. The growing popularity of biofuel synthesis in the last decade has resulted in a larger supply of glycerol, spurring extensive research into glycerol electroreforming, which is summarized in the reviews [79-81]. Most research employs precious metal electrocatalysts for glycerol electroreforming to valuable chemicals. However, in 2019, Liu et al. successfully used $\mathrm{CuO}$ to synthesize 1,3-dihydroxyacetone (DHA), a commercially valuable chemical with applications in cosmetics and polymer industries [82,83]. At the applied current density $\left(3 \mathrm{~mA} / \mathrm{cm}^{2}\right)$ and $\mathrm{pH}$ level 9 , a selectivity of $60 \%$ to DHA was achieved.

In 2021, Vo et al. utilized $\mathrm{CoO}_{\mathrm{x}}$ catalysts for anodic glycerol valorization at a $\mathrm{pH}$ of 9 [84]. Operando characterization was performed to track the surface species of electrocatalysts, and oxidation pathways were proposed, as shown in Figure $14 . \mathrm{CoO}_{\mathrm{x}}$ was first electrochemically oxidized into oxyhydroxides to form active sites. Then, glycerol underwent indirect electron transfer to be incompletely oxidized to DHA or glyceraldehyde, or completely oxidized to formic acid. Spectroscopy results indicated that incomplete oxidation was more likely to occur, although formic acid was present at all applied potentials. At an applied potential of $1.5 \mathrm{~V}$, a DHA selectivity of $60 \%$ was attained.
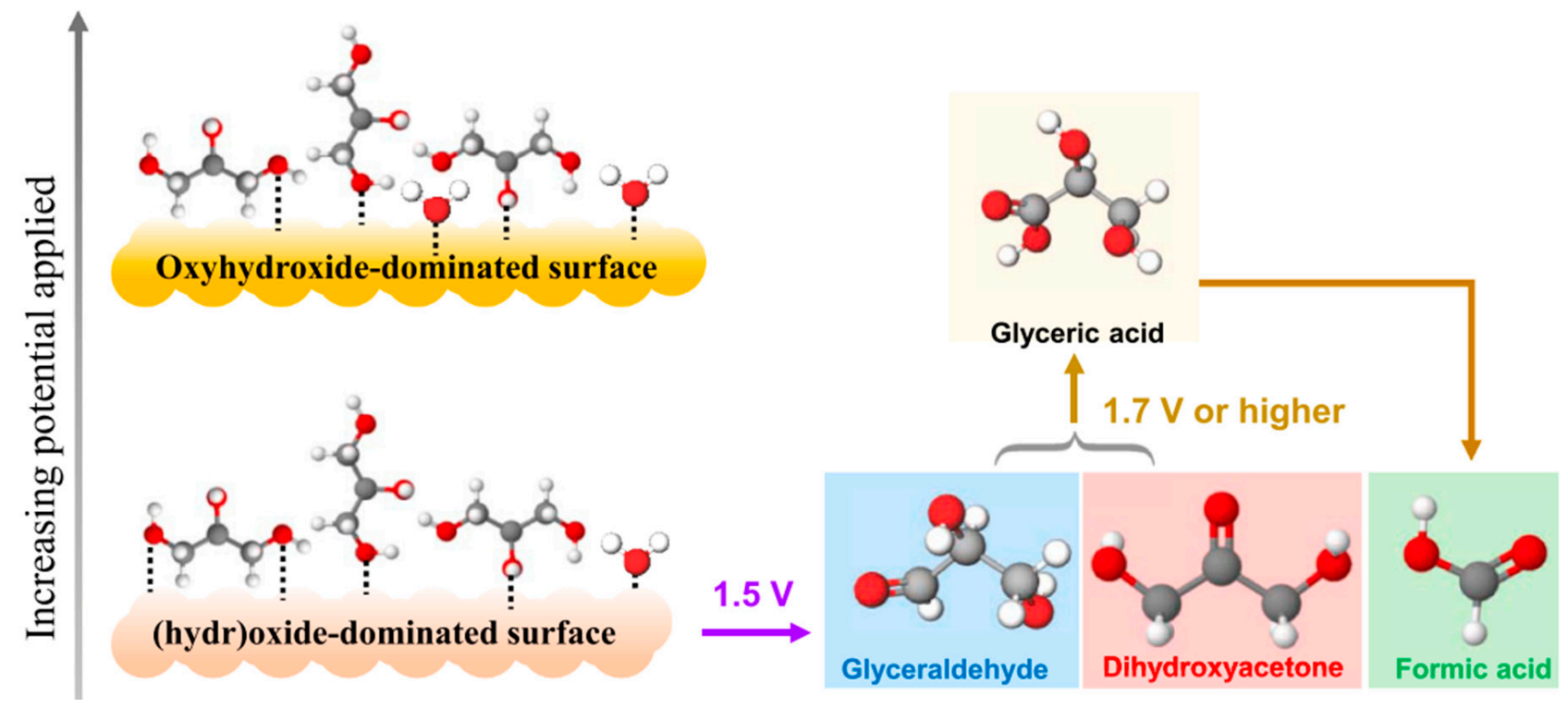

Figure 14. Proposed glycerol oxidation pathway over $\mathrm{CoO}_{x}$ in mild alkali media. Reprinted with permission from Ref. [84]. Copyright 2021, Applied Catalysis B: Environmental. 
Sorbitol $\left(\mathrm{C}_{6} \mathrm{H}_{14} \mathrm{O}_{6}\right)$ is a biomass-derived polyol identified as a promising platform chemical [46]. While most electrochemical studies on sorbitol focused on anodic oxidation in fuel cells, in 2019, Kwon et al. electrochemically oxidized sorbitol to glucose, gulose, fructose and sorbose on a Sb-modified Pt anode in a Bi-saturated $\mathrm{pH} 3$ solution [85]. Although high selectivity to a single product was not obtained, selectivity to value-added products was shown to be influenced by potential. The researchers suggest that more studies might uncover a new pathway to electrochemically convert glucose to fructose through sorbitol.

Furfural $\left(\mathrm{C}_{5} \mathrm{H}_{4} \mathrm{O}_{2}\right)$ is one of the oldest biomass-derived chemicals which can undergo electrochemical hydrogenation to form 5-HMF [86,87]. Recent works have also demonstrated anodic electroreforming of furfural to maleic acid, which is widely used in the synthesis of resins and pharmaceuticals. In 2018, Kubota and Choi used $\mathrm{PbO}_{2}$ electrodes in acidic media with a $\mathrm{pH}$ of 1 and found that the onset current decreased from 1.85 to $1.6 \mathrm{~V}$ upon the addition of $10 \mathrm{mM}$ furfural [88]. Furfural was first oxidized to 2-furanol and finally to maleic acid with a yield of $65.1 \%$. In 2020, Roman et al. also reported anodic reforming of furfural to furoic acid, a chemical to produce 2,5-furandicarboxylic acid [89]. A Faradaic efficiency of $96 \%$ was attained for furoic acid on Au electrodes at $0.8 \mathrm{~V}$ and a $\mathrm{pH}$ of 0.6 , although low current densities $\left(<30 \mu \mathrm{A} / \mathrm{cm}^{2}\right)$ suggest the rate of reaction might be slower than desired. Notably, through density functional theory and attenuated total reflectance surface-enhanced infrared absorption spectroscopy (ATR-SEIRAS) studies, the desorption of furoate from electrode surface was suggested as the rate-limiting step at $\mathrm{Au}$ and Pt electrodes. This hypothesis was validated using further $\mathrm{CV}$ characterizations of furfural oxidation in the presence and absence of furoic acid. Small quantities (1\%) of furoic acid were sufficient to inhibit furfural oxidation in acidic conditions.

Studies on electroreforming of cellulose and its derivatives as well as other biomass derivatives at the anode are summarized in Table 1 with the key technical information. 
Table 1. Studies investigating electroreforming of biomass at the anode.

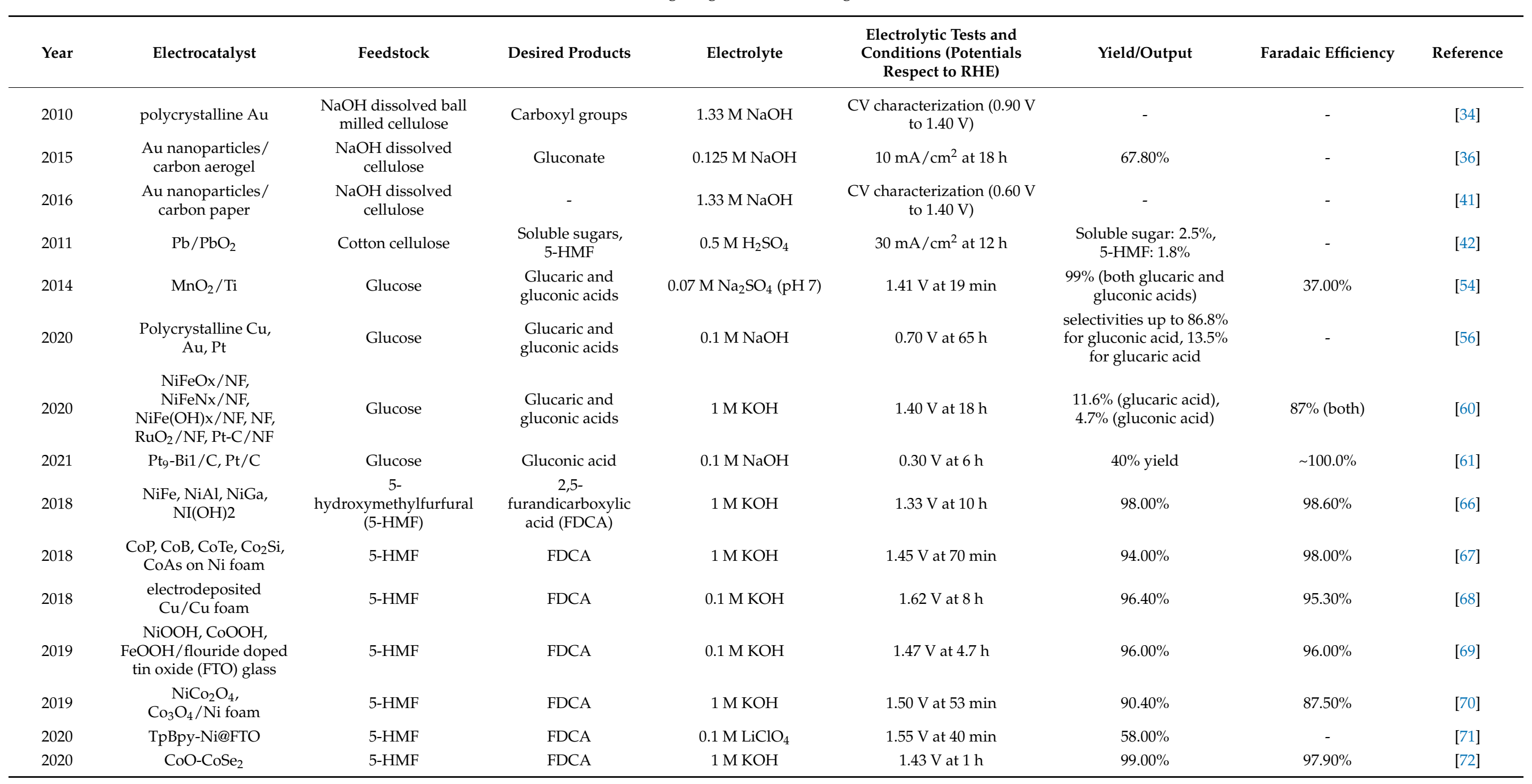


Table 1. Cont.

\begin{tabular}{|c|c|c|c|c|c|c|c|c|}
\hline Year & Electrocatalyst & Feedstock & Desired Products & Electrolyte & $\begin{array}{l}\text { Electrolytic Tests and } \\
\text { Conditions (Potentials } \\
\text { Respect to RHE) }\end{array}$ & Yield/Output & Faradaic Efficiency & Reference \\
\hline 2021 & WO3 on Ni foam & 5-HMF & FDCA & $1 \mathrm{M} \mathrm{KOH}$ & $1.57 \mathrm{~V}$ at $351 \mathrm{~min}$ & $81.50 \%$ & $79.50 \%$ & [73] \\
\hline 2018 & MnOx/FTO glass & 5-HMF & $\begin{array}{l}\text { FDCA and maleic } \\
\text { acid }\end{array}$ & $0.05 \mathrm{H}_{2} \mathrm{SO}_{4}$ & $\begin{array}{l}1.60 \mathrm{~V} \text { (duration not } \\
\text { reported) }\end{array}$ & $\begin{array}{l}53.8 \% \text { FDCA, } 21.9 \% \\
\text { maleic acid }\end{array}$ & $33.8 \%$ (FDCA) & [75] \\
\hline 2015 & $\mathrm{Pt}, \mathrm{C}, \mathrm{Cu}, \mathrm{Fe}, \mathrm{Ni}, \mathrm{Pb}$ & Levulinic acid & $\begin{array}{c}\text { Valeric acid, } \\
\text { g-valerolactone, 4- } \\
\text { hydroxy-2-butanone } \\
\text { and other } \\
\text { hydrocarbons }\end{array}$ & $\begin{array}{c}0.5 \mathrm{M} \mathrm{H}_{2} \mathrm{SO}_{4}(\mathrm{C} \text { for } \\
\text { g-valerolactone and } \mathrm{Pb} \\
\text { for valeric acid), } 0.2 \mathrm{M} \\
\mathrm{NaOH} \text { (C for 4- } \\
\text { hydroxy-2-butanone) }\end{array}$ & $\begin{array}{c}-1.80 \mathrm{~V} \text { (g-valerolactone } \\
\text { and valeric acid), } 6.00 \mathrm{~V} \\
\text { (4-hydroxy-2-butanone), at } \\
4 \text { to } 8 \mathrm{~h}\end{array}$ & $\begin{array}{c}27.2 \% \text { for } \\
\text { g-valerolactone, } \sim 56 \% \text { for } \\
\text { valeric acid, } 6 \% \\
\text { selectivity for } \\
\text { 4-hydroxy-2-butanone }\end{array}$ & $\begin{array}{c}60.0 \% \text { for valeric } \\
\text { acid, } 18.0 \% \text { for } \\
\text { g-valerolactone, } 5.0 \% \\
\text { for 4-hydroxy-2- } \\
\text { butanone }\end{array}$ & [76] \\
\hline 2020 & $\mathrm{CuO}$ & Glycerol & $\begin{array}{c}1,3- \\
\text { dihydroxyacetone }\end{array}$ & $0.1 \mathrm{M} \mathrm{Na}_{2} \mathrm{~B}_{4} \mathrm{O}_{7}$ & $3 \mathrm{~mA} / \mathrm{cm}^{2}$ at $3 \mathrm{~h}$ & selectivity of $60.0 \%$ & - & [82] \\
\hline 2021 & $\mathrm{CoOx}$ & Glycerol & $\begin{array}{c}1,3- \\
\text { dihydroxyacetone }\end{array}$ & $0.1 \mathrm{M} \mathrm{Na}_{2} \mathrm{~B}_{4} \mathrm{O}_{7}$ & $1.50 \mathrm{~V}$ at $3 \mathrm{~h}$ & selectivity of $60.0 \%$ & $49.40 \%$ & [84] \\
\hline 2015 & $\mathrm{Bi}-\mathrm{Pt} / \mathrm{C}, \mathrm{Sb}-\mathrm{Pt} / \mathrm{C}$ & Sorbitol & Varied & $0.5 \mathrm{M} \mathrm{H}_{2} \mathrm{SO}_{4}$ & $\begin{array}{c}\mathrm{CV} \text { characterization }(0 \text { to } \\
1.60 \mathrm{~V})\end{array}$ & - & - & [85] \\
\hline 2018 & $\mathrm{PbO}_{2}, \mathrm{MnO}_{2}, \mathrm{Pt}$ & Furfural & Maleic acid & $\mathrm{H}_{2} \mathrm{SO}_{4}(\mathrm{pH}$ of 1$)$ & $\begin{array}{l}2.00 \mathrm{~V} \text { (duration } \\
\text { not reported) }\end{array}$ & $65.10 \%$ & - & [88] \\
\hline 2020 & $\mathrm{Au} /$ Carbon cloth & Furfural & Furoic acid & $0.25 \mathrm{M} \mathrm{HClO}_{4}$ & $\begin{array}{c}\mathrm{CV} \text { characterization }(0 \text { to } \\
1.50 \mathrm{~V})\end{array}$ & - & - & [89] \\
\hline
\end{tabular}




\section{Electroreforming of Biomass at the Cathode}

In addition to oxidation at the anode, hydrogenation or reduction can also be conducted at the cathode of electrolytic cells. In hydrogenation, $\mathrm{H}^{+}$ions in the solution are reduced to surface-bound atomic hydrogen. Oxygenated organic molecules can react with adsorbed hydrogen to form valuable products. This section details some case studies of electroreforming biomass-derived compounds via cathodic reactions.

\subsection{Cellulose}

In 2014, Yang et al. investigated the electroreduction of cellulose oligosaccharides into glucose in acidic media [90]. Short chain oligosaccharides were first produced via hydrothermal treatment with an acidic catalyst. The authors varied the $\mathrm{pH}$, applied voltage, electrolysis duration, and electrode preparation to optimize glucose yield. With a $5 \% \mathrm{MnO}_{2} /$ graphite/polytetrafluoroethylene (PTFE) cathode calcinated at $500{ }^{\circ} \mathrm{C}$ for $3 \mathrm{~h}$, a glucose yield of $72.4 \%$ with $100 \%$ selectivity was reported under optimal electrolysis conditions ( $\mathrm{pH}$ of 3, 8-h reaction duration, and potential of $-0.58 \mathrm{~V}$ vs. RHE). Figure $15 \mathrm{a}, \mathrm{b}$ depicted the product analysis by HPLC before and after electroreforming.

(a)

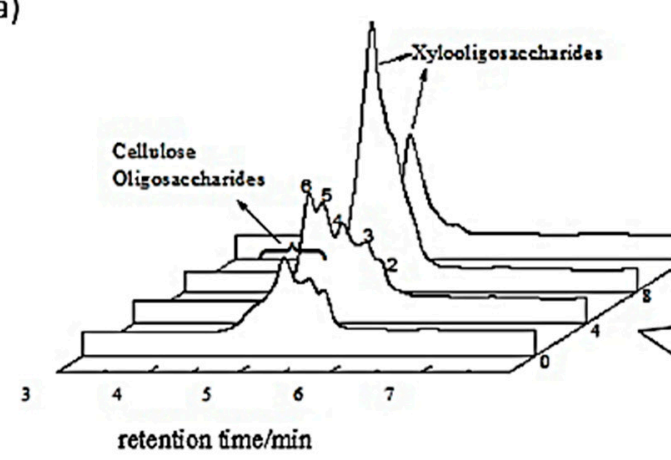

(b)

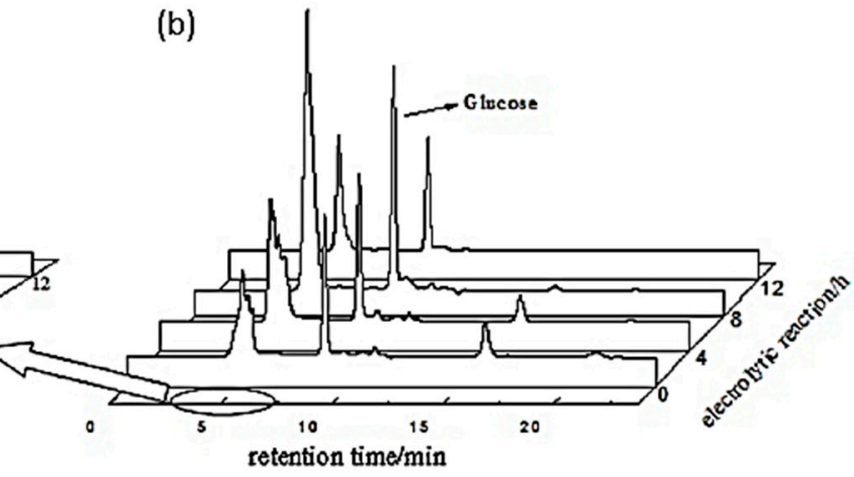

(c)
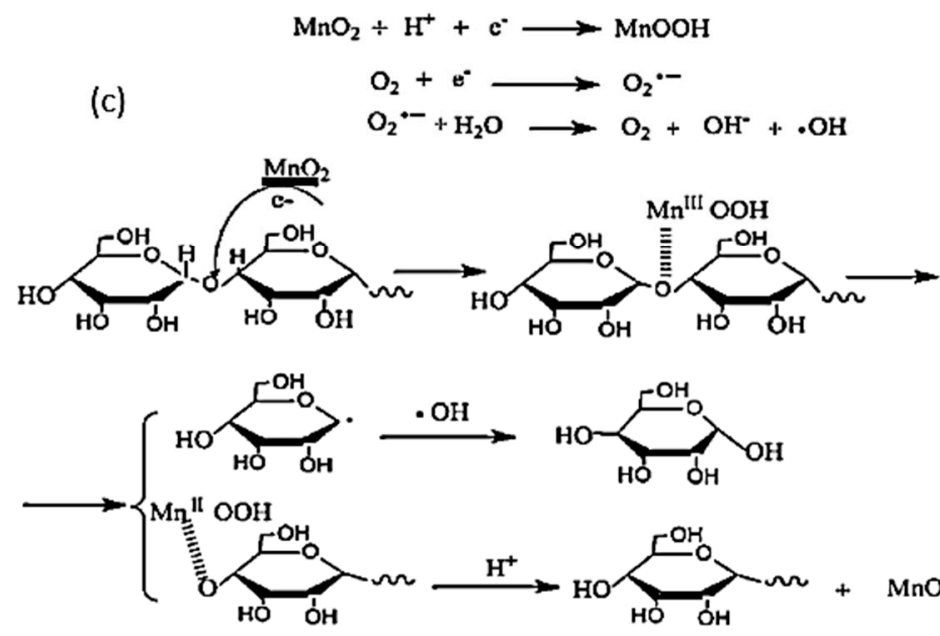

$\mathrm{MnO}_{2}$

Figure 15. (a) HPLC of oligosaccharides after electrolysis. (b) HPLC of products after hydrothermal treatment of cellulose. (c) Proposed mechanism for cellulose oligosaccharide depolymerization with $\mathrm{MnO}_{2}$ cathode. Reprinted with permission from Ref. [90]. Copyright 2014, Journal of Industrial and Engineering Chemistry.

Similar to the electrooxidation mechanism with a gold electrode proposed by Sugano's group [35], Yang et al. hypothesized that cellulose would first adsorb onto the surface of a $\mathrm{MnO}_{2}$ /graphite/PTFE cathode, as shown in Figure 15c. Mn (VI) (in $\mathrm{MnO}_{2}$ ) would be reduced to $\mathrm{Mn}$ (III) (in $\mathrm{MnOOH}$ ) after reaction with a $\mathrm{H}^{+}$ion and electron. Afterwards, $\mathrm{MnOOH}$ coordinates with oxygen in the glycosidic bond, depolymerizing the cellulose chain. Lastly, $\mathrm{MnOOH}$ is re-oxidized into $\mathrm{MnO}_{2}$ in the acidic medium. 


\subsection{5-Hydroxylmethylfurfural}

5-HMF can undergo hydrogenation to form valued products, as shown in Figure 16. Products such as 2,5-dimethylfuran (DMF) are considered potential gasoline alternatives, due to their high carbon and energy density [66,91-93]. 2,5-dihydroxymethylfuran (DHMF) is a platform chemical for polyester and polyurethane foam production [94]. Conventional hydrogenation of 5-HMF often requires high temperatures and/or pressures, as well as hydrogen atmosphere [95]. Electrochemical hydrogenation represents an attractive alternative to produce these chemicals without requiring harsh conditions.

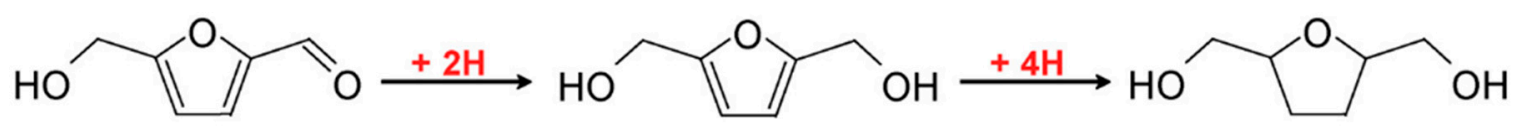

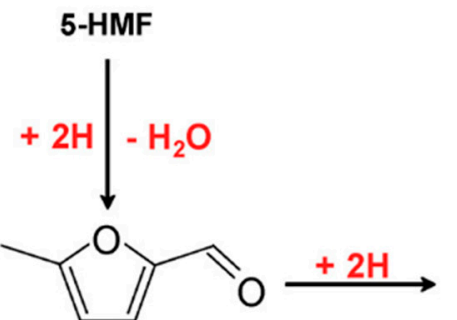

2,5-dihydroxymethylfuran

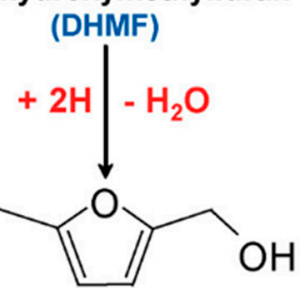

5-methylfurfural (MF)

5-methylfurfuryl alcohol

(MFA)

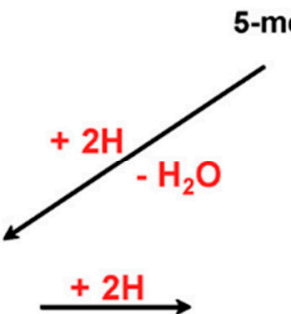

\section{2,5-dihydroxymethyltetrahydrofuran (DHMTHF)}

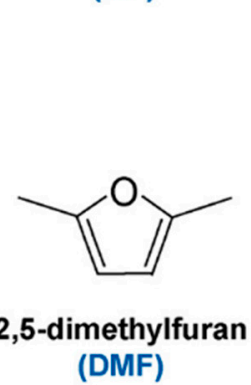

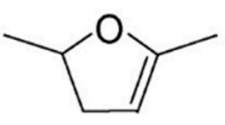

2,5-dimethyl-2,3-dihydrofuran (DMDHF)

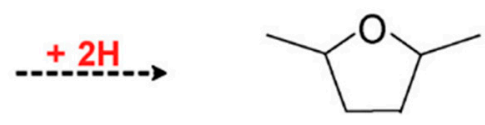
2,5-dimethyltetrahydrofuran
(DMTHF)

Figure 16. Hydrogenation pathways of 5-HMF. Reprinted with permission from Ref. [92]. Copyright 2015, ChemSusChem.

In 2013, Nilges and Schroder first demonstrated electrochemical hydrogenation of 5-HMF to DMF [87]. At a constant $10 \mathrm{~mA} / \mathrm{cm}^{2}$ in a $0.5 \mathrm{M}$ sulfuric acid electrolyte with $\mathrm{Cu}$ electrodes, the highest DMF selectivity of $35.6 \%$ was attained. As reaction proceeded, a significant decrease in Faradaic efficiency was observed alongside a decrease in 5-HMF concentration in the solution. The authors proposed that a flow reactor would allow for sparingly soluble DMF products to be continuously removed, therefore maintaining high Faradaic efficiencies for 5-HMF electroreforming.

Kwon et al. explored electrocatalytic hydrogenation of 5-HMF using different metal catalysts in neutral media ( $0.1 \mathrm{M}$ sodium sulfate buffer, $\mathrm{pH} \sim 7.2)$ in the presence and absence of glucose [91]. Based on the similar onset potentials $(\sim-0.5 \mathrm{~V})$ observed for all metals, they found that the rate of electrocatalytic hydrogenation is not strongly influenced by the catalyst. However, the choice of catalyst was found to influence hydrogenation pathway and products. Broadly, the metal catalysts used were classified into three groups depending on products obtained in neutral media. Firstly, $\mathrm{Fe}, \mathrm{Ni}$, silver $(\mathrm{Ag})$, zinc $(\mathrm{Zn})$, cadmium (Cd), and indium (In) formed DHMF as the major product. Secondly, hydrogenolysis products of 5-HMF were mainly formed on $\mathrm{Co}, \mathrm{Au}, \mathrm{Cu}$, tin ( $\mathrm{Sn}$ ), and antimony (Sb). Finally, using palladium (Pd), $\mathrm{Al}$, bismuth (Bi), and $\mathrm{Pb}$ could form either DHMF or other hydrogenolysis products by controlling the applied potential. Upon the addition of glucose, $\mathrm{Zn}, \mathrm{Cd}, \mathrm{In}, \mathrm{Fe}$, $\mathrm{Ni}, \mathrm{Ag}, \mathrm{Co}$, and Au electrocatalysts favored the hydrogenation of 5-HMF into DHMF, while no such effects of initial glucose concentration on final product preference were observed using $\mathrm{Bi}, \mathrm{Pb}, \mathrm{Sn}$ or $\mathrm{Sb}$. 
Similarly, different metal electrocatalysts were tested in acidic media $\left(0.5 \mathrm{M} \mathrm{H}_{2} \mathrm{SO}_{4}, \mathrm{pH}\right.$ of 0.3) [92], and classified into three groups according to major products. In acidic media, $\mathrm{Fe}, \mathrm{Ni}, \mathrm{Cu}$, and $\mathrm{Pb}$ formed DHMF as the major product. 2,5-dimethyl- 2,3 dihydrofuran (DMDHF) was the major product using $\mathrm{Pd}, \mathrm{Pt}, \mathrm{Al}, \mathrm{Zn}, \mathrm{In}$, and $\mathrm{Sb}$. Using $\mathrm{Co}, \mathrm{Ag}, \mathrm{Au}, \mathrm{Cd}$, $\mathrm{Sb}$, and Bi formed either DHMF or DMDHF as the major product by controlling the applied potential.

In 2019, Chadderdon et al. performed the paired electrocatalytic hydrogenation of 5-HMF at the cathode to produce 2,5-bis(hydroxymethyl)furan (BHMF) [96]. The hydrogenation reaction was catalyzed by $\mathrm{Ag}$ nanoparticles on carbon support in $0.5 \mathrm{M}$ borate buffer solution of $\mathrm{pH}$ 9.2. Electrooxidation of 5-HMF at the anode was performed with homogenous 4-acetamido-TEMPO catalysts. Pairing these anodic and cathodic electroreforming reactions achieved co-generation of valuable products.

5-HMF hydrogenation products were found to be dependent on cathodic potential and 5-HMF concentration, as shown in Figure 17a,b. Increasing the potential or 5-HMF concentration shifted selectivity towards 5,5-bis(hydroxymethyl)hydro-furoin $(\mathrm{BHH})$ rather than BHMF. At the optimum conditions of $-0.46 \mathrm{~V}$ (vs. RHE) and a 5-HMF concentration of $5 \mathrm{mM}, 5-\mathrm{HMF}$ conversion reached $19.7 \%$, while the selectivity and Faradaic efficiency of BHMF production were highest, at $80.9 \%$ and $89.3 \%$, respectively.

(a)

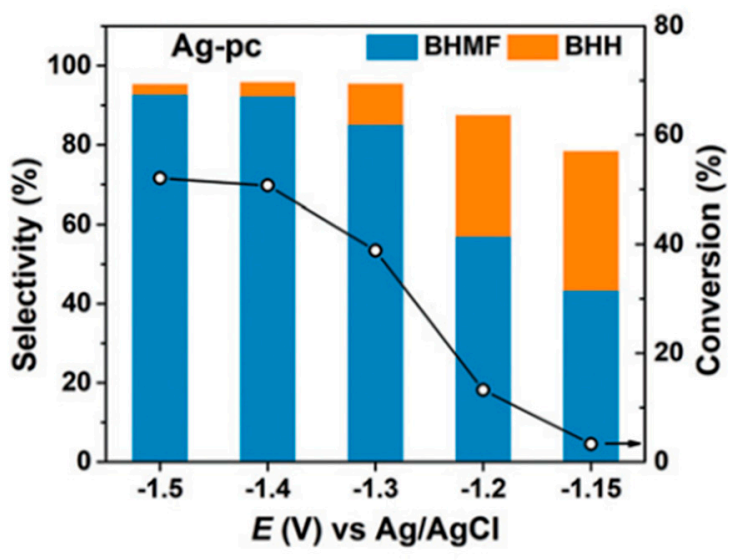

(b)

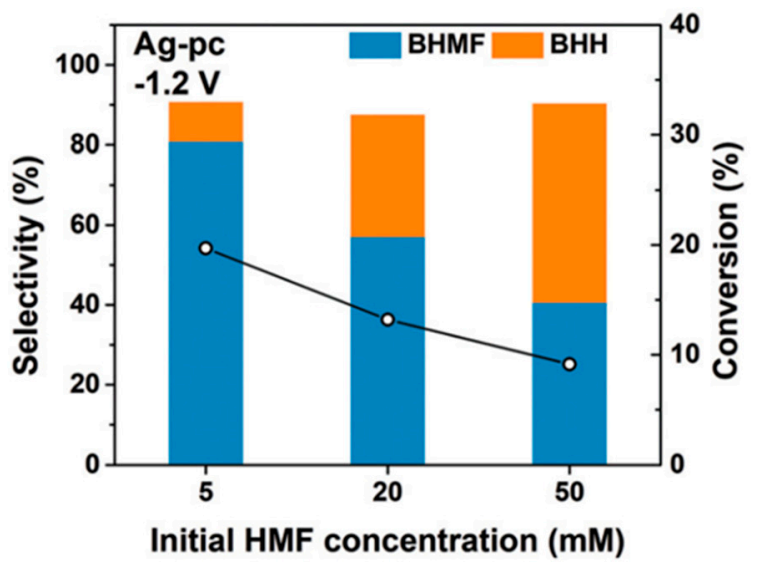

Figure 17. (a) Product selectivities at different cathodic potentials (vs. Ag/AgCl). (b) Product selectivities at different 5-HMF concentrations. Reprinted with permission from Ref. [96]. Copyright 2019, Green Chemistry.

Zhang et al. investigated acidic media for the electrocatalytic hydrogenation of 5-HMF into DMF [97]. Specifically, a bimetallic CuNi electrode (composed of $82 \% \mathrm{Cu}, 17 \% \mathrm{Ni}$ and trace $\mathrm{O}_{2}$ ) was synthesized. After that, LSV scans in $0.2 \mathrm{M}$ sulfate buffer ( $\mathrm{pH}$ of 2 ) were performed. The scans showed a considerable decrease in the magnitude of potential required for $5 \mathrm{~mA} / \mathrm{cm}^{2}$ when $2 \mathrm{~g} / \mathrm{L}(15.9 \mathrm{mM}) 5-\mathrm{HMF}$ was added $(-0.6 \mathrm{~V}$ vs. $-0.36 \mathrm{~V})$, suggesting good electrocatalytic activity for 5-HMF reduction. When the anodic potential of $-0.46 \mathrm{~V}$ (vs. RHE) was maintained for $70 \mathrm{~s}$, a maximum selectivity to DMF of $91.1 \%$ and a Faradaic efficiency of $84.6 \%$ were obtained. Under these conditions, however, the conversion of 5-HMF was low, at $37.8 \%$.

In 2021, Liu et al. conducted electrocatalytic hydrogenation of 5-HMF with Ag foil and oxide-derived Ag (OD-Ag) electrodes [98]. These reactions occurred in $0.5 \mathrm{M}$ borate buffer at $\mathrm{pH}$ of 9.2 and $20 \mathrm{mM}$ of 5 -HMF. Figure $18 \mathrm{a}, \mathrm{b}$ demonstrates the electrolysis setup that was performed in an $\mathrm{H}$-cell and the-electrode flow cell, respectively. At cathodic potential of $-0.51 \mathrm{~V}$ (vs. RHE), 5-HMF conversion and selectivity to 2,5-bis(hydroxymethyl)furan (BHMF) were higher with OD-Ag electrocatalysts instead of Ag foil, and in the flow cell rather than the H-configuration cell. Consequently, this led to the highest 5-HMF conversion of almost $30 \%$, and a selectivity to BHMF of $95.3 \%$ (Figure 18c). 
(a)

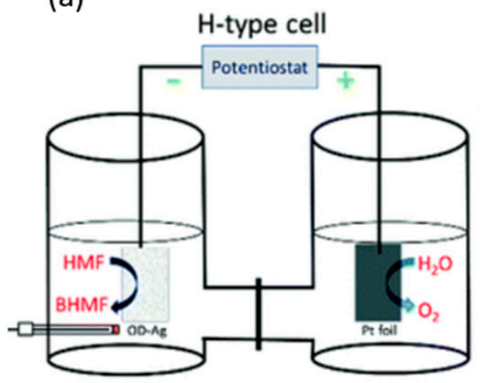

(b)

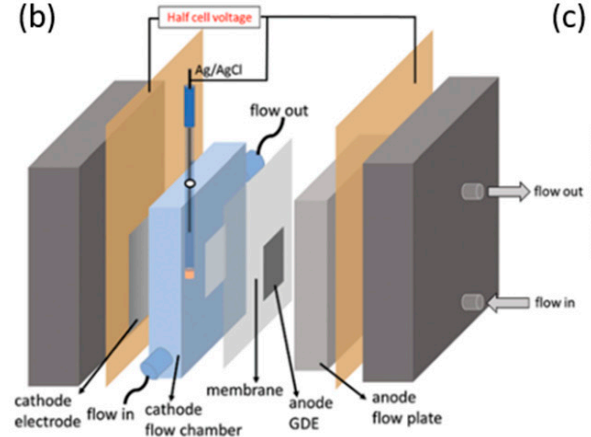

(c)

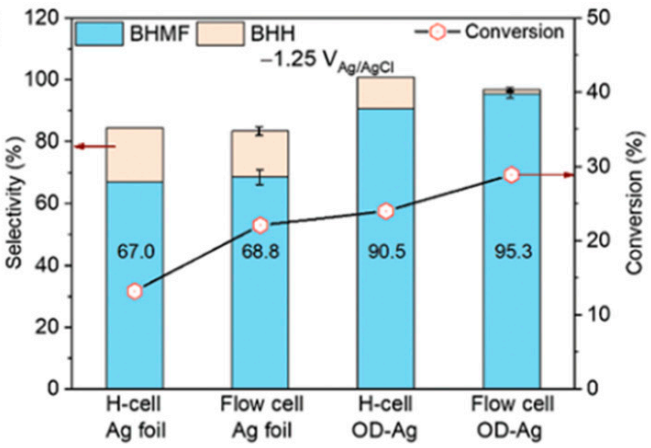

Figure 18. (a) H cell diagram. (b) Flow cell diagram. (c) BMHF and 5,5-bis(hydroxymethyl)hydrofuroin (BHH) results from 5-HMF hydrogenation using Ag or OD-Ag, in H cell or flow cell. Reprinted with permission from Ref. [98]. Copyright 2021, Green Chemistry.

Likewise, using OD-Ag in a flow cell, cathodic hydrogenation of 5-HMF into BHMF was coupled with TEMPO electromediated oxidation of 5-HMF into FDCA at a platinum anode. Overall, the cell energy efficiency of the flow cell was higher than the H-cell, i.e., $24.5 \%$ compared to $5.7 \%$. The resultant selectivity to BHMF was consistently around $90 \%$, accompanied by complete selectivity to FDCA.

\subsection{Levulinic Acid}

Combustion of biofuels could result in zero net carbon release into the atmosphere, representing a greener mode of energy production $[99,100]$. For instance, one example of a biofuel is octane, which can be produced from levulinic acid. The traditional reforming of levulinic acids calls for elevated temperatures and pressures (250-400 ${ }^{\circ} \mathrm{C}$ and $10-35$ bar), which require significant energy resources to sustain [101-103]. Electroreforming levulinic acid might be an attractive alternative for synthesising hydrocarbons for energy generation. This is usually performed at the cathode (reduction) under acidic media, and consists of two steps: the Kolbe reaction and electrocatalytic hydrogenation (ECH), as shown in Figure 19. Several such studies will be explored in this section.<smiles>CC(=O)CCC(=O)O</smiles>

Levulinic acid

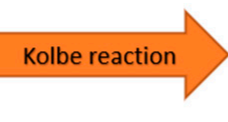<smiles>CC(=O)CCCCC(C)=O</smiles>

2,7-Octadione

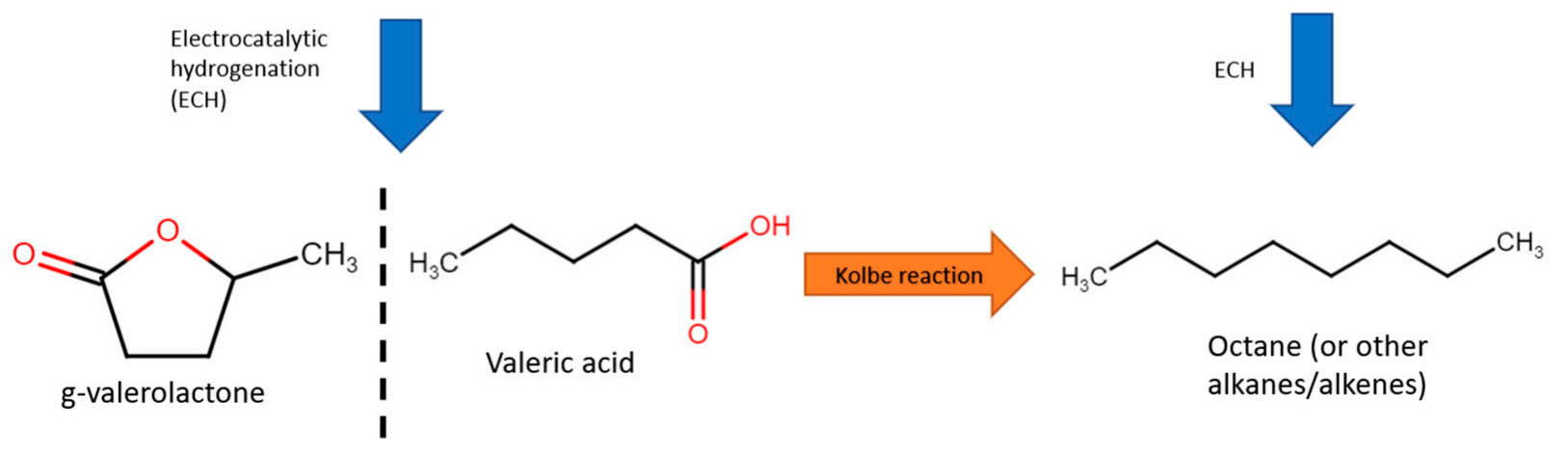

Figure 19. Reaction pathways from levulinic acid to octane. 
In 2012, Nilges et al. first performed ECH of levulinic acid to valeric acid with lead cathode [77]. Valeric acid was then converted to octane via the Kolbe reaction with a Pt cathode. Intially, ECH was performed in $0.5 \mathrm{M}$ sulfuric acid ( $\mathrm{pH}$ of 1 ) and $0.1 \mathrm{M}$ levulinic acid at a fixed $-1.405 \mathrm{~V}$ vs. RHE, with a current density of $20-40 \mathrm{~mA} / \mathrm{cm}^{2}$. With a $\mathrm{Pb}$ electrode, Faradaic efficiency of $27 \%$ and selectivity to valeric acid of $97.2 \%$ were achieved. Subsequently, for the Kolbe step, water and methanol as solvents were compared. Overall, water resulted in better activity, with $40-50 \mathrm{~mA} / \mathrm{cm}^{2}$ at $3.895 \mathrm{~V}$, achieving selectivity of $51.6 \%$ and Faradaic efficiency of $66.5 \%$. In addition, easier extraction of water insoluble products, of which, at $1 \mathrm{M}$ valeric acid and $\mathrm{pH}$ of $5.5,72 \%$ octane selectivity was achieved.

In 2013, Xin et al. studied the electroreforming of levulinic acid to valeric acid and g-valerolactone [104]. Identical to valeric acid, g-valerolactone is an essential precursor to biofuel [105] or can be blended into gasoline directly [106]. The authors compared $\mathrm{CVs}$ of $\mathrm{Cu}$ and $\mathrm{Pb}$ electrodes at $\mathrm{pH}$ of 0 , and found that the onset potential of $\mathrm{Cu}$ was of lower magnitude than that of $\mathrm{Pb}(-0.4 \mathrm{~V}$ vs. $-1.1 \mathrm{~V})$. However, upon adding $0.2 \mathrm{M}$ levulinic acid, onset potential of $\mathrm{Pb}$ increased by $0.2 \mathrm{~V}$ while $\mathrm{Cu}$ displayed little change, suggesting that adsorption of levulinic acid on $\mathrm{Cu}$ was suppressed by fast hydrogen evolution reaction (HER). At low overpotentials $(-1.1 \mathrm{~V})$ with a Pb electrode, conversion of $1.2 \%$ and selectivities towards valeric acid and g-valerolactone of $81.5 \%$ and $18.5 \%$, respectively, were attained. In contrast, higher overpotentials $(-1.5 \mathrm{~V})$ led to conversions of $20.3 \%$ with selectivity of $97 \%$ to valeric acid. Additionally, the effects of $\mathrm{pH}$ were studied by contrasting CVs in $0.5 \mathrm{M}$ sulfuric acid ( $\mathrm{pH}$ of 0 ) and phosphate buffer ( $\mathrm{pH}$ of 7.5). In an acidic medium, this resulted in $94 \%$ selectivity to valeric acid with $12.7 \%$ conversion and $84 \%$ Faradaic efficiency. The opposite behavior in neutral medium was observed with $100 \%$ selectivity to g-valerolactone, although conversion and Faradaic efficiency were low $(1.3 \%$ and $6.2 \%$, respectively).

Xin's and coworkers then constructed a flow cell for continual electrolysis with applied potential fixed at $-1.3 \mathrm{~V}$ (Figure 20a). When operating in the flow cell reactor, higher efficiencies and conversion were recorded accordingly in Figure 20b,c. This was likely due to the high flow rate, which addressed the mass transport issues. Stability tests were conducted across a $20 \mathrm{~h}$ reaction with $0.2 \mathrm{M}$ levulinic acid. Conversion rates were consistent and no $\mathrm{Pb}$ leaching was observed, although the efficiency of Faradaic processes decreased over time.
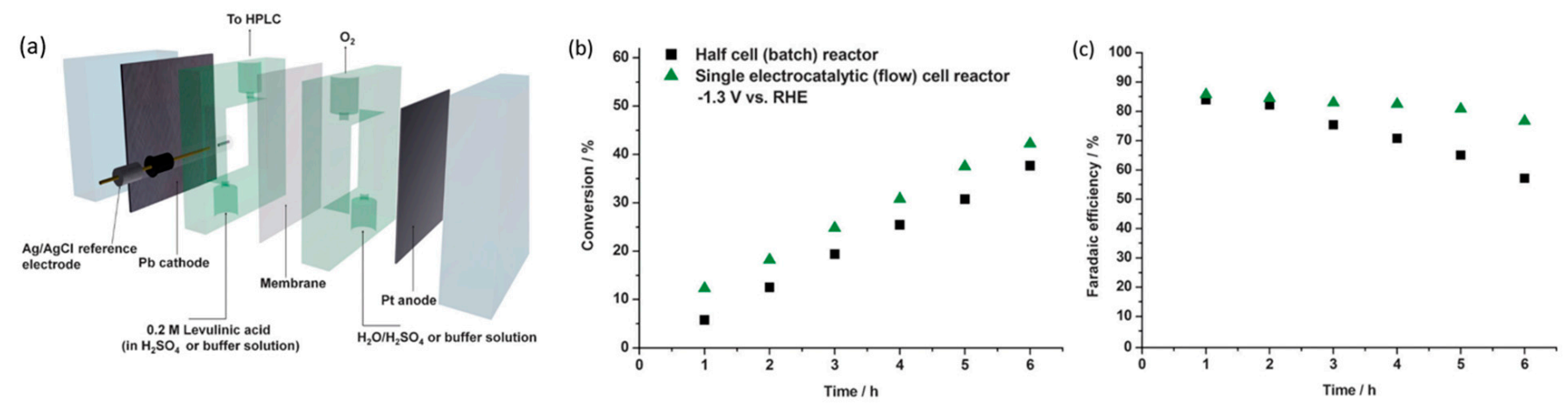

Figure 20. (a) Schematic of flow cell reactor. (b) Comparison of conversion and (c) Faradaic efficiencies of half-cell against flow cell reactor, at $-1.3 \mathrm{~V}, 0.2 \mathrm{M}$ levulinic acid, $0.5 \mathrm{M} \mathrm{H}_{2} \mathrm{SO}_{4}$, with Pb electrode. Reprinted with permission from Ref. [104]. Copyright 2013, ChemSusChem.

In 2015, Dos Santos et al. performed numerous electroreductions of levulinic acid with various electrode materials $(\mathrm{C}, \mathrm{Cu}, \mathrm{Fe}, \mathrm{Ni}, \mathrm{Pb})$ and $\mathrm{pH}$ (acid, alkali or neutral), and compared their products and yields [76]. All ECH was performed at cathodic potentials of $-1.8 \mathrm{~V}$. At a $\mathrm{pH}$ of $0, \mathrm{~Pb}$ resulted in the best yield of valeric acid, with over $70 \%$ conversion and $80 \%$ selectivity to valeric acid. This is likely due to $\mathrm{Pb}$ 's high overpotential for hydrogen evolution, which is the competing reaction at the cathode. On the other hand, using carbon 
in acidic conditions, or Fe in alkali conditions ( $\mathrm{pH}$ of 14) results in g-valerolactone as the major product, with $40 \%$ conversion and selectivities around $70 \%$.

In 2020, Du et al. compared different electrocatalyst materials ( $\mathrm{Pt}, \mathrm{Pb}, \mathrm{Zn}, \mathrm{Ti}, \mathrm{Co}$ and $\mathrm{Cu}$ ) for ECH of levulinic acid to valeric acid [107]. Overall, $\mathrm{Pb}$ showed the best balance of conversion, selectivity, and Faradaic efficiency. Generally, decreasing the applied potential led to higher conversion and selectivity but lower Faradaic efficiency. While reducing $\mathrm{pH}$ led to higher conversion of levulinic acid, it also caused the Faradaic efficiency to decline. As more hydrogen adsorbed on the surface, hydrogen gas formation (via Tafel step or Heyrovsky step) was enhanced. Further LSV scans with different concentration of levulinic acid ( 0 to $0.5 \mathrm{M}$ ) in $0.5 \mathrm{M}$ sulfuric acid showed $\mathrm{ECH}$ of levulinic acid was favored over hydrogen evolution with levulinic acid concentrations above $0.1 \mathrm{M}$. This led to a potential of $-1.15 \mathrm{~V}$ at a current density of $-0.1 \mathrm{~mA} / \mathrm{cm}^{2}$. With elevated temperatures, the overall conversion and rate were increased, and the authors concluded that optimal conditions for $\mathrm{ECH}$ of levulinic acid to valeric acid with $\mathrm{Pb}$ cathode were $0.5 \mathrm{M}$ sulfuric acid with $0.2 \mathrm{M}$ levulinic acid, at $-1.60 \mathrm{~V}$ and $65^{\circ} \mathrm{C}$ over $4 \mathrm{~h}$. Additional stability tests were conducted at room temperature with the mentioned optimal condition, across eight 4-h cycles. Consequently, the selectivity towards valeric acid, Faradaic efficiency, and conversion remained high at $90 \%, 94 \%$ and $48 \%$, respectively.

To support the development of electroreforming on a larger scale, Kurig et al. studied the production of 2,7-octanedione from levulinic acid in a continuous flow single pass reactor [108]. Their setup involved Pt electrodes in $1 \mathrm{M}$ levulinic acid and $0.1 \mathrm{M} \mathrm{KOH}$ as the supporting electrolyte. The optimal residence time (volume of reactor/flow rate) was found to be $36 \mathrm{~min}$, resulting in levulinic acid conversion of $48 \%$ and selectivity of $52 \%$. Unfortunately, even under optimal conditions, the performance of the single pass reactor was poorer than that using a semi batch cell, which could achieve $100 \%$ conversion and $75 \%$ yield. The authors proposed that, for Kolbe electrolysis, localization of radicals was important to promote decarboxylation.

Studies on electroreforming of cellulose and its derivatives at the cathode are summarized in Table 2 with the key technical information. 
Table 2. Studies investigating electroreforming of biomass at the cathode.

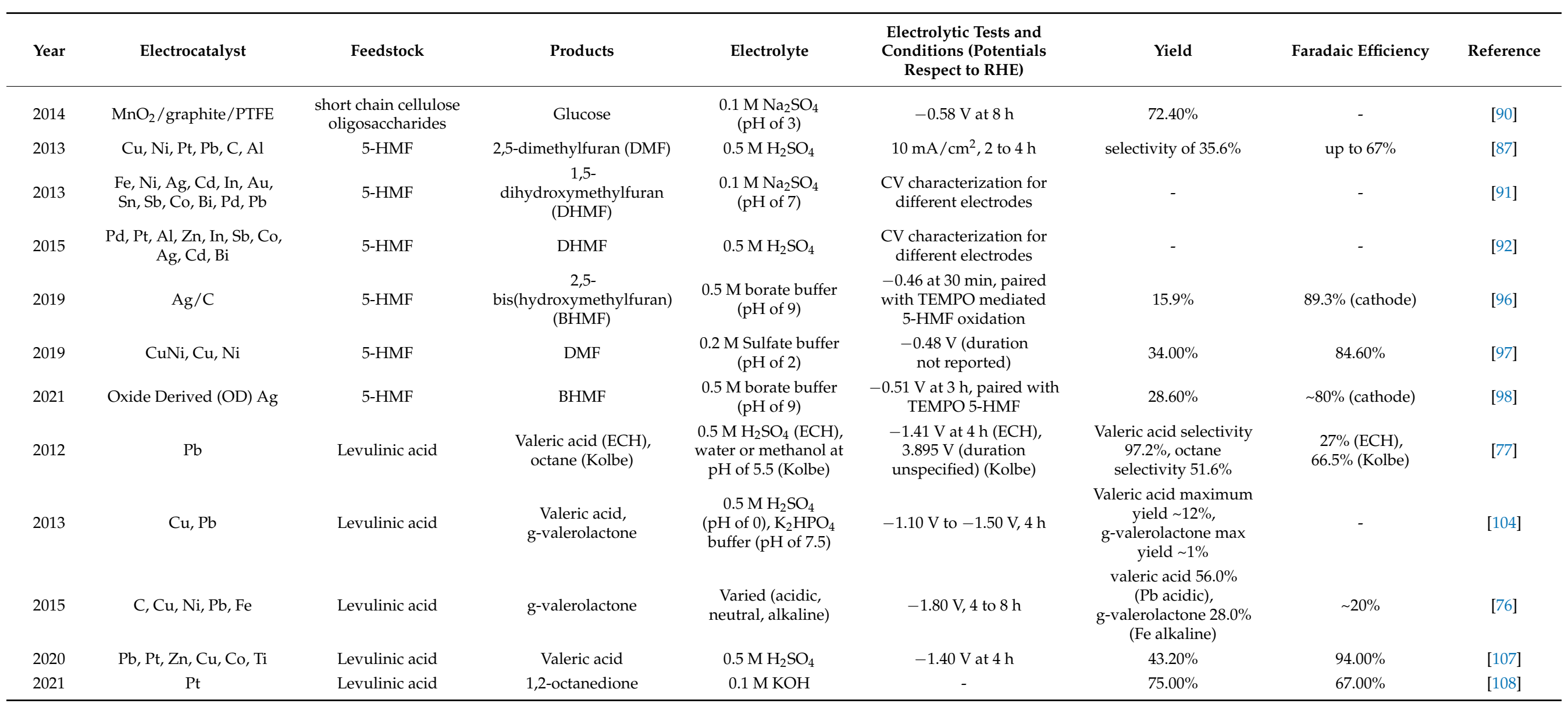




\section{Evolution of Hydrogen Coupled with Biomass Electroreforming}

Owing to the ever-increasing demand for green hydrogen, the decoupling of HER and OER by replacing OER with biomass oxidation has attracted intensive attention recently. Thus, the generation of byproducts of biomass electrooxidation, i.e., green hydrogen, has been intentionally optimized in addition to the enhancement of biomass electrooxidation.

\subsection{Glucose Electrooxidation Coupled with Green Hydrogen Generation}

Using glucose electrooxidation instead of OER to generate green hydrogen for the first time, Du et al. presented the results of their research in 2017 [109]. In their work, iron phosphide films were prepared in situ on stainless steel mesh and used as anodes. The anodic potentials (vs. RHE) to operate at the current density of $10 \mathrm{~mA} / \mathrm{cm}^{2}$ without and with glucose (of $0.5 \mathrm{M}$ concentration) were 1.52 and $1.22 \mathrm{~V}$, respectively, as compared in Figure 21a. No effervescence was observed at the anode, suggesting glucose oxidation completely replaced OER. At a fixed potential of $1.9 \mathrm{~V}$, the hydrogen production rate that coupled to glucose oxidation was higher than that for regular water electrolysis where hydrogen production was coupled to OER, as seen in Figure 21b.

(a)

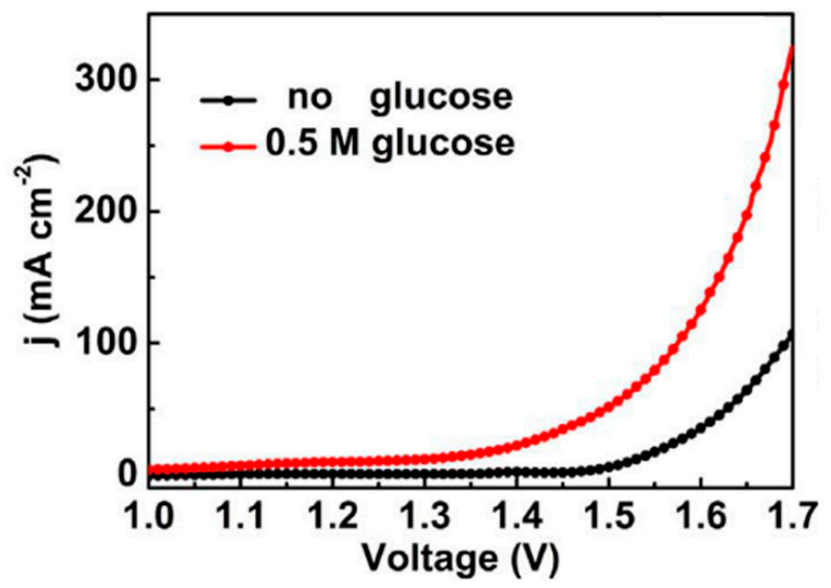

(b)

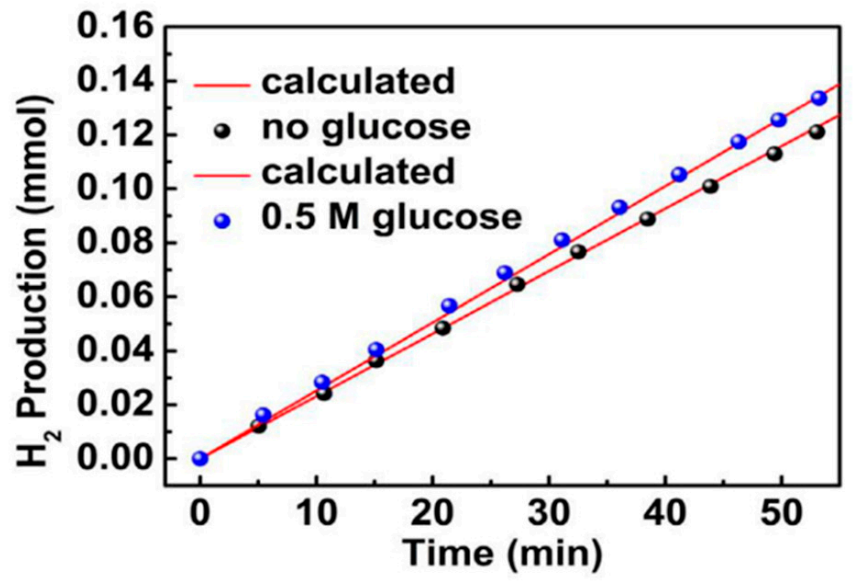

Figure 21. (a) LSV scan in 2-electrode cell without and with $0.5 \mathrm{M}$ glucose in $10 \mathrm{M} \mathrm{KOH}$, iron phosphide anode. (b) Amount of hydrogen theoretically calculated and collected at $1.9 \mathrm{~V}, 10 \mathrm{M} \mathrm{KOH}$ with and without $0.5 \mathrm{M}$ glucose. Reprinted with permission from Ref. [109]. Copyright 2017, Electrochemistry Communications.

In 2019, Rafaïdeen et al. designed Pd-Au nanoparticles on carbon for glucose and xylose oxidation [110] (Figure 22a). The optimal ratio of $\mathrm{Pd}$ to $\mathrm{Au}$ composition was found to be 3:7. In $0.1 \mathrm{M} \mathrm{NaOH}(\mathrm{pH}$ of 13) and $0.1 \mathrm{M}$ glucose, $\mathrm{CV}$ revealed the potential required for $1 \mathrm{~mA} / \mathrm{cm}^{2}$ was $0.2 \mathrm{~V}$, with peak current density $\left(4 \mathrm{~mA} / \mathrm{cm}^{2}\right)$ at $0.5 \mathrm{~V}$. Notably, the conversion of glucose was $67 \%$, and the selectivity to gluconic acid was $87 \%$. Hydrogen production was observed at $\mathrm{Pt} / \mathrm{C}$ cathode without further characterization.

Moreover, the effects of glucose concentration and potentials on the reaction were investigated [111]. Increasing glucose concentration beyond $0.1 \mathrm{M}$ was found to result in lower Faradaic efficiency and chemical yields, suggesting surface poisoning. Unsurprisingly, rate of gluconic acid production was higher with higher voltage, although Faradaic efficiency decreased. The production of hydrogen was estimated by calculating charge transfer to form the measured gluconic acid. It was proposed that, theoretically, 1 ton of $0.1 \mathrm{M}$ glucose could produce $18.47 \mathrm{~kg}$ of hydrogen at $0.6 \mathrm{~V}$ with the setup, consuming $297 \mathrm{kWh}$ electricity. However, it should be noted that this assumes no degradation of electrodes. 


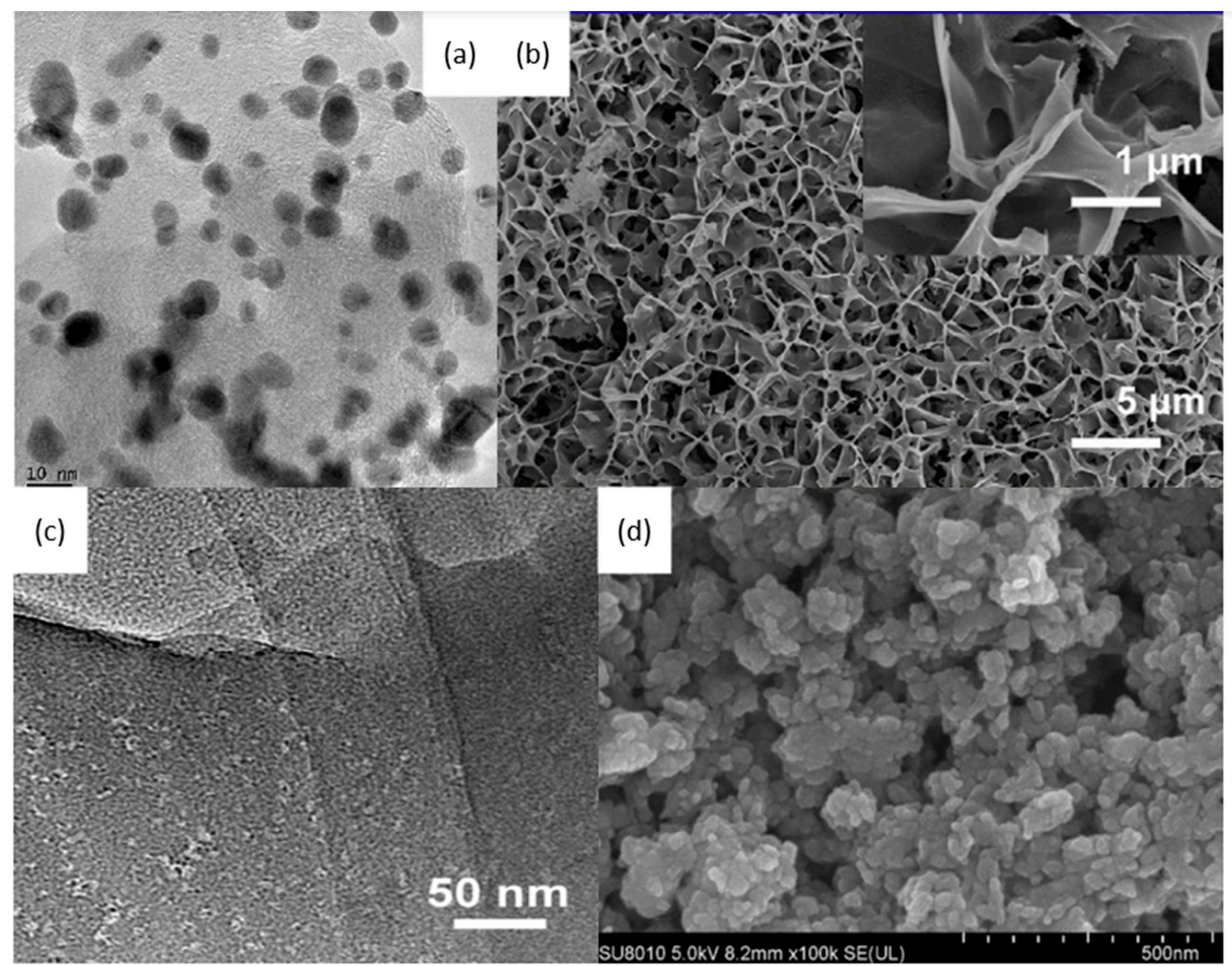

Figure 22. (a) TEM of $\mathrm{Pd}_{3} \mathrm{Au}_{7} / \mathrm{C}$, reprinted with permission from Ref. [110]. Copyright 2019, Applied Catalysis B: Environmental. (b) SEM of Co-Ni alloy, reprinted with permission from Ref. [112]. Copyright 2020, Journal of Alloys and Compounds. (c) $\mathrm{SEM}$ of $\mathrm{Co}_{0.5} \mathrm{Ni}_{0.5}(\mathrm{OH})_{2}$, reprinted with permission from Ref. [113]. Copyright 2020, Journal of Electroanalytical Chemistry. (d) SEM of Ni-MoS 2, reprinted with permission from Ref. [114]. Copyright 2020, International Journal of Hydrogen Energy.

In 2020, Lin et al. investigated the application of Co-Ni alloy electrocatalysts on carbon cloth [112] (Figure 22b). SEM imaging showed significant macropore distribution, and $X$-ray photoelectron spectroscopy characterizations suggested that the partial oxidation of alloy occurred. Additional LSV determined the potential for $10 \mathrm{~mA} / \mathrm{cm}^{2}$ on Co-Ni alloy electrode to be $1.096 \mathrm{~V}$ in $1 \mathrm{M} \mathrm{KOH}$ with $0.1 \mathrm{M}$ glucose, which was less than those on the bulk Co $(1.143 \mathrm{~V})$ or $\mathrm{Ni}(1.138 \mathrm{~V})$ electrodes. Further electrochemical impedance spectroscopy (EIS) measurement and Tafel slope comparisons among Co, Ni and Co-Ni alloy electrodes showed the superior conductivity and kinetics of the alloy electrode. In a two-electrode cell with Co-Ni alloy, both electrodes achieved $10 \mathrm{~mA} / \mathrm{cm}^{2}$ at a voltage of only $1.39 \mathrm{~V}$ in $1 \mathrm{M} \mathrm{KOH}$ with $0.1 \mathrm{M}$ glucose.

Lin and coworkers also used a customized cobalt nickel hydroxide nanosheet $\left(\mathrm{Co}_{0.5}\right.$ $\left.\mathrm{Ni}_{0.5}(\mathrm{OH})_{2} \mathrm{NS}\right)$ on carbon cloth as the anode, and replaced OER with glucose oxidation [113] (Figure 22c). $\mathrm{Co}_{0.5} \mathrm{Ni}_{0.5}(\mathrm{OH})_{2} \mathrm{NS}$ electrode measured potential of $1.17 \mathrm{~V}$ at current density of $10 \mathrm{~mA} / \mathrm{cm}^{2}$. After a $12 \mathrm{~h}$ reaction at constant current density, the potential increased slightly to $1.20 \mathrm{~V}$, indicating superior electrode stability. In a two-electrode cell with Pt cathode, the required potentials for 10 and $100 \mathrm{~mA} / \mathrm{cm}^{2}$ in $1 \mathrm{M} \mathrm{KOH}$ only were 1.47 and $1.75 \mathrm{~V}$, respectively. With the addition of $0.1 \mathrm{M}$ glucose, the corresponding potentials decreased to $1.22 \mathrm{~V}$ and $1.56 \mathrm{~V}$, respectively. 
Similarly, Liu et al. fabricated nickel-molybdenum disulfide $\left(\mathrm{Ni}-\mathrm{MoS}_{2}\right)$ for both anode and cathode [114] (Figure 22d). LSV showed the potentials needed for $10 \mathrm{~mA} / \mathrm{cm}^{2}$ in $1 \mathrm{M}$ $\mathrm{KOH}$ without and with $0.3 \mathrm{M}$ glucose were 1.64 and $1.46 \mathrm{~V}$, respectively. Additional Tafel slopes, EIS spectra, and double layer capacitance characterizations revealed preferable kinetics and catalytic activity of Ni-MoS 2 compared to $\mathrm{MoS}_{2}$ and $\mathrm{Pt} / \mathrm{C}$, as well as good stability through $12 \mathrm{~h}$ chronoamperometric tests. Subsequently, a two-electrode cell was constructed with $\mathrm{Ni}-\mathrm{MoS}_{2}$ on carbon paper as both the anode and cathode, and $1.67 \mathrm{~V}$ was required to reach $10 \mathrm{~mA} / \mathrm{cm}^{2}$. No bubbles were observed the anode, suggesting complete suppression of OER.

Zheng et al. used iron-doped cobalt diselenide nanowires on conductive carbon cloth $\left(\mathrm{Fe}_{0.1}-\mathrm{CoSe}_{2} / \mathrm{CC}\right)$ as an alkaline anode and acidic cathode to produce gluconate (salt of gluconic acid) and hydrogen, respectively [115] (Figure 23a). For a glucose oxidation reaction in $1 \mathrm{M} \mathrm{KOH}$, LSV scans reveal that a $\mathrm{Fe}_{0.1}-\mathrm{CoSe}_{2} / \mathrm{CC}$ electrode with and without $0.5 \mathrm{M}$ glucose necessitated voltages of $1.65 \mathrm{~V}$ and $1.12 \mathrm{~V}$, respectively, as shown in Figure 23b. With glucose, no bubbles were observed at the anode, suggesting complete suppression of OER. Moreover, the chronopotentiometric scans showed stable potential responses, signifying stable mass transport properties. The stability of the electrode was confirmed by XRD and morphological scans taken before and after $8 \mathrm{~h}$ of electrolysis at $1.15 \mathrm{~V}$, showing no sign of differences.
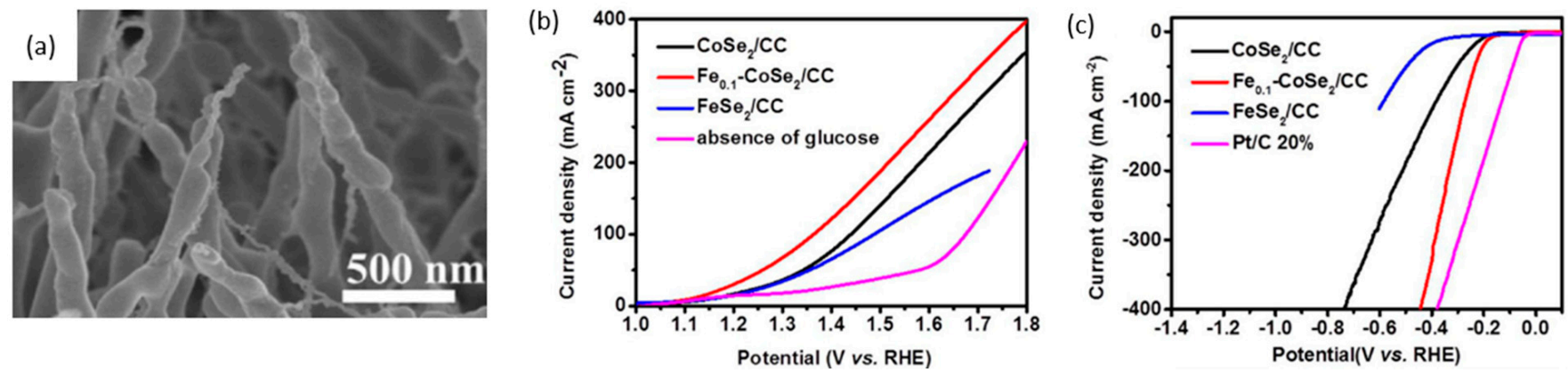

Figure 23. (a) SEM image of $\mathrm{Fe}_{0.1} \mathrm{CoSe}_{2}$ /CC. (b) LSV for anodic glucose oxidation, $1 \mathrm{M} \mathrm{KOH}, 0.5 \mathrm{M}$ glucose with different electrodes. (c) LSV for cathodic hydrogen evolution, $0.5 \mathrm{M} \mathrm{H}_{2} \mathrm{SO}_{4}$. Reprinted with permission from Ref. [115]. Copyright 2020, Applied Catalysts B: Environmental.

The authors also analyzed cathodic hydrogen evolution using $\mathrm{Fe}_{0.1}-\mathrm{CoSe}_{2} / \mathrm{CC}$ in $0.5 \mathrm{M}$ $\mathrm{H}_{2} \mathrm{SO}_{4}$, and found that overpotential of $270 \mathrm{mV}$ was required to reach a current density of $100 \mathrm{~mA} / \mathrm{cm}^{2}$ (Figure 23c). Similar tests were conducted to confirm catalytic activity and electrode stability. A two-electrode cell was constructed with a bipolar membrane separating $1 \mathrm{M} \mathrm{KOH}$ anolyte and $0.5 \mathrm{M} \mathrm{H}_{2} \mathrm{SO}_{4}$ catholyte. To reach $10 \mathrm{~mA} / \mathrm{cm}^{2}$, the cell potential in the absence of glucose was applied at $1.34 \mathrm{~V}$, which decreased to $0.72 \mathrm{~V}$ with the addition of $0.5 \mathrm{M}$ glucose. For generating green hydrogen, the cell was maintained at $10 \mathrm{~mA} / \mathrm{cm}^{2}$, with $1 \mathrm{M} \mathrm{KOH}, 0.5 \mathrm{M}$ glucose at the anode and $0.5 \mathrm{M} \mathrm{H}_{2} \mathrm{SO}_{4}$ at the cathode. Performing chronopotentiometric electrolysis for 100 min yielded $0.15 \mathrm{mmol}$ of $\mathrm{H}_{2}$ with 99\% Faradaic efficiency.

Ding et al. further proposed that in order for hydrogen electrolysis to be truly green, electrodes should be part of a closed material cycle [116]. Interestingly, they developed carbon electrodes from biowaste to replace OER with carbon oxidation, intending for the carbon anode to be consumed in the process. Rather than electrolyzing glucose in solution, the authors fabricated carbon pellets (Figure 24a) by means of hydrothermal treatment of glucose, which were deposited onto glassy carbon electrodes. The two-electrode cell potential was fixed at $2.4 \mathrm{~V}$, and the sacrificial carbon anode and Pt cathode were deployed. This anode was maintained at a $\mathrm{pH}$ of 13 , and the carbon anode was oxidized to carbonate, allowing continuous hydrogen formation at the cathode. The test cell was left to run for 10 days, and the products were quantified (Figure 24b). Doping carbon pellets with nitrogen 
resulted in better anode stability without influencing electrode conductivity or hydrogen production, as seen in the higher $\mathrm{H}_{2}$ evolution after 10 days in Figure 24c compared to that without nitrogen doping in Figure 24b.
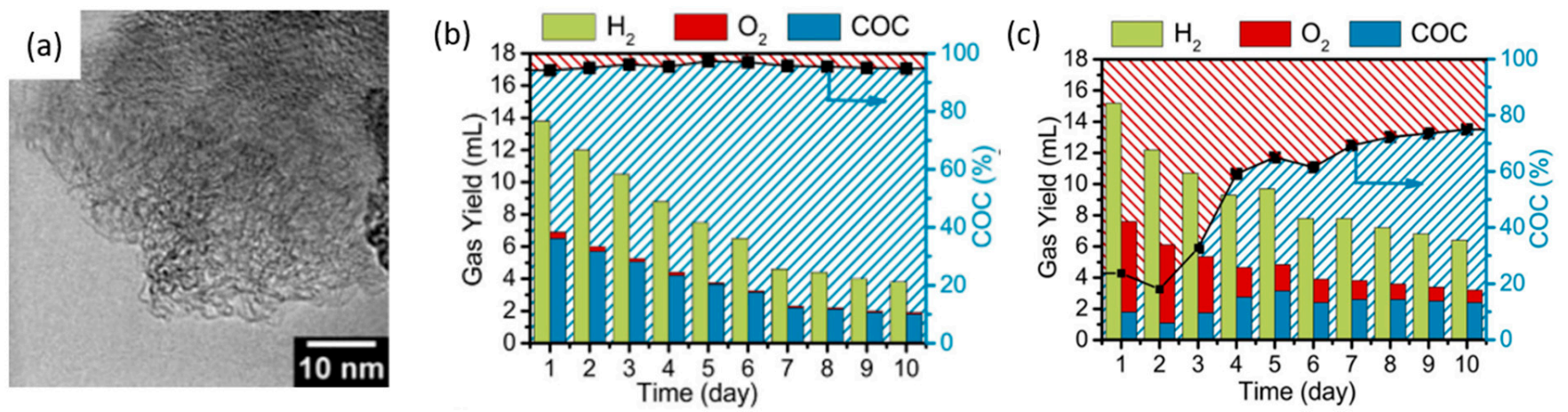

Figure 24. (a) SEM image of carbon pellet. (b) Hydrogen production over days, from carbon oxidation contribution (COC) or oxygen evolution, with a carbon electrode. (c) Hydrogen production under similar conditions with a nitrogen-doped carbon electrode. Reprinted with permission from Ref. [116]. Copyright 2020, ChemSusChem.

\subsection{5-HMF Electrooxidation Coupled with Green Hydrogen Generation}

5-HMF electrooxidation can also replace OER for safe green hydrogen generation. Yang et al. explored the electroreforming of 5-HMF and simultaneous hydrogen production [117] using Mo-doped nickel selenides on Ni foam (Mo-Ni $\left.{ }_{0.85} \mathrm{Se} / \mathrm{NF}\right)$. With Mo$\mathrm{Ni}_{0.85} \mathrm{Se} / \mathrm{NF}$ as both electrodes, in $1 \mathrm{M} \mathrm{KOH}$, to achieve current density of $50 \mathrm{~mA} / \mathrm{cm}^{2}$, adding $10 \mathrm{mM}$ 5-HMF reduced the overall potential from 1.68 to $1.50 \mathrm{~V}$. At an anodic potential of $1.4 \mathrm{~V}$, complete conversion was observed, and Faradaic efficiency and selectivity were both high at $>95 \%$, while $3.8 \mathrm{mmol}$ of hydrogen was produced with a Faradaic efficiency close to $100 \%$ at the cathode. The authors proposed Mo doping changed the $\mathrm{d}$-band centre of $\mathrm{Ni}$ and reduced the hydrogen adsorption energy on electrode surface, increasing electrocatalytic activity.

Jiang et al. used Co-P catalysts on $\mathrm{Cu}$ foam for concurrent anodic oxidation of 5-HMF into FDCA and cathodic reduction of water to $\mathrm{H}_{2}$ [118]. In $1 \mathrm{M} \mathrm{KOH}$, anodic potential required for current density of $20 \mathrm{~mA} / \mathrm{cm}^{2}$ decreased from 1.53 to $1.38 \mathrm{~V}$ upon addition of $50 \mathrm{mM}$ 5-HMF. From periodic HPLC analysis during anodic reaction process, suggesting that FDCA is obtained through DFF route (see Figure 10 for reaction pathways). The authors then employed a two-electrode cell for concurrent anodic 5-HMF oxidation and cathodic hydrogen evolution. In $1 \mathrm{M} \mathrm{KOH}$ and using $\mathrm{Co}-\mathrm{P} / \mathrm{Cu}$ foam electrodes, the overall potential required for $20 \mathrm{~mA} / \mathrm{cm}^{2}$ decreased from 1.59 to $1.44 \mathrm{~V}$ after adding $50 \mathrm{mM} 5-\mathrm{HMF}$ (Figure 25a). In this case, 100\% 5-HMF conversion and 90\% FDCA yield were measured at the anode, while $8 \mathrm{mmol}$ of hydrogen gas was produced with $100 \%$ Faradaic efficiency at the cathode, as depicted in Figure 25b. 

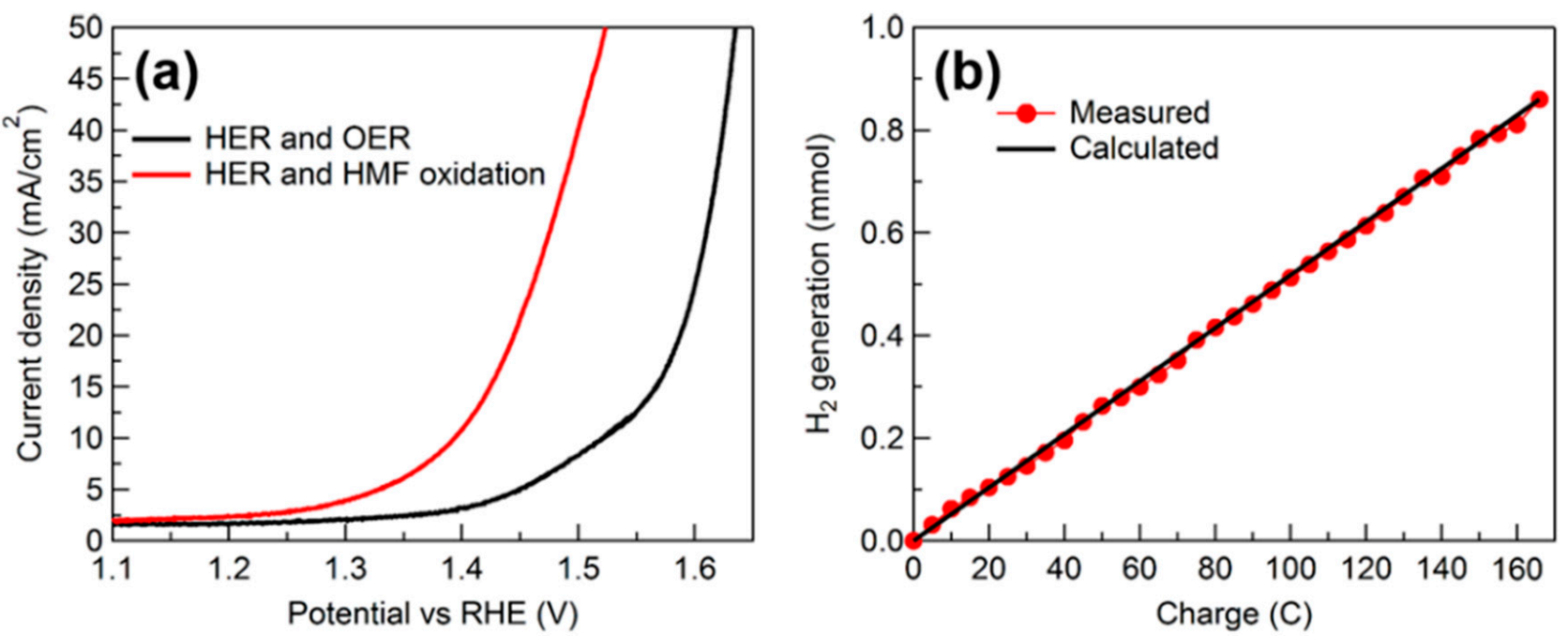

Figure 25. (a) LSV of two-electrode cell for concurrent 5-HMF oxidation and hydrogen evolution. (b) Amount of hydrogen theoretically calculated and measured at the cathode. Reprinted with permission from Ref. [118]. Copyright 2016, ACS Energy Letters.

Combining $\mathrm{Ni}$ and vanadium oxides was found to enhance charge redistribution and weaken hydrogen adsorption on $\mathrm{Ni}$, which would otherwise limit catalytic activity [119]. Thus, Liang et al. fabricated a nickel nitride-vanadium trioxide $\left(\mathrm{Ni}_{3} \mathrm{~N}-\mathrm{V}_{2} \mathrm{O}_{3}\right)$ catalyst for 5-HMF oxidation and hydrogen evolution [120]. The cathodic performance of $\mathrm{Ni}_{3} \mathrm{~N}_{-}-\mathrm{V}_{2} \mathrm{O}_{3}$ was superior to only $\mathrm{Ni}_{3} \mathrm{~N}$ or $\mathrm{V}_{2} \mathrm{O}_{3}$, and on par with $\mathrm{Pt} / \mathrm{C}$, as shown in Figure 26a. At the anode, $\mathrm{Ni}_{3} \mathrm{~N}-\mathrm{V}_{2} \mathrm{O}_{3}$ was similarly more active than $\mathrm{Ni}_{3} \mathrm{~N}$, and addition of $10 \mathrm{mM}$ 5-HMF reduced overpotentials by about $0.14 \mathrm{~V}$. Adding 5-HMF also caused the disappearance of oxidation peak of $\mathrm{Ni}^{2+}$ to $\mathrm{Ni}^{3+}$ before water splitting (Figure 26b). Experiments were performed using a two-electrode cell (both anode and cathode being $\mathrm{Ni}_{3} \mathrm{~N}-\mathrm{V}_{2} \mathrm{O}_{3}$ ) in $1 \mathrm{M}$ $\mathrm{KOH}$ with $10 \mathrm{mM} 5-\mathrm{HMF}$, at a fixed current of $10 \mathrm{~mA} / \mathrm{cm}^{2}$ with corresponding overall potential of about $1.4 \mathrm{~V}$. FDCA yield of $96.1 \%$ and selectivity of $98.7 \%$, and hydrogen Faradaic efficiency of over 90\% were reported, as shown in Figure 26c,d.

(a)

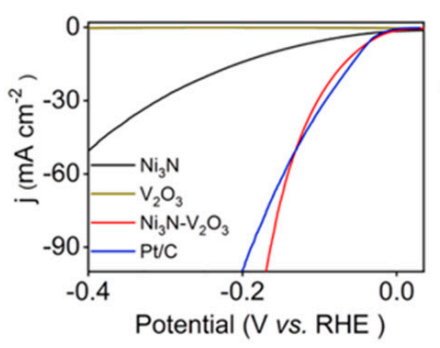

(b)

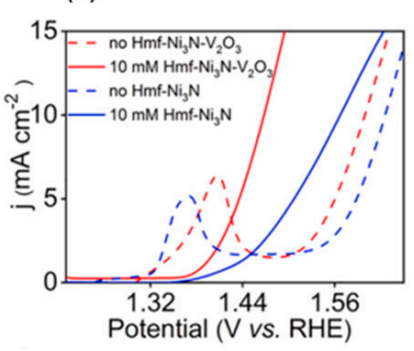

(c)

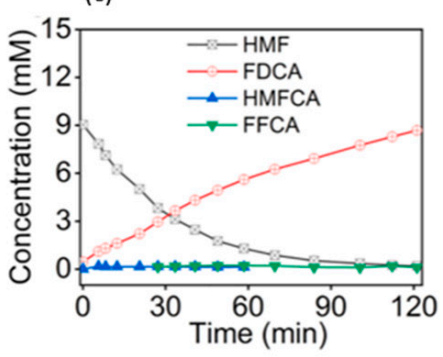

(d)

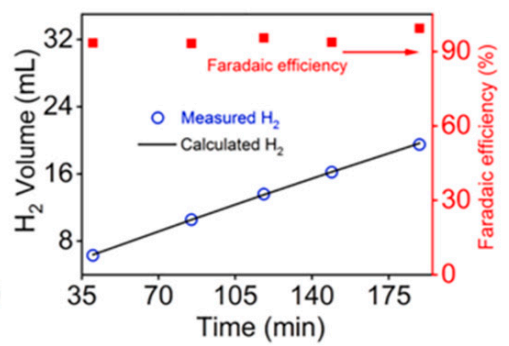

Figure 26. (a) LSV for $\mathrm{Ni}_{3} \mathrm{~N}-\mathrm{V}_{2} \mathrm{O}_{3}, \mathrm{Ni}_{3} \mathrm{~N}, \mathrm{~V}_{2} \mathrm{O}_{3}$ and $\mathrm{Pt} / \mathrm{C}$ cathodes. (b) LSV for $\mathrm{Ni}_{3} \mathrm{~N}-\mathrm{V}_{2} \mathrm{O}_{3}$ and $\mathrm{Ni}_{3} \mathrm{~N}$ anodes with and without $10 \mathrm{mM}$ 5-HMF. (c) Concentrations of 5-HMF and products over time, in two-electrode test cell, $1 \mathrm{M} \mathrm{KOH}, 10 \mathrm{mM}$ 5-HMF, chronopotentiometric test at $10 \mathrm{~mA} / \mathrm{cm}^{2}, \mathrm{Ni}_{3} \mathrm{~N}_{-} \mathrm{V}_{2} \mathrm{O}_{3}$ anode and cathode. (d) Theoretical and actual production of hydrogen gas. Reprinted with permission from Ref. [120]. Copyright 2021, Chemical Engineering Journal.

Studies on evolution of hydrogen coupled with biomass electroreforming are summarized in Table 3 with the key technical information. 
Table 3. Studies investigating evolution of hydrogen coupled with biomass electroreforming.

\begin{tabular}{|c|c|c|c|c|c|c|c|c|c|}
\hline Year & Electrocatalyst & Feedstock & $\begin{array}{l}\text { Desired } \\
\text { Product(s) }\end{array}$ & $\begin{array}{l}\text { Electrolyte } \\
\text { (Catholyte) }\end{array}$ & $\begin{array}{l}\text { Electrolytic } \\
\text { Conditions }\end{array}$ & $\begin{array}{l}\text { Coupled Product } \\
\text { Yield (If Any) }\end{array}$ & OER Potential & $\begin{array}{c}\text { Reactant } \\
\text { Oxidation } \\
\text { Potential }\end{array}$ & Reference \\
\hline 2017 & $\mathrm{Fe}_{2} \mathrm{P} /$ Stainless steel mesh & $0.5 \mathrm{M}$ glucose & Hydrogen & $10 \mathrm{M} \mathrm{KOH}$ & $\mathrm{CV}$ characterization & - & $\begin{array}{l}1.52 \mathrm{~V} \text { for } \\
10 \mathrm{~mA} / \mathrm{cm}^{2}\end{array}$ & $\begin{array}{c}1.22 \mathrm{~V} \text { for } \\
10 \mathrm{~mA} / \mathrm{cm}^{2}\end{array}$ & [109] \\
\hline 2019 & $\mathrm{Pd}-\mathrm{Au} / \mathrm{C}$ & $0.1 \mathrm{M}$ glucose & $\begin{array}{l}\text { Hydrogen, } \\
\text { gluconic acid }\end{array}$ & $0.1 \mathrm{M} \mathrm{NaOH}$ & $\begin{array}{l}\mathrm{CV} \text { characterization, } \\
\text { applied } 0.40 \mathrm{~V} \text { at } 6 \mathrm{~h}\end{array}$ & $\begin{array}{c}\text { Gluconate yield } \\
58.3 \%\end{array}$ & 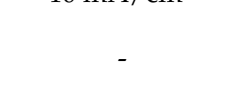 & $\begin{array}{c}0.2 \mathrm{~V} \text { for } 1 \\
\mathrm{~mA} / \mathrm{cm}^{2}, 0.5 \mathrm{~V} \text { for } \\
\mathrm{max} 4 \mathrm{~mA} / \mathrm{cm}^{2}\end{array}$ & [110] \\
\hline 2020 & $\mathrm{Co}, \mathrm{Ni}, \mathrm{Co}-\mathrm{Ni} /$ Carbon cloth & $0.1 \mathrm{M}$ glucose & Hydrogen & $1 \mathrm{M} \mathrm{KOH}$ & $\mathrm{CV}$ characterization & - & $\begin{array}{l}1.39 \mathrm{~V} \text { for } \\
10 \mathrm{~mA} / \mathrm{cm}^{2}\end{array}$ & $\begin{array}{c}1.096 \mathrm{~V} \text { for } \\
10 \mathrm{~mA} / \mathrm{cm}^{2}\end{array}$ & [112] \\
\hline 2020 & $\mathrm{Ni}-\mathrm{MoS}_{2} /$ carbon paper & $0.3 \mathrm{M}$ glucose & Hydrogen & $1 \mathrm{M} \mathrm{KOH}$ & $\mathrm{CV}$ characterization & - & $\begin{array}{l}1.64 \mathrm{~V} \text { for } \\
10 \mathrm{~mA} / \mathrm{cm}^{2}\end{array}$ & $\begin{array}{l}1.46 \mathrm{~V} \text { for } \\
10 \mathrm{~mA} / \mathrm{cm}^{2}\end{array}$ & [114] \\
\hline 2020 & $\mathrm{Fe}_{0.1}-\mathrm{CoSe}_{2} /$ Carbon cloth & 0.5 M glucose & $\begin{array}{l}\text { Hydrogen, } \\
\text { gluconic acid }\end{array}$ & $0.5 \mathrm{M} \mathrm{H}_{2} \mathrm{SO}_{4}$ & $\mathrm{CV}$ characterization & - & $\begin{array}{c}1.34 \mathrm{~V} \text { for } \\
10 \mathrm{~mA} / \mathrm{cm}^{2}\end{array}$ & $\begin{array}{c}0.72 \mathrm{~V} \text { for } \\
10 \mathrm{~mA} / \mathrm{cm}^{2}\end{array}$ & [115] \\
\hline 2020 & $\begin{array}{l}\text { glucose derived } \\
\text { carbon/glassy carbon }\end{array}$ & $\begin{array}{c}\text { sacrificial } \\
\text { carbon at cathode }\end{array}$ & Hydrogen & $0.1 \mathrm{M} \mathrm{KOH}$ & $\mathrm{CV}$ characterization & - & OER onset $1.52 \mathrm{~V}$ & $\begin{array}{l}\text { Carbon oxidation } \\
\text { onset } 1.02 \mathrm{~V}\end{array}$ & [116] \\
\hline 2021 & Mo-Ni0.85Se/NF & $10 \mathrm{mM}$ 5-HMF & Hydrogen, FDCA & $1 \mathrm{M} \mathrm{KOH}$ & $1.40 \mathrm{~V}$ at $2 \mathrm{~h}$ & $\begin{array}{l}\text { FDCA yield } 95.0 \%, \\
\text { FE } 95.0 \%\end{array}$ & $\begin{array}{l}\text { Overall } 1.68 \mathrm{~V} \text { for } \\
50 \mathrm{~mA} / \mathrm{cm}^{2}\end{array}$ & $\begin{array}{l}\text { Overall } 1.5 \mathrm{~V} \text { for } \\
50 \mathrm{~mA} / \mathrm{cm}^{2}\end{array}$ & [117] \\
\hline 2016 & $\mathrm{Co}-\mathrm{P} / \mathrm{Cu}$ foam & $50 \mathrm{mM}$ 5-HMF & Hydrogen, FDCA & $1 \mathrm{M} \mathrm{KOH}$ & $1.42 \mathrm{~V}$ at $6 \mathrm{~h}$ & FDCA yield $90.0 \%$ & $\begin{array}{l}\text { Anodic } 1.53 \mathrm{~V}, \\
\text { overall } 1.59 \mathrm{~V} \text { for } \\
20 \mathrm{~mA} / \mathrm{cm}^{2}\end{array}$ & $\begin{array}{c}\text { anodic } 1.38 \mathrm{~V}, \\
\text { overall } 1.44 \mathrm{~V} \text { for } \\
20 \mathrm{~mA} / \mathrm{cm}^{2}\end{array}$ & [118] \\
\hline 2021 & $\mathrm{Ni}_{3} \mathrm{~N}-\mathrm{V}_{2} \mathrm{O}_{3}$ & $10 \mathrm{mM}$ 5-HMF & Hydrogen, FDCA & $1 \mathrm{M} \mathrm{KOH}$ & $10 \mathrm{~mA} / \mathrm{cm}^{2}$ at $112 \mathrm{~min}$ & FDCA yield $96.1 \%$ & - & $\begin{array}{c}1.4 \mathrm{~V} \text { for } \\
10 \mathrm{~mA} / \mathrm{cm}^{2}\end{array}$ & [120] \\
\hline
\end{tabular}




\section{Conclusions and Outlook}

The electroreforming of biomass compounds represents a promising green and sustainable route for synthesizing value-added chemicals with minimum damage to the environment. Compared to thermochemical routes, the operating conditions of electroreforming route are usually milder, and product controllability is better through tuning electrolytic cell parameters such as $\mathrm{pH}$ and potential. When compared to the biochemical routes, electroreforming processes can be conducted in more compact devices and in much shorter durations. For electroreforming of cellulose derivatives (glucose, 5-HMF, levulinic acid), exciting progress has been made by using various metal electrocatalysts to improve products and yields. In particular, recent studies have demonstrated the usage of non-noble metals or bimetallic alloys as electrocatalysts for both oxidation and hydrogenation processes. These developments shift reliance away from expensive noble metals, potentially increasing the economic viability of electroreforming techniques. Studies of flow reactor cells $[54,67,98,108]$, showcased the possible continual production they provide, and therefore their industrial scalability. Notably, a great advantage of the electrochemical route is the cogeneration of green hydrogen, which plays an indispensable role in decarbonization. From an energy saving prospective, both holes and electrons from electricity are utilized in such hybrid electrolysis, coupling biomass electrooxidation and water reduction, leading to valuable cathodic and anodic products. Despite these promising advantages of biomass electroreforming over state-of-the-art biomass valorization, there are challenges to tackle before large-scale implementation.

Investigations into direct electroreforming of cellulose remains under-represented mainly due to the large polymer that could not be readily hydrolyzed in electrolyte. In order to make every stage in electroreforming pipeline green and sustainable, glucose and the other derivatives should be obtained from cellulose, so as not to compete with edible plant sources. At the time of writing, several studies have been published to uncover electrooxidation and depolymerization mechanisms of cellulose. A few studies have analyzed useful products from cellulose electrolysis [36]. Thus, more investigations into energy-efficient and cost-effective pre-treatment methods are needed for converting raw biomass polymers to smaller molecules that can be readily reformed by electrochemical process. To this end, the rational combination of mechanochemical and biological processes could potentially hold great promise.

High-value products would offset the overall production cost, increasing the economic viability of the electroreforming route. Raw biomass consists of large polymers and selectively converting them to high-value products is challenging. Ideally, one would like to get all possible reaction pathways and products mapped out, and then study how to control the selectivity. Therefore, in situ/operando measurements such as FTIR and SERS-based optical methods are promising approaches to shed light on the detailed reaction mechanisms. Moreover, complementary theoretical models to predict the thermodynamics and kinetics of the reaction are critical for a complete understanding of the reactions involved in electroreforming. Nevertheless, atomic modeling of large polymer necessitates superior computing facilities and is very costly. As studies performed by Roman et al. have shown, in situ methods such as spectroscopy can be combined with simulations for density functional theory calculations to provide enhanced understanding of reaction mechanisms [89]. A rational combination of in situ/operando characterization and theoretical modeling could lead to time- and energy-efficient investigation without compromising accuracy.

Studies were also mostly focused on exploring the feasibility of different advanced catalysts and electrodes. It is noted that most reported catalysts show superior activity but inferior stability, which is very crucial for practical use. Many lessons can be learnt from the development of water electrolysis across the full $\mathrm{pH}$ range. Alkaline water electrolysis is by far the cheapest and most scalable technique for green hydrogen generation. Despite the recent drastic reduction in its cost, PEM water electrolysis still suffers from poor scalability mainly due to its Pt-group catalysts, particularly its anodic catalyst based on iridium and ruthenium. Similar challenge faces biomass electroreforming in acidic 
media. To this end, strategies for stabilizing non-precious catalyst and decreasing load of precious catalysts for PEM water electrolysis can be implemented for acidic biomass electroreforming. Nevertheless, biomass electroreforming in alkaline media is still relatively more cost-effective and scalable. Electroreforming of biomass represents a greener route of electrosynthesis of chemicals. Despite its advantage of better sustainability, it is challenging to control the reaction pathways. Advanced catalyst design, e.g., tandem catalysts, could enrich the toolbox of pathways for biomass electroreforming.

Lastly, in order to advance our collective understanding, forming a consistent benchmark on evaluating the efficacy of different designs will be critical. A standard protocol with critical parameters, such as potential, current density, and stability, for benchmarking is needed before one can compare the results across the literature. Such benchmarking will greatly facilitate the development of catalysts and electrodes.

Author Contributions: Conceptualization, H.L.; literature review, Z.I.L., L.Q.L.; writing一original draft preparation, Z.I.L.; writing-review and editing, H.L., Z.I.L., L.Q.L.; supervision, H.L.; project administration, H.L. All authors have read and agreed to the published version of the manuscript.

Funding: This work was funded by A*STAR Science and Engineering Research Council AME IRG funding (A1983c0029) and MOE Tier 1 (RG58_21).

Acknowledgments: L.Q.L. would like to thank Nanyang Technological University for Research Scholarship under Nanyang Environment and Water Research Institute/Interdisciplinary Graduate Programme (NEWRI/IGP).

Conflicts of Interest: The authors declare no conflict of interest.

\section{References}

1. IPCC. Global warming of $1.5^{\circ} \mathrm{C}$. An IPCC Special Report on the Impacts of Global Warming of $1.5^{\circ} \mathrm{C}$ above Pre-Industrial Levels and Related Global Greenhouse Gas Emission Pathways, in the Context of Strengthening the Global Response to the Threat of Climate Change. IPCC Sr15, October 2, pp. 17-20. 2018. Available online: www.environmentalgraphiti.org (accessed on 11 August 2021).

2. IPCC. Climate Change 2021: The Physical Science Basis. Contribution of Working Group I to the Sixth Assessment Report of the Intergovernmental Panel on Climate Change; Cambridge University Press: Cambridge, UK, 2021.

3. Jevrejeva, S.; Jackson, L.P.; Grinsted, A.; Lincke, D.; Marzeion, B. Flood damage costs under the sea level rise with warming of $1.5^{\circ} \mathrm{C}$ and $2{ }^{\circ} \mathrm{C}$. Environ. Res. Lett. 2018, 13, 074014. [CrossRef]

4. Gasparrini, A.; Guo, Y.; Sera, F.; Vicedo-Cabrera, A.M.; Huber, V.; Tong, S. Projections of temperature-related excess mortality under climate change scenarios. Lancet Planet. Health 2017, 1, e360-e367. [CrossRef]

5. Deryng, D.; Conway, D.; Ramankutty, N.; Price, J.; Warren, R. Global crop yield response to extreme heat stress under multiple climate change futures. Environ. Res. Lett. 2014, 9, 034011. [CrossRef]

6. Mehran, A.; AghaKouchak, A.; Nakhjiri, N.; Stewardson, M.J.; Peel, M.C.; Phillips, T.J.; Wada, Y.; Ravalico, J.K. Compounding Impacts of Human-Induced Water Stress and Climate Change on Water Availability. Sci. Rep. 2017, 7, 1-9. [CrossRef]

7. Tollefson, J. IPCC says limiting global warming to $1.5^{\circ} \mathrm{C}$ will require drastic action. Nature 2018, 562, 172-173. [CrossRef]

8. De Wit, M.; Faaij, A. European biomass resource potential and costs. Biomass Bioenergy 2010, 34, 188-202. [CrossRef]

9. Williams, A.; Jones, J.M.; Ma, L.; Pourkashanian, M. Pollutants from the combustion of solid biomass fuels. Prog. Energy Combust. Sci. 2012, 38, 113-137. [CrossRef]

10. Zhang, Y.H.P. Reviving the carbohydrate economy via multi-product lignocellulose biorefineries. J. Ind. Microbiol. Biotechnol. 2008, 35, 367-375. [CrossRef]

11. Limayem, A.; Ricke, S.C. Lignocellulosic biomass for bioethanol production: Current perspectives, potential issues and future prospects. Prog. Energy Combust. Sci. 2012, 38, 449-467. [CrossRef]

12. Pettersen, R.C. The chemical composition of wood. Chem. Solid Wood 1984, 207, 57-126.

13. Badger, P.C. Trends in New Crops and New Uses; ASHS Press: Alexandria, VA, USA, 2002.

14. Payen, A. Mémoire sur la composition du tissu propre des plantes et du ligneux. Comptes Rendus 1838, 7, 1052-1056.

15. Onwukamike, K.N.; Grelier, S.; Grau, E.; Cramail, H.; Meier, M.A. Critical review on sustainable homogeneous cellulose modification: Why renewability is not enough. ACS Sustain. Chem. Eng. 2018, 7, 1826-1840. [CrossRef]

16. Badger, P. Ethanol from Cellulose: A General Review. Trends new Crop. New Uses 17-21. 2002. Available online: http://large. stanford.edu/publications/coal/references/docs/badger.pdf (accessed on 11 August 2021).

17. Sarker, T.R.; Pattnaik, F.; Nanda, S.; Dalai, A.K.; Meda, V.; Naik, S. Hydrothermal pretreatment technologies for lignocellulosic biomass: A review of steam explosion and subcritical water hydrolysis. Chemosphere 2021, 284, 131372. [CrossRef] [PubMed] 
18. Chen, P.; Shrotri, A.; Fukuoka, A. Synthesis of cello-oligosaccharides by depolymerization of cellulose: A review. Appl. Catal. A Gen. 2021, 621, 118177. [CrossRef]

19. Pirich, C.L.; Picheth, G.F.; Fontes, A.M.; Delgado-Aguilar, M.; Ramos, L.P. Disruptive enzyme-based strategies to isolate nanocelluloses: A review. Cellulose 2020, 27, 5457-5475. [CrossRef]

20. Yin, S.; Tan, Z. Hydrothermal liquefaction of cellulose to bio-oil under acidic, neutral and alkaline conditions. Appl. Energy 2012, 92, 234-239. [CrossRef]

21. Pavasars, I.; Hagberg, J.; Borén, H.; Allard, B. Alkaline degradation of cellulose: Mechanisms and kinetics. J. Polym. Environ. 2003, 11, 39-47. [CrossRef]

22. Huang, Y.-B.; Fu, Y. Hydrolysis of cellulose to glucose by solid acid catalysts. Green Chem. 2013, 15, 1095-1111. [CrossRef]

23. Sun, Y.; Cheng, J. Hydrolysis of lignocellulosic materials for ethanol production: A review. Bioresour. Technol. 2002, 83, 1-11. [CrossRef]

24. Orozco, A.; Ahmad, M.; Rooney, D.; Walker, G. Dilute acid hydrolysis of cellulose and cellulosic bio-waste using a microwave reactor system. Process Saf. Environ. Prot. 2007, 85, 446-449. [CrossRef]

25. Iranmahboob, J.; Nadim, F.; Monemi, S. Optimizing acid-hydrolysis: A critical step for production of ethanol from mixed wood chips. Biomass Bioenergy 2002, 22, 401-404. [CrossRef]

26. Hou, C.; Liu, H.; Mohammad, F.B. Preparation of ordered mesoporous F-H2Ti3O7 nanosheets using orthorhombic HTiOF3 as a precursor and their highly efficient degradation of tetracycline hydrochloride under simulated sunlight. J. Solid State Chem. 2021, 300, 122288. [CrossRef]

27. Hou, C.; Liu, H.; Li, Y. The preparation of three-dimensional flower-like TiO2/TiOF2photocatalyst and its efficient degradation of tetracycline hydrochloride. RSC Adv. 2021, 11, 14957-14969. [CrossRef]

28. Zhao, H.; Lu, D.; Wang, J.; Tu, W.; Wu, D.; Koh, S.W.; Gao, P.; Xu, Z.J.; Deng, S.; Zhou, Y.; et al. Raw biomass electroreforming coupled to green hydrogen generation. Nat. Commun. 2021, 12, 1-10. [CrossRef] [PubMed]

29. Turner, J.A. Sustainable hydrogen production. Science 2004, 305, 972-974. [CrossRef]

30. Parthasarathy, P.; Narayanan, K.S. Hydrogen production from steam gasification of biomass: Influence of process parameters on hydrogen yield-A review. Renew. Energy 2014, 66, 570-579. [CrossRef]

31. Isogai, A.; Atalla, R.H. Dissolution of cellulose in aqueous NaOH solutions. Cellulose 1998, 5, 309-319. [CrossRef]

32. Yan, L.; Qi, X. Degradation of cellulose to organic acids in its homogeneous alkaline aqueous solution. ACS Sustain. Chem. Eng. 2014, 2, 897-901. [CrossRef]

33. Moon, R.J.; Martini, A.; Nairn, J.; Simonsen, J.; Youngblood, J. Cellulose nanomaterials review: Structure, properties and nanocomposites. Chem. Soc. Rev. 2011, 40, 3941-3994. [CrossRef]

34. Sugano, Y.; Vestergaard, M.; Yoshikawa, H.; Saito, M.; Tamiya, E. Direct Electrochemical Oxidation of Cellulose: A Cellulose-Based Fuel Cell System. Electroanalysis 2010, 22, 1688-1694. [CrossRef]

35. Sugano, Y.; Latonen, R.-M.; Akieh-Pirkanniemi, M.; Bobacka, J.; Ivaska, A. Electrocatalytic Oxidation of Cellulose at a Gold Electrode. ChemSusChem 2014, 7, 2240-2247. [CrossRef]

36. Xiao, H.; Wu, M.; Zhao, G. Electrocatalytic oxidation of cellulose to gluconate on carbon aerogel supported gold nanoparticles anode in alkaline medium. Catalysts 2015, 6, 1-10. [CrossRef]

37. Tan, X.; Deng, W.; Liu, M.; Zhang, Q.; Wang, Y. Carbon nanotube-supported gold nanoparticles as efficient catalysts for selective oxidation of cellobiose into gluconic acid in aqueous medium. Chem. Commun. 2009, 46, 7179-7181. [CrossRef] [PubMed]

38. An, D.; Ye, A.; Deng, W.; Zhang, Q.; Wang, Y. Selective Conversion of Cellobiose and Cellulose into Gluconic Acid in Water in the Presence of Oxygen, Catalyzed by Polyoxometalate-Supported Gold Nanoparticles. Chem. A Eur. J. 2012, 18, $2938-2947$. [CrossRef] [PubMed]

39. Wu, M.; Jin, Y.; Zhao, G.; Li, M.; Li, D. Electrosorption-promoted photodegradation of opaque wastewater on a novel TiO2/carbon aerogel electrode. Environ. Sci. Technol. 2010, 44, 1780-1785. [CrossRef]

40. Ma, C.; Xue, W.; Li, J.; Xing, W.; Hao, Z. Mesoporous carbon-confined Au catalysts with superior activity for selective oxidation of glucose to gluconic acid. Green Chem. 2013, 15, 1035-1041. [CrossRef]

41. Sugano, Y.; Kumar, N.; Peurla, M.; Roine, J.; Aho, A.; Bobacka, J.; Mikkola, J.P. Specific Electrocatalytic Oxidation of Cellulose at Carbon Electrodes Modified by Gold Nanoparticles. ChemCatChem 2016, 8, 2401-2405. [CrossRef]

42. Meng, D.; Li, G.; Liu, Z.; Yang, F. Study of depolymerization of cotton cellulose by $\mathrm{Pb} / \mathrm{PbO} 2$ anode electrochemical catalysis in sulfuric acid solution. Polym. Degrad. Stab. 2011, 96, 1173-1178. [CrossRef]

43. Domb, A.J.; Kost, J.; Wiseman, D. Handbook of Biodegradable Polymers; CRC Press: Boca Raton, FL, USA, 1998 ; Volume 7.

44. Brown, H.T. XX-On the electrolysis of sugar solutions. (Preliminary notice). J. Chem. Soc. 1872, 25, 578-579. [CrossRef]

45. Zółtaszek, R.; Hanausek, M.; Kiliańska, Z.M.; Walaszek, Z. The biological role of D-glucaric acid and its derivatives: Potential use in medicine. Postepy Hig. Med. Dosw (Online) 2008, 62, 451-462.

46. Werpy, T.; Petersen, G. Top Value Added Chemicals From Biomass: Volume I-Results of Screening For Potential Candidates From Sugars and Synthesis Gas; National Renewable Energy Lab.: Golden, CO, USA, 2004. [CrossRef]

47. Mehtiö, T.; Toivari, M.; Wiebe, M.G.; Harlin, A.; Penttilä, M.; Koivula, A. Production and applications of carbohydrate-derived sugar acids as generic biobased chemicals. Crit. Rev. Biotechnol. 2016, 36, 904-916. [CrossRef] [PubMed]

48. Smith, T.N.; Hash, K.; Davey, C.-L.; Mills, H.; Williams, H.; Kiely, D.E. Modifications in the nitric acid oxidation of D-glucose. Carbohydr. Res. 2012, 350, 6-13. [CrossRef] [PubMed] 
49. Hou, W.; Bao, J. Evaluation of cement retarding performance of cellulosic sugar acids. Constr. Build. Mater. 2019, $202,522-527$. [CrossRef]

50. Ramachandran, S.; Fontanille, P.; Pandey, A.; Larroche, C. Gluconic acid: Properties, applications and microbial production. Food Technol. Biotechnol. 2006, 44, 2.

51. Hayes, G.C.; Becer, C.R. Levulinic acid: A sustainable platform chemical for novel polymer architectures. Polym. Chem. 2020, 11, 4068-4077. [CrossRef]

52. Bozell, J.J.; Moens, L.; Elliott, D.C.; Wang, Y.; Neuenscwander, G.G.; Fitzpatrick, S.W.; Bilski, R.J.; Jarnefeld, J.L. Production of levulinic acid and use as a platform chemical for derived products. Resour. Conserv. Recycl. 2000, 28, 227-239. [CrossRef]

53. Lewkowski, J. Synthesis, chemistry and applications of 5-hydroxymethylfurfural and its derivatives. Arkivoc 2001, 1, 17-54. [CrossRef]

54. Bin, D.; Wang, H.; Li, J.; Wang, H.; Yin, Z.; Kang, J.; He, B.; Li, Z. Controllable oxidation of glucose to gluconic acid and glucaric acid using an electrocatalytic reactor. Electrochim. Acta 2014, 130, 170-178. [CrossRef]

55. Solmi, S.; Morreale, C.; Ospitali, F.; Agnoli, S.; Cavani, F. Oxidation of d-Glucose to Glucaric Acid Using Au/C Catalysts. Chem CatChem 2017, 9, 2797-2806. [CrossRef]

56. Moggia, G.; Kenis, T.; Daems, N.; Breugelmans, T. Electrochemical Oxidation of d-Glucose in Alkaline Medium: Impact of Oxidation Potential and Chemical Side Reactions on the Selectivity to d-Gluconic and d-Glucaric Acid. ChemElectroChem 2020, 7 , 86-95. [CrossRef]

57. Marianou, A.A.; Michailof, C.M.; Pineda, A.; Iliopoulou, E.F.; Triantafyllidis, K.S.; Lappas, A.A. Glucose to fructose isomerization in aqueous media over homogeneous and heterogeneous catalysts. ChemCatChem 2016, 8, 1100-1110. [CrossRef]

58. Moggia, G.; Schalck, J.; Daems, N.; Breugelmans, T. Two-steps synthesis of D-glucaric acid via D-gluconic acid by electrocatalytic oxidation of D-glucose on gold electrode: Influence of operational parameters. Electrochim. Acta 2021, 374, 137852. [CrossRef]

59. Tominaga, M.; Shimazoe, T.; Nagashima, M.; Taniguchi, I. Electrocatalytic oxidation of glucose at gold nanoparticle-modified carbon electrodes in alkaline and neutral solutions. Electrochem. Commun. 2005, 7, 189-193. [CrossRef]

60. Liu, W.J.; Xu, Z.; Zhao, D.; Pan, X.Q.; Li, H.C.; Hu, X.; Fan, Z.; Wang, W.; Zhao, G.; Yu, H.Q. Efficient electrochemical production of glucaric acid and $\mathrm{H} 2$ via glucose electrolysis. Nat. Commun. 2020, 11, 1-11. [CrossRef]

61. Neha, N.; Kouamé, B.S.R.; Rafaïdeen, T.; Baranton, S.; Coutanceau, C. Remarkably Efficient Carbon-Supported Nanostructured Platinum-Bismuth Catalysts for the Selective Electrooxidation of Glucose and Methyl-Glucoside. Electrocatalysis 2021, 12, 1-14. [CrossRef]

62. Rao, J.R.; Richter, G.J.; von Sturm, F.; Weidlich, E. The performance of glucose electrodes and the characteristics of different biofuel cell constructions. Bioelectrochem. Bioenerg. 1976, 3, 139-150. [CrossRef]

63. Poulopoulou, N.; Smyrnioti, D.; Nikolaidis, G.N.; Tsitsimaka, I.; Christodoulou, E.; Bikiaris, D.N.; Charitopoulou, M.A.; Achilias, D.S.; Kapnisti, M.; Papageorgiou, G.Z. Sustainable plastics from biomass: Blends of polyesters based on 2, 5-furandicarboxylic acid. Polymers 2020, 12, 225. [CrossRef]

64. Smith, P.B. Bio-based sources for terephthalic acid. In Green Polymer Chemistry: Biobased Materials and Biocatalysis; ACS Publications: Washington, DC, USA, 2015; pp. 453-469.

65. Rajendran, S.; Raghunathan, R.; Hevus, I.; Krishnan, R.; Ugrinov, A.; Sibi, M.P.; Webster, D.C.; Sivaguru, J. Programmed photodegradation of polymeric/oligomeric materials derived from renewable bioresources. Angew. Chemie 2015, 127, 1175-1179. [CrossRef]

66. Liu, W.J.; Dang, L.; Xu, Z.; Yu, H.Q.; Jin, S.; Huber, G.W. Electrochemical oxidation of 5-hydroxymethylfurfural with NiFe layered double hydroxide (LDH) nanosheet catalysts. ACS Catal. 2018, 8, 5533-5541. [CrossRef]

67. Weidner, J.; Barwe, S.; Sliozberg, K.; Piontek, S.; Masa, J.; Apfel, U.P.; Schuhmann, W. Cobalt-metalloid alloys for electrochemical oxidation of 5-hydroxymethylfurfural as an alternative anode reaction in lieu of oxygen evolution during water splitting. Beilstein J. Org. Chem. 2018, 14, 1436-1445. [CrossRef] [PubMed]

68. Nam, D.H.; Taitt, B.J.; Choi, K.S. Copper-Based Catalytic Anodes to Produce 2,5-Furandicarboxylic Acid, a Biomass-Derived Alternative to Terephthalic Acid. ACS Catal. 2018, 8, 1197-1206. [CrossRef]

69. Taitt, B.J.; Nam, D.H.; Choi, K.S. A Comparative Study of Nickel, Cobalt, and Iron Oxyhydroxide Anodes for the Electrochemical Oxidation of 5-Hydroxymethylfurfural to 2,5-Furandicarboxylic Acid. ACS Catal. 2019, 9, 660-670. [CrossRef]

70. Kang, M.J.; Park, H.; Jegal, J.; Hwang, S.Y.; Kang, Y.S.; Cha, H.G. Electrocatalysis of 5-hydroxymethylfurfural at cobalt based spinel catalysts with filamentous nanoarchitecture in alkaline media. Appl. Catal. B Environ. 2019, 242, 85-91. [CrossRef]

71. Cai, M.; Ding, S.; Gibbons, B.; Yang, X.; Kessinger, M.C.; Morris, A.J. Nickel(ii)-modified covalent-organic framework film for electrocatalytic oxidation of 5-hydroxymethylfurfural (HMF). Chem. Commun. 2020, 56, 14361-14364. [CrossRef]

72. Huang, X.; Song, J.; Hua, M.; Xie, Z.; Liu, S.; Wu, T.; Yang, G.; Han, B. Enhancing the electrocatalytic activity of CoO for the oxidation of 5-hydroxymethylfurfural by introducing oxygen vacancies. Green Chem. 2020, 22, 843-849. [CrossRef]

73. Hu, K.; Zhang, M.; Liu, B.; Yang, Z.; Li, R.; Yan, K. Efficient electrochemical oxidation of 5-hydroxymethylfurfural to 2,5furandicarboxylic acid using the facilely synthesized 3D porous WO3/Ni electrode. Mol. Catal. 2021, 504, 111459. [CrossRef]

74. Wang, W.; Kong, F.; Zhang, Z.; Yang, L.; Wang, M. Sulfidation of nickel foam with enhanced electrocatalytic oxidation of 5-hydroxymethylfurfural to 2,5-furandicarboxylic acid. Dalt. Trans. 2021, 50, 10922-10927. [CrossRef] [PubMed]

75. Kubota, S.R.; Choi, K.S. Electrochemical oxidation of 5-hydroxymethylfurfural to 2,5-furandicarboxylic acid (Fdca) in acidic media enabling spontaneous fdca separation. ChemSusChem 2018, 11, 2138-2145. [CrossRef] 
76. Santos, T.R.D.; Nilges, P.; Sauter, W.; Harnisch, F.; Schröder, U. Electrochemistry for the generation of renewable chemicals: Electrochemical conversion of levulinic acid. RSC Adv. 2015, 5, 26634-26643. [CrossRef]

77. Nilges, P.; Santos, T.R.D.; Harnisch, F.; Schröder, U. Electrochemistry for biofuel generation: Electrochemical conversion of levulinic acid to octane. Energy Environ. Sci. 2012, 5, 5231-5235. [CrossRef]

78. Yazdani, S.S.; Gonzalez, R. Anaerobic fermentation of glycerol: A path to economic viability for the biofuels industry. Curr. Opin. Biotechnol. 2007, 18, 213-219. [CrossRef] [PubMed]

79. Simões, M.; Baranton, S.; Coutanceau, C. Electrochemical valorisation of glycerol. ChemSusChem 2012, 5, 2106-2124. [CrossRef]

80. Du, L.; Shao, Y.; Sun, J.; Yin, G.; Du, C.; Wang, Y. Electrocatalytic valorisation of biomass derived chemicals. Catal. Sci. Technol. 2018, 8, 3216-3232. [CrossRef]

81. Rahim, S.A.N.M.; Lee, C.S.; Abnisa, F.; Aroua, M.K.; Daud, W.A.W.; Cognet, P.; Pérès, Y. A review of recent developments on kinetics parameters for glycerol electrochemical conversion-A by-product of biodiesel. Sci. Total Environ. 2020, 705, 135137. [CrossRef] [PubMed]

82. Liu, C.; Hirohara, M.; Maekawa, T.; Chang, R.; Hayashi, T.; Chiang, C.Y. Selective electro-oxidation of glycerol to dihydroxyacetone by a non-precious electrocatalyst-CuO. Appl. Catal. B Environ. 2020, 265, 118543. [CrossRef]

83. Katryniok, B.; Kimura, H.; Skrzyńska, E.; Girardon, J.S.; Fongarland, P.; Capron, M.; Ducoulombier, R.; Mimura, N.; Paul, S.; Dumeignil, F. Selective catalytic oxidation of glycerol: Perspectives for high value chemicals. Green Chem. 2011, 13, 1960-1979. [CrossRef]

84. Vo, T.-G.; Ho, P.-Y.; Chiang, C.-Y. Operando mechanistic studies of selective oxidation of glycerol to dihydroxyacetone over amorphous cobalt oxide. Appl. Catal. B Environ. 2021, 300, 120723. [CrossRef]

85. Kwon, Y.; de Jong, E.; van der Waal, J.K.; Koper, M.T.M. Selective electrocatalytic oxidation of sorbitol to fructose and sorbose. ChemSusChem 2015, 8, 970-973. [CrossRef]

86. Döbereiner, J.W. Ueber die medicinische und chemische Anwendung und die vortheilhafte Darstellung der Ameisensäure. Ann. Pharm. 1832, 3, 141-146. [CrossRef]

87. Nilges, P.; Schröder, U. Electrochemistry for biofuel generation: Production of furans by electrocatalytic hydrogenation of furfurals. Energy Environ. Sci. 2013, 6, 2925-2931. [CrossRef]

88. Kubota, S.R.; Choi, K.S. Electrochemical Valorization of Furfural to Maleic Acid. ACS Sustain. Chem. Eng. 2018, 6, 9596-9600. [CrossRef]

89. Román, A.M.; Agrawal, N.; Hasse, J.C.; Janik, M.J.; Medlin, J.W.; Holewinski, A. Electro-oxidation of furfural on gold is limited by furoate self-assembly. J. Catal. 2020, 391, 327-335. [CrossRef]

90. Yang, F.; Zhang, Q.; Fan, H.X.; Li, Y.; Li, G. Electrochemical control of the conversion of cellulose oligosaccharides into glucose. J. Ind. Eng. Chem. 2014, 20, 3487-3492. [CrossRef]

91. Kwon, Y.; de Jong, E.; Raoufmoghaddam, S.; Koper, M.T.M. Electrocatalytic Hydrogenation of 5-Hydroxymethylfurfural in the Absence and Presence of Glucose. ChemSusChem 2013, 6, 1659-1667. [CrossRef]

92. Kwon, Y.; Birdja, Y.Y.; Raoufmoghaddam, S.; Koper, M.T.M. Electrocatalytic Hydrogenation of 5-Hydroxymethylfurfural in Acidic Solution. ChemSusChem 2015, 8, 1745-1751. [CrossRef] [PubMed]

93. Tian, G.; Daniel, R.; Li, H.; Xu, H.; Shuai, S.; Richards, P. Laminar burning velocities of 2, 5-dimethylfuran compared with ethanol and gasoline. Energy Fuels 2010, 24, 3898-3905. [CrossRef]

94. Moreau, C.; Belgacem, M.N.; Gandini, A. Recent catalytic advances in the chemistry of substituted furans from carbohydrates and in the ensuing polymers. Top. Catal. 2004, 27, 11-30. [CrossRef]

95. Esteves, L.M.; Brijaldo, M.H.; Oliveira, E.G.; Martinez, J.J.; Rojas, H.; Caytuero, A.; Passos, F.B. Effect of support on selective 5-hydroxymethylfurfural hydrogenation towards 2, 5-dimethylfuran over copper catalysts. Fuel 2020, 270, 117524. [CrossRef]

96. Chadderdon, X.H.; Chadderdon, D.J.; Pfennig, T.; Shanks, B.H.; Li, W. Paired electrocatalytic hydrogenation and oxidation of 5-(hydroxymethyl)furfural for efficient production of biomass-derived monomers. Green Chem. 2019, 21, 6210-6219. [CrossRef]

97. Zhang, Y.R.; Wang, B.X.; Qin, L.; Li, Q.; Fan, Y.M. A non-noble bimetallic alloy in the highly selective electrochemical synthesis of the biofuel 2,5-dimethylfuran from 5-hydroxymethylfurfural. Green Chem. 2019, 21, 1108-1113. [CrossRef]

98. Liu, H.; Lee, T.H.; Chen, Y.; Cochran, E.W.; Li, W. Paired electrolysis of 5-(hydroxymethyl)furfural in flow cells with a highperformance oxide-derived silver cathode. Green Chem. 2021, 23, 5056-5063. [CrossRef]

99. Robertson, G.P.; Hamilton, S.K.; Barham, B.L.; Dale, B.E.; Izaurralde, R.C.; Jackson, R.D.; Landisscott, D.A.; Swinton, M.; Thelen, K.D.; Tiedje, J.M. Cellulosic biofuel contributions to a sustainable energy future: Choices and outcomes. Science 2017, $356,6345$. [CrossRef] [PubMed]

100. Bessou, C.; Ferchaud, F.; Gabrielle, B.; Mary, B. Biofuels, greenhouse gases and climate change. Sustain. Agric. $2011,2,365-468$.

101. Lange, J.P.; Price, R.; Ayoub, P.M.; Louis, J.; Petrus, L.; Clarke, L.; Gosselink, H. Valeric biofuels: A platform of cellulosic transportation fuels. Angew. Chem. Int. Ed. 2010, 49, 4479-4483. [CrossRef] [PubMed]

102. Serrano-Ruiz, J.C.; Wang, D.; Dumesic, J.A. Catalytic upgrading of levulinic acid to 5-nonanone. Green Chem. 2010, $12,574-577$. [CrossRef]

103. Gong, Y.; Lin, L.; Yan, Z. Catalytic hydrogenation and oxidation of biomass-derived levulinic acid. BioResources 2011, 6, 686-699. [CrossRef]

104. Xin, L.; Zhang, Z.; Qi, J.; Chadderdon, D.J.; Qiu, Y.; Warsko, K.M.; Li, W. Electricity storage in biofuels: Selective electrocatalytic reduction of levulinic acid to valeric acid or $\gamma$-valerolactone. ChemSusChem 2013, 6, 674-686. [CrossRef] 
105. Bond, J.Q.; Alonso, D.M.; Wang, D.; West, R.M.; Dumesic, J.A. Integrated catalytic conversion of $\gamma$-valerolactone to liquid alkenes for transportation fuels. Science 2010, 327, 1110-1114. [CrossRef]

106. Horváth, I.T.; Mehdi, H.; Fábos, V.; Boda, L.; Mika, L.T. $\gamma$-Valerolactone-a sustainable liquid for energy and carbon-based chemicals. Green Chem. 2008, 10, 238-242. [CrossRef]

107. Du, Y.; Chen, X.; Qi, J.; Wang, P.; Liang, C. Synthesis of valeric acid by selective electrocatalytic hydrogenation of biomass-derived levulinic acid. Catalysts 2020, 10, 692. [CrossRef]

108. Kurig, N.; Meyers, J.; Holzhaüser, F.J.; Palkovits, S.; Palkovits, R. (Non-)Kolbe Chemistry Going with the Flow: The Continuous Electrolysis of Biogenic Acids. ACS Sustain. Chem. Eng. 2021, 9, 1229-1234. [CrossRef]

109. Du, P.; Zhang, J.; Liu, Y.; Huang, M. Hydrogen generation from catalytic glucose oxidation by Fe-based electrocatalysts Electrochem. Commun. 2017, 83, 11-15. [CrossRef]

110. Rafaïdeen, T.; Baranton, S.; Coutanceau, C. Highly efficient and selective electrooxidation of glucose and xylose in alkaline medium at carbon supported alloyed PdAu nanocatalysts. Appl. Catal. B Environ. 2019, 243, 641-656. [CrossRef]

111. Rafaïdeen, T.; Neha, N.; Kouamé, B.R.S.; Baranton, S.; Coutanceau, C. Electroreforming of Glucose and Xylose in Alkaline Medium at Carbon Supported Alloyed Pd3Au7 Nanocatalysts: Effect of Aldose Concentration and Electrolysis Cell Voltage. Clean Technol. 2020, 2, 13. [CrossRef]

112. Lin, C.; Zhang, P.; Wang, S.; Zhou, Q.; Na, B.; Li, H.; Tian, J.; Zhang, Y.; Deng, C.; Zhang, L. Engineered porous Co-Ni alloy on carbon cloth as an efficient bifunctional electrocatalyst for glucose electrolysis in alkaline environment. J. Alloys Compd. 2020, 823, 153784. [CrossRef]

113. Lin, C.; Li, H.; Zhang, P.; Deng, C.; Meng, L.; Zhou, Q.; Wang, S.; Wu, J.; Liu, C.; Qian, Y. Boosting water electrolysis with anodic glucose oxidation reaction over engineered cobalt nickel hydroxide nanosheet on carbon cloth. J. Electroanal. Chem. 2020, 861, 113946. [CrossRef]

114. Liu, X.; Cai, P.; Wang, G.; Wen, Z. Nickel doped MoS2 nanoparticles as precious-metal free bifunctional electrocatalysts for glucose assisted electrolytic $\mathrm{H} 2$ generation. Int. J. Hydrogen Energy 2020, 45, 32940-32948. [CrossRef]

115. Zheng, D.; Li, J.; Ci, S.; Cai, P.; Ding, Y.; Zhang, M.; Wen, Z. Three-birds-with-one-stone electrolysis for energy-efficiency production of gluconate and hydrogen. Appl. Catal. B Environ. 2020, 277, 119178. [CrossRef]

116. Ding, Y.; Greiner, M.; Schlögl, R.; Heumann, S. A Metal-Free Electrode: From Biomass-Derived Carbon to Hydrogen. ChemSusChem 2020, 4064-4068. [CrossRef] [PubMed]

117. Yang, C.; Wang, C.; Zhou, L.; Duan, W.; Song, Y.; Zhang, F.; Zhang, J.; Bao, W.; Yuxuan, L.u.; Fu, F. Refining d-band center in Ni0.85Se by Mo doping: A strategy for boosting hydrogen generation via coupling electrocatalytic oxidation 5hydroxymethylfurfural. Chem. Eng. J. 2021, 422, 130125. [CrossRef]

118. Jiang, N.; You, B.; Boonstra, R.; Rodriguez, I.M.T.; Sun, Y. Integrating Electrocatalytic 5-Hydroxymethylfurfural Oxidation and Hydrogen Production via Co-P-Derived Electrocatalysts. ACS Energy Lett. 2016, 1, 386-390. [CrossRef]

119. Fan, K.; Chen, H.; Ji, Y.; Huang, H.; Claesson, P.M.; Daniel, Q.; Philippe, B.; Rensmo, H.; Li, F.; Sun, L.; et al. Nickel-vanadium monolayer double hydroxide for efficient electrochemical water oxidation. Nat. Commun. 2016, 7, 1-9. [CrossRef] [PubMed]

120. Liang, S.; Pan, L.; Thomas, T.; Zhu, B.; Chen, C.; Zhang, J.; Shen, H.; Liu, J.; Yang, M. Ni3N-V2O3 enables highly efficient 5-(Hydroxymethyl) furfural oxidation enabling membrane free hydrogen production. Chem. Eng. J. 2021, 415, 128864. [CrossRef] 